\title{
Study to Determine the Biological Feasibility of a New Fish Tagging System
}

\section{Annual Report}

\section{6 - 1987}

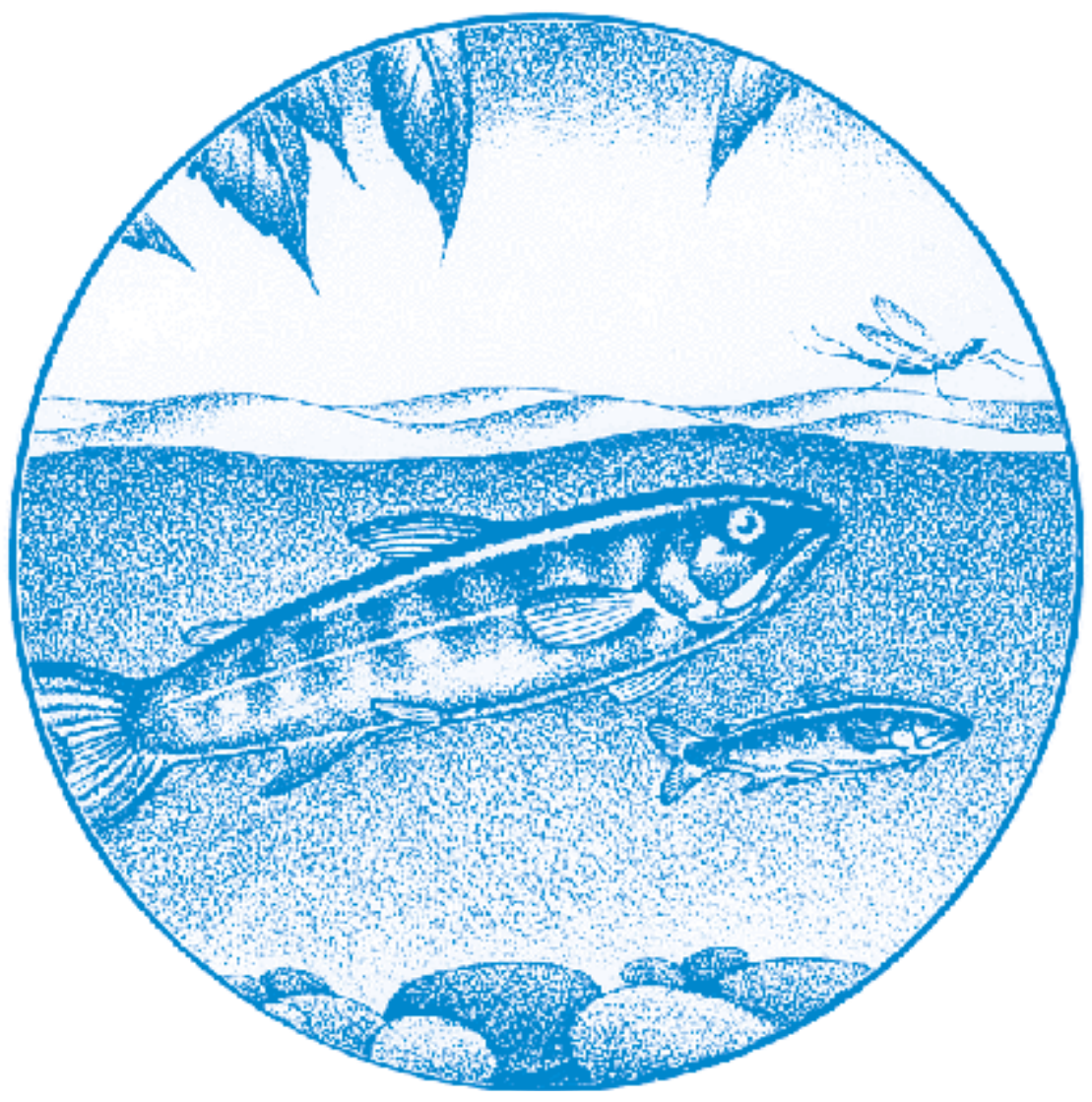

DOE/BP-11982-3

December 1987 
This Document should be cited as follows:

Prentice, Earl, C. McCutcheon, Thomas Flagg, "Study to Determine the Biological

Feasibility of a New Fish Tagging System", Project No. 1983-31900, 120 electronic

pages, (BPA Report DOE/BP-11982-3)

\author{
Bonneville Power Administration \\ P.O. Box 3621 \\ Portland, Oregon 97208
}

This report was funded by the Bonneville Power Administration (BPA), U.S. Department of Energy, as part of BPA's program to protect, mitigate, and enhance fish and wildlife affected by the development and operation of hydroelectric facilities on the Columbia River and its tributaries. The views in this report are the author's and do not necessarily represent the views of BPA. 
A STUDY TO DETERMINE THE BIOLOGICAL

FEASIBILITY OF A NEW FISH TAGGING SYSTEM, 1986-1987

Annual Report of Research

Prepared by

Earl F. Prentice

Thomas A. Flagg

and

Scott McCutcheon

Coastal Zone and Estuarine Studies, Division

Northwest and Alaska Fisheries Center

National Marine Fisheries Service

National Oceanic and Atmospheric Administration

2725 Montlake Boulevard East

Seattle, Washington 98112

\author{
Prepared for \\ Dale Johnson, Project Manager \\ U.S. Department of Energy \\ Bonneville Power Administration \\ Division of Fish and Wildlife \\ P.0. Box 3621 \\ Portland, Oregon 97208 \\ Project No. 83-319 \\ Contract No. DE-AI79-84BP11982
}


ABSTRACT

In 1983, a multi-year project to evaluate the technical and biological feasibility of adapting a new identification system to salmonids was established between the Bonneville Power Administration and the National Marine Fisheries Service. The system is based upon a miniaturized passive integrated transponder (PIT) tag. This report discusses the work completed in 1986 and is divided into laboratory studies, field studies, and systems development. All studies were conducted using a glass-encapsulated tag implanted into the body cavity of test fish via a 12-gauge hypodermic needle.

Laboratory studies with juvenile chinook salmon, Qncorhynchus tshawytscha, showed that retention of glass-encapsulated PIT tags was 99-100\% in fish weighing $3 \mathrm{~g}$ (mean weight) or larger. No adverse tissue response to the tag was noted. The survival of fish $5 \mathrm{~g}$ (mean weight) or larger was usually greater than 99\%. However, fish ranging in weight from 2 to $4 \mathrm{~g}$, or fish undergoing a physiological change such as smoltification may have a low mortality (usually less then 5.0\%) after tagging. The mortality rate in the smaller fish was dependent upon tagging skill whereas mortality in smolting fish seemed dependent upon the level of stress. Growth comparisons between tagged and control fish indicated PIT-tagged fish had a slightly depressed growth rate at some measurement periods. The operational life of glass-encapsulated PIT tags implanted in fish was good, with $100 \%$ of the tags operating after 401 days. No tags were rejected from the fish during the observation period. Additional information on the operational life of the tag is being obtained by holding tagged fish until they mature.

Tests to determine the effect of the PIT tag on certain behavioral/physiological responses were conducted in the laboratory with one size range of juvenile steelhead, Salvo gairdneri, and two size groups of 
juvenile fall chinook salmon. Results showed no significant effect of the tag on opercular rate, tail beat frequency, stamina, or post fatigue survival. Tests conducted at McNary Dam on outmigrant steelhead and fall and spring chinook salmon showed similar results.

Juvenile PIT tag monitoring systems were installed and tested at Lower Granite and McNary dams in the Columbia River Basin. The equipment is described and discussed. The tag monitoring equipment showed a high degree of reliability, efficiency, and accuracy. During the 6-month test, tag reading efficiency exceeded 95\%, with an accuracy rate of greater than 99\% for all equipment. Four minor equipment problems occurred during the testing period, all of which were corrected in the field.

Field studies were conducted at Lower Granite and McNary dams using spring and fall chinook salmon and steelhead to assess the performance of PIT-tagged fish in comparison to fish tagged or marked using traditional methods. No effect of the tag on survival was noted. Differences in survival were noted, however, between dam locations for all treatments. Comparisons of recovery rates of branded and PIT-tagged spring and fall chinook salmon released into McNary reservoir and recovered at the dam were made. A significantly higher number of PIT-tagged spring chinook salmon were recovered at the dam than branded fish whereas no differences in recovery rates were seen between treatments for fall chinook salmon. The PIT tag data were acquired with $90 \%$ fewer PIT-tagged fish released than branded fish. There was also a large reduction in the numbers of fish handled to obtain the data, 330:1 and 414:1 (brand vs PIT-tagged) for spring and fall chinook salmon, respectively. Groups of spring chinook salmon and steelhead were tagged and branded at Dworshak National Fish Hatchery and released into the Clearwater River. Tag 
recovery at Lower Granite and McNary dams showed that significantly higher numbers of PIT-tagged fish were recovered than branded fish.

Future work related to PIT tag systems development is described and discussed. 
Determination of Minimum Fish Size for Tagging $\ldots \ldots \ldots \ldots \ldots$

Introduction $\ldots \ldots \ldots \ldots \ldots \ldots \ldots \ldots \ldots \ldots \ldots \ldots \ldots \ldots \ldots \ldots \ldots \ldots \ldots \ldots$

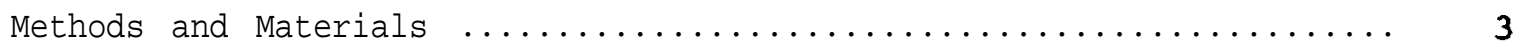

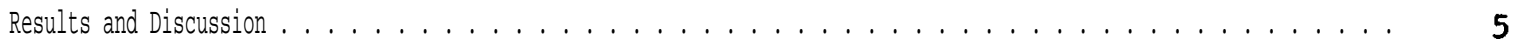

PIT Tag Longevity $\quad \ldots \ldots \ldots \ldots \ldots \ldots \ldots \ldots \ldots \ldots \ldots \ldots \ldots \ldots \ldots \ldots \ldots \ldots$

Introduction $\ldots \ldots \ldots \ldots \ldots \ldots \ldots \ldots \ldots \ldots \ldots \ldots \ldots \ldots \ldots \ldots \ldots \ldots$

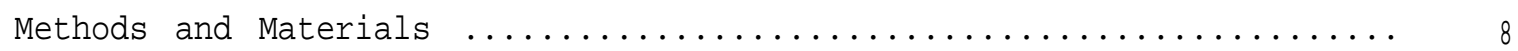

Results and Discussion $\ldots \ldots \ldots \ldots \ldots \ldots \ldots \ldots \ldots \ldots \ldots \ldots \ldots \ldots \ldots \ldots$

Effect of the PIT Tag on Swimming Ability of Hatchery

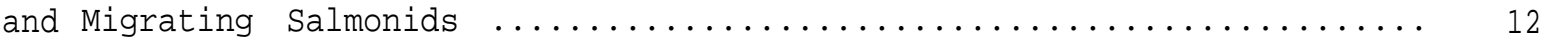

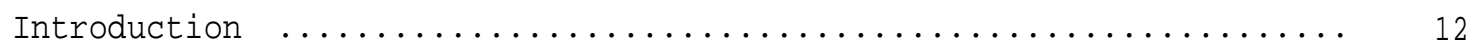

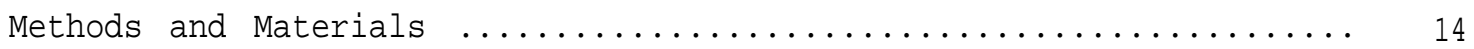

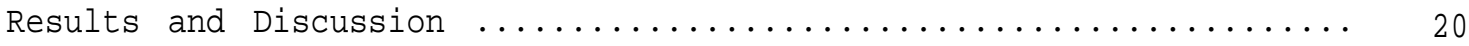

Conclusions and Recommendations . . . . . . . . . . . . . . . . . . . . . . . 32

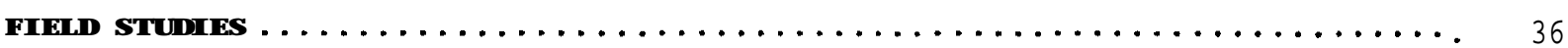

Reliability of Juvenile PIT Tag Monitors at

Lower Granite and McNary Dams ....................................

Introduction $\ldots \ldots \ldots \ldots \ldots \ldots \ldots \ldots$

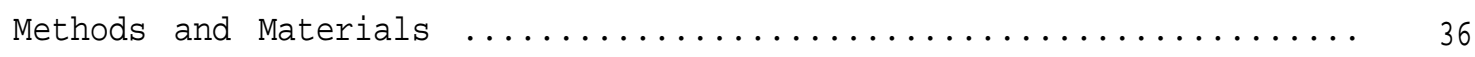

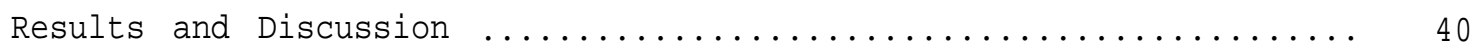


Tag Reading Efficiency of Juvenile PIT Tag

Monitors at Lower Granite and McNary Dams .................... 45

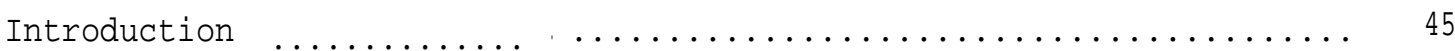

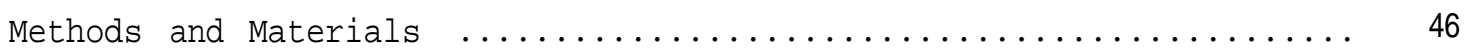

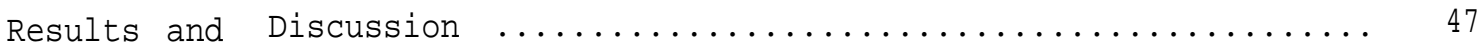

PIT-Tagged Fish Compared to Branded Fish from

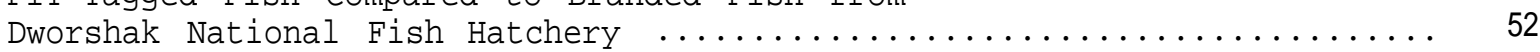

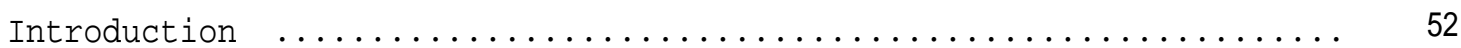

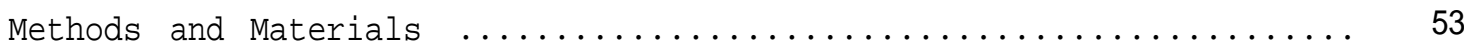

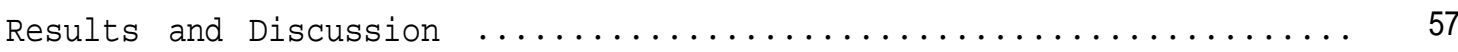

Spring Chinook salmon $\ldots \ldots \ldots \ldots \ldots \ldots \ldots \ldots \ldots \ldots \ldots \ldots \ldots \ldots \ldots \ldots \ldots$

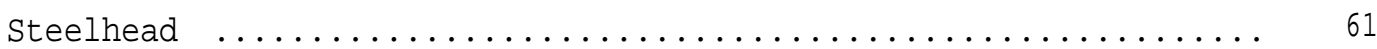

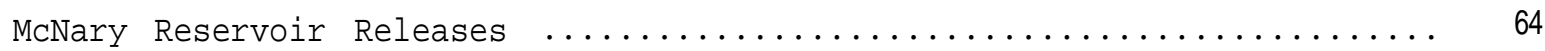

Introduction $\ldots \ldots \ldots \ldots \ldots \ldots \ldots \ldots \ldots \ldots \ldots \ldots \ldots \ldots \ldots \ldots \ldots \ldots \ldots \ldots$

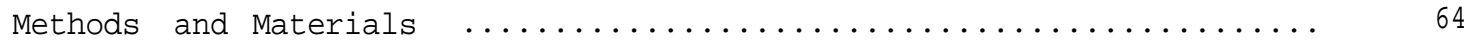

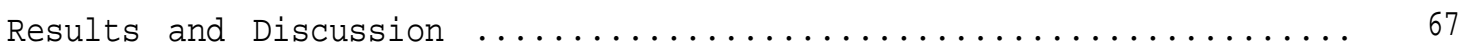

Yearling Chinook Salmon........................ 67

Underyearling Chinook Salmon $\ldots \ldots \ldots \ldots \ldots \ldots \ldots \ldots \ldots \ldots .68$

Comparison of the PIT Tag to Traditional Tagging and

Marking Methods ..................................... 70

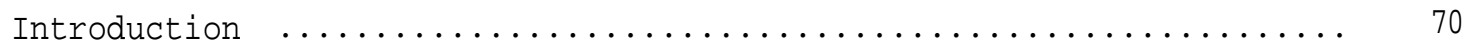

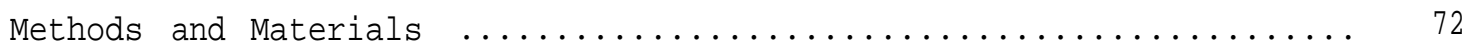

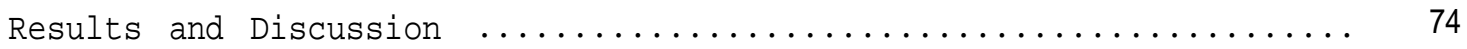

Conclusions and Recommendations ....................... 81 


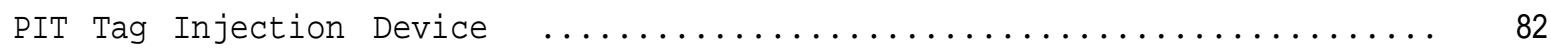

Introduction $\ldots \ldots \ldots \ldots \ldots \ldots \ldots \ldots \ldots \ldots \ldots \ldots \ldots \ldots \ldots \ldots \ldots \ldots \ldots$

Methods and Materials ........................... 83

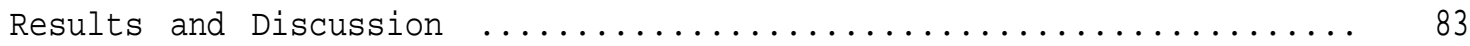

Quality Controi Monitor for Tagging . . . . . . . . . . . . . . . . . . . . 85

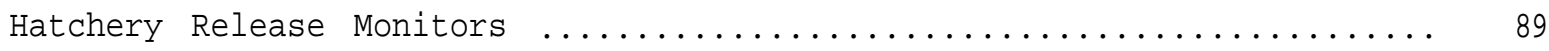

Introduction $\ldots \ldots \ldots \ldots \ldots \ldots \ldots \ldots \ldots \ldots \ldots \ldots \ldots \ldots$

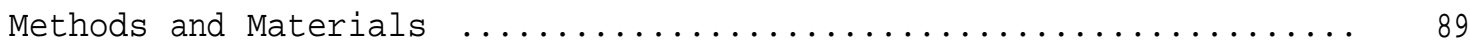

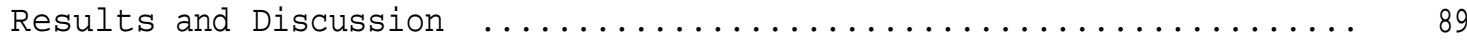

Design and Placement of Future Monitoring Systems ............... 90

Conclusions and Recommendations . . . . . . . . . . . . . . . . . . . . . . 91

ACKNONLEDGMENTS $\ldots \ldots \ldots \ldots \ldots$

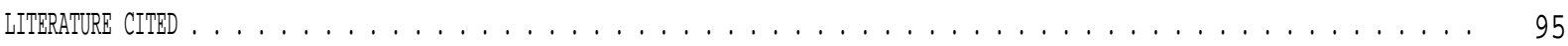

APPENDIX A-PIT-Tagging Technique . . . . . . . . . . . . . . . . . . . . 99

APPENDIX B--Histological Effects of PIT Tag . . . . . . . . . . . . . . . . . 103

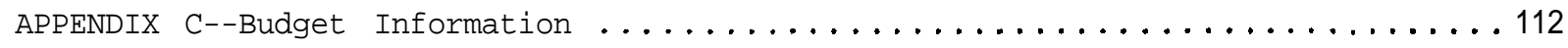


INTRODUCTION

In 1983, the National Marine Fisheries Service (NMFS) began a cooperative research program with the Bonneville Power Administration (BPA) to evaluate a new miniature identification system that could be used with salmonids. The system is referred to as a passive integrated transponder (PIT) tag. The first phase of evaluation, conducted in 1983, used non functional PIT tags (sham tags) to develop tagging techniques and to determine the most suitable anatomical area for tag placement in juvenile and adult salmon (Prentice et al. 1984). The second year's work (1984) involved preliminary tests to determine tissue response to the tag and the tag's effect on growth and survival. In addition, initial design and testing of tag detection equipment for use at various dams on the Columbia River system was began (Prentice et al. 1985).

In 1985, a concentrated effort was made to determine the effect of the tag on growth, survival, and behavior of salmon of various sizes. During this period, field tests were conducted at McNary and Bonneville dams on the Columbia River to evaluate PIT tag detection systems for juvenile and adult salmon. Tests also compared laboratory findings on the effect of the PIT tag to those obtained under field conditions (Prentice et al. 1986). All tests conducted in 1985 used a functional tag which had its electronics encapsulated in polypropylene (which was later found to be an unsatisfactory material because of sealing problems).

Research during 1986 was an extension of the 1985 laboratory and field work but used a new glass-encapsulated version of the PIT tag which eliminated the sealing problem. Field work was expanded to Lower Granite Dam on the Snake River and Dworshak National Fish Hatchery in Idaho. The prototype PIT tag 
monitoring system installed at McNary Dam in 1985 was replaced with an improved model. The monitoring system at each dam was evaluated using the techniques developed in 1985. Comparative work between laboratory and field studies were continued on an expanded scale. This report covers the results of the laboratory and field studies conducted in 1986 in addition to discussing future needs and systems development. For convenience, the 1986 report is divided into three parts: laboratory studies, field studies, and systems development,

\section{LABORATORY STUDIES}

Determination of Minimum Fish Size For Tagging

Introduction

PIT tag retention in juvenile fish has been evaluated since 1983 (Prentice et al. 1984, 1985, and 1986). These early studies, using the old style polypropylene-encapsulated PIT tag, revealed higher than acceptable tag rejection (4\% or greater) for fish under $8 \mathrm{~g}$. The authors suggest that rough edges on the polypropylene tag might exacerbate tag loss. In 1986, a glassencapsulation process was developed for the PIT tag that produced a smooth, biologically inert tag.

The objective of the present study was to evaluate the relationship between fish size at tagging and tag retention for the glass-encapsulated PIT tag. The criteria for successful tagging was $>95 \%$ tag retention for at least 134 days. In addition, comparisons were made between growth, survival, and tag retention of fish reared on pathogen free artesian well water and ambient surface river water. 
Methods and Materials

Juvenile fall chinook salmon, Oncorhynchus tshawytscha, were used for this study at the Big Beef Creek Research Station near Seabeck, Washington. Two separate populations were maintained in 2.4-m diameter tanks supplied with either constant temperature $\left(10^{\circ} \mathrm{C}\right)$ artesian well water or Big Beef Creek ambient temperature surface water. Standard husbandry practices were followed throughout the experiment, and all fish were fed ad libitum. Four test (PITtagged) groups and one control group were randomly selected from each main population (well or stream) through time covering a range of fish sizes from 3 to $10 \mathrm{~g}$ (Table 1). PIT- tagged groups were established on: V April (Test 1), 30 April (Test 2), 15 May (Test 3), and 5 June 1986 (Test 4). The control groups were set-up on 30 April 1986. Each lot of fish ( $=200$ to 203) were held in 1.2-m diameter tanks supplied with either running well or stream water as appropriate.

All tagged fish were hand injected with the PIT tag in a manner similar to that described in Appendix A. Control fish were handled but not tagged- Fifty fish in each replicate were weighed to the nearest $0.5 \mathrm{~g}$, and all fish were measured to the nearest $3.0 \mathrm{~mm}$ (fork length) at Day 0, on (or near) Days 45 and 90, and at termination (Day 134-139). Tag presence was confirmed for all tagged fish at each weighing and measuring period. Each test tank was examined for rejected tags at 1 to 3 -day intervals.

Growth data were analyzed using standard ANOVA techniques (Sokal and Rohlf 1981). Predictive sample reuse (PSR) techniques for categorical data, as described by Kappenman (1983), were used to determine interrelationships between size, tag retention, and survival. 
Table 1. - Inventory record for serial PI T tagging of fal I chl noob sal non to deternine mini mum size for tagging.

\begin{tabular}{|c|c|c|c|c|c|c|c|c|c|c|c|c|c|c|c|c|}
\hline \multirow{2}{*}{$\begin{array}{l}\text { Treat- } \\
\text { nebt }\end{array}$} & \multirow[b]{2}{*}{ Day } & \multirow[b]{2}{*}{ No. } & \multirow{2}{*}{$\begin{array}{l}\text { Surv- } \\
\text { vi val } \\
1 \%\end{array}$} & \multicolumn{2}{|c|}{$\begin{array}{r}\text { Wei ght } \\
\text { (g) }\end{array}$} & \multicolumn{2}{|c|}{$\begin{array}{c}\text { Length } \\
(\mathrm{mm}) \\
\end{array}$} & \multirow{2}{*}{$\begin{array}{c}\text { Tag } \\
\text { retenti on } \\
(\%)\end{array}$} & \multirow[b]{2}{*}{ Day } & \multirow[b]{2}{*}{ Nb. } & \multirow{2}{*}{$\begin{array}{c}\text { Surv- } \\
\text { vi val } \\
(\%)\end{array}$} & \multicolumn{2}{|c|}{$\begin{array}{c}\text { Wei ght } \\
\text { (g) }\end{array}$} & \multicolumn{2}{|c|}{$\begin{array}{c}\text { Length } \\
\text { (mm) }\end{array}$} & \multirow{2}{*}{$\begin{array}{c}\text { Tag } \\
\text { retent } i \text { on } \\
(\%)\end{array}$} \\
\hline & & & & Mean & $\overline{\text { SD }}$ & Mean & $\overline{\text { SD }}$ & & & & & Mean & SD & Mean & SD & \\
\hline
\end{tabular}

Peri od 2

Coservati on peri ods

\begin{tabular}{|c|c|c|c|c|c|c|c|c|}
\hline W-PIT - I & 0 & 201 & 100.0 & 3.2 & 0.5 & 66 & 3 & 100.0 \\
\hline S-PIT - I & 0 & 200 & 100.0 & 3.2 & 0.6 & 66 & 3 & 100.0 \\
\hline wGib - 2 & 0 & 202 & 100.0 & 4.9 & 1.1 & 77\# & 5 & $\cdots$ \\
\hline WPIT - 2 & 0 & 200 & 100.0 & 5. $1^{*}$ & 1.0 & 78*\# & 5 & 100.0 \\
\hline S-Con - 2 & 0 & 200 & 100.0 & $5.1 \#$ & 0.9 & 77 & 5 & $\ldots$ \\
\hline S-PIT - 2 & 0 & 200 & 100.0 & 4. $8^{*} \#$ & 1.0 & $77^{*}$ & 5 & 100.0 \\
\hline WPIT - 3 & 0 & 201 & 100.0 & 7.1 & 1.3 & $84 *$ & 5 & 100.0 \\
\hline S-PI T - 3 & 0 & 203 & 100.0 & 7.3 & 1.3 & $85^{*}$ & 5 & 100.0 \\
\hline WPIT - 4 & 0 & 200 & 100.0 & 9.7 & 1.7 & 99 & 6 & 100.0 \\
\hline S-PIT - 4 & 0 & 202 & 100.0 & 10.0 & 1.8 & 100 & 6 & 100.0 \\
\hline
\end{tabular}

Peri od 3

\begin{tabular}{|c|c|c|c|c|c|c|c|c|c|c|c|c|c|c|c|c|c|}
\hline WPI T & -1 & 98 & 200 & 99.5 & 13.8 & 2.1 & $106^{*}$ & 5 & 100.0 & 139 & 200 & 99.5 & 20.5 & 4. 0 & $121 \#$ & 6.3 & 100.0 \\
\hline S- PI T & -1 & 90 & 191 & 95.5 & 14.5 & 2.9 & $109 *$ & 6 & 99.0 & 139 & 190 & 95.0 & 21.1 & 3.7 & $122^{*}$ & 6.6 & 99.0 \\
\hline WCon & -2 & 90 & 202 & 100.0 & $15.8 \#$ & 3.0 & 109 & 7 & $\ldots$ & 135 & 202 & 100.0 & 24.9 & 4.4 & $125 \#$ & 8.1 & $\ldots$ \\
\hline WPI T & - 2 & 90 & 200 & 100.0 & 17. $2^{*} \#$ & 3. 3 & 109 & 7 & 100.0 & 135 & 200 & 100.0 & $27.4^{*}$ & 3.0 & $|3| * \#$ & 8.3 & 100.0 \\
\hline S- Con & - 2 & 90 & 199 & 99.5 & $17.2 \#$ & 3.1 & 112\# & 6 & $\ldots$ & 135 & 198 & 99.0 & 24.8 & 5.4 & 126 & 7.9 & $\ldots$ \\
\hline S-PIT & - 2 & 90 & 196 & 98.0 & 16. I *\# & 2.7 & 109\# & 6 & 100.0 & 135 & 196 & 98.0 & 23. $0^{*}$ & 3.7 & $127 *$ & 7.3 & 100.0 \\
\hline WPI T & - 3 & 91 & 201 & 100.0 & 20.2 & 4. 1 & 118 & 6 & 100.0 & 134 & 201 & 100.0 & 25. 9* & 4.4 & I 29* & 7.6 & 100.0 \\
\hline S-PI T & -3 & 91 & 200 & 98.5 & 18.6 & 2.3 & 117 & 6 & 100.0 & 134 & 193 & 95.0 & 29. 9* & 4.4 & $130^{*}$ & 7.8 & 100.0 \\
\hline WPI T & -4 & 97 & 196 & 98.0 & 23. 8* & 4. 3 & $126^{*}$ & 7 & 100.0 & 137 & 194 & 97.0 & 32.6 & 6.4 & 138 & 6.5 & 100.0 \\
\hline S- PI T & - 4 & 97 & 198 & 98.0 & $20.8^{*}$ & 3.7 & $123^{*}$ & 7 & 100.0 & 137 & 198 & 98.0 & 30.3 & 4.2 & 135 & 8.5 & 100.0 \\
\hline
\end{tabular}

Peri od 2

$\begin{array}{rrrrrrrr}49 & 201 & 99.5 & 7.8 & 1.2 & 88 & 4.3 & 100.0 \\ 49 & 193 & 96.5 & 8.1 & 1.2 & 88 & 4.8 & 99.0 \\ & & & & & & & \\ 48 & 202 & 100.0 & 10.7 & 2.2 & 95 \# & 5.7 & \ldots \ldots \\ 49 & 202 & 100.0 & 11.0 & 1.6 & 98 \# & 5.4 & 100.0 \\ 48 & \text { IVY } & 99.5 & 10.4 & 1.8 & 99 \# & 5.2 & \ldots \ldots \\ 49 & 196 & 98.0 & 10.6 & 1.4 & 97 \# & 4.7 & 100.0 \\ & & & & & & & \\ 55 & 201 & 100.0 & 14.0 & 2.5 & 104 & 5.0 & 100.0 \\ 55 & 198 & 97.5 & 13.0 & 2.1 & 104 & 5.6 & 100.0 \\ & & & & & & & \\ 49 & 198 & 99.0 & 16.3 & 2.9 & 112^{*} & 4.9 & 100.0 \\ 49 & 202 & 100.0 & 15.2 & 3.0 & 109 * & 5.7 & 100.0\end{array}$

Peri od 4

a $\mathbf{W}$ - uel I water rearing, $\mathrm{S}$ - stream water rearing. PIT = PIT tagged. Con - control. I - 4 i ndi cates sequenti al group nunber.

* = Si gni fi canti y different $(P<0, \infty)$ for treatnent vs treatnent compari sons.

\# = si gni ficantly different $(P \ll 05)$ for treatnent vs control compari sons. 
Results and Discussion

All data for the study are summarized in Tables 1 and 2 . The criterion for successful tag retention was $>95 \%$ for a minimum 134-day period. This criterion was achieved in all test groups, with tag retention ranging from 99-100\%. Of the 2,009 fish tagged during these experiments, only five (0.25\%) had non-functional tags. These tags were from the first production lot of glass tags, and the manufacturer took corrective action to improve reliability.

Growth comparisons indicated significant differences $(P<0.05)$ in length and weight at some sampling periods (Table 2). However, the differences were slight, had no observable pattern, and may have been related to differences in feed ration amount rather than treatment conditions. The PSR modeling supports this conclusion and indicates there is no association between fish size, water source, or presence of the PIT tag.

Overall survival of PIT-tagged fish (134 to 139 days) ranged from 97.0 to $100 \%$ in the well-water groups and from 95.0 to $98.0 \%$ in the stream-water groups and was comparable to controls at the one size range evaluated (Tables 1 and 2). Results of PSR analyses indicated the data best fit the model stating there was no association between water source and mortality, but there was an association between fish size and mortality. In other words, the model simply stated that mortality occurred within specific size groups, but it did not rank which group had the highest or lowest mortality.

Visual inspection of the data (Table 2) shows that a 5\% or less mortality occurred in the smallest size groups of fish in both well-and stream-water tests. Examination of mortalities for both initial well and stream groups showed perforation of the intestine as the cause of death. Foul- of the seven 
Table 2 .--Comparison of survival, growth, and PIT tag retention for the 1986 fall chinook salmon serial tagging study.

\begin{tabular}{lcccccc}
\hline & Number & Test & \multicolumn{2}{c}{ size } & & PIT tag \\
\cline { 5 - 6 } Test group/ & of & length & Start & End & Survival & retention \\
treatment a & fish & (days) & $(g)$ & $(g)$ & $\left(\frac{\circ}{0}\right)$ & $\left(\frac{\circ}{0}\right)$ \\
\hline
\end{tabular}

$\begin{array}{lllllr}\text { Control-well } & 202 & 135 & 4.9 & 24.9 & 100.0 \\ \text { Control-stream } & 200 & 135 & 5.1 & 24.8 & 99.0\end{array}$

PIT tageed:

$\begin{array}{lrrrrrr}\text { well-\#1 } & 201 & 139 & 3.2 & 20.5 & 99.5 & 100.0 \\ \text { well-\#2 } & 200 & 135 & 5.1 & 27.4 & 100.0 & 100.0 \\ \text { well-\#3 } & 201 & 134 & 7.1 & 25.9 & 100.0 & 100.0 \\ \text { well-\#4 } & 200 & 137 & 9.7 & 32.6 & 97.0 & 100.0 \\ & & & & & & \\ \text { stream-\#1 } & 200 & 139 & 3.2 & 21.1 & 95.0 & 99.0 \\ \text { stream-\#2 } & 200 & 135 & 4.8 & 22.6 & 98.0 & 100.0 \\ \text { stream-\#3 } & 203 & 134 & 7.3 & 29.9 & 95.0 & 100.0 \\ \text { stream-\#4 } & 202 & 137 & 10.0 & 30.3 & 98.0 & 100.0\end{array}$

a Well--indicates constant temperature $\left(10^{\circ} \mathrm{C}\right)$ pathogen free artesian well water rearing: stream--indicates ambient (9.30-14.4 $\left.{ }^{\circ} \mathrm{C}\right)$ temperature Big Beef Creek surface water rearing. 
mortalities in the first stream-water test group occurred within the first 2 days after tagging and were from the first $10 \mathrm{fish}$ tagged. This group of fish was the first to be tagged, and our tagging technique was not up to standard. The tagging technique was refined, and no problems with intestine perforation were observed in the other test groups.

Mortality in the larger size groups also was 5\% or less and occurred primarily in the stream-water held groups (Table 1). Visual examination indicated that these populat ions of fish were in various stages of smoltification. It is possible that exposure to pathogens in the stream water and smoltification status itself contributed to these mortalities. Reductions in immune response have been noted during smoltification (Maule et al. 1987) . The data suggest that if fish are less than $5 \mathrm{~g}$ (mean weight) or are undergoing smoltification when PIT-tagged, a low mortality (5.0\% or less) may occur.

Subsamples of these fish were examined to determine histological tissue reaction to the tag and to document tag location within the body cavity. A complete evaluation of these data is presented in Appendix B; however, no adverse tissue reaction was noted and tag location within the body cavity was consistent over time indicating the tag did not migrate from the implant area.

An important comparison in this study was the overall evaluation of the glass-encapsulated version of the PIT tag compared to the earlier polypropylene version. The present study showed that glass encapsulation overcame problems noted with the polypropylene version. The glass version proved to be highly reliable in tagging fish as small as $3 \mathrm{~g}$. Therefore, we feel confident that the glass encapsulated version of the PIT tag is developed to the point where it can be considered for use by managers and researchers in tagging studies. 


\section{PIT Tag Longevity}

Introduction

Although the tag manufacturer conducted simulated life expectancy tests for the PIT tag and estimated functional life at over 10 years, overall life expectancy and reliability under operating conditions are unknown. The objective of the current study was to determine under field conditions the longevity of glass-encapsulated PIT tags placed in juvenile salmon.

Methods and Materials

In early spring 1986, two 300-fish groups of juvenile fall chinook salmon were established at the Big Beef Creek Research Station-- the control group was established on 14 April and the glass-encapsulated PIT tag group on 15 April (Table 3). All fish in each group were weighed $( \pm 0.5 \mathrm{~g})$ and measured $( \pm 3.0 \mathrm{~mm})$. Tags were injected into the fish's body cavity using the method described in Appendix A. The PIT tag identification number of each tagged fish was recorded. The two test groups were maintained in separate tanks during freshwater culture.

At the time of smoltification (as determined by visual observations), all fish were transported to the NMFS Manchester Marine Experimental station near Manchester, Washington; vaccinated against vibrio sp.; and acclimated to seawater over a 5-d period. At seawater transfer (6 May 1986), 294 PIT-tagged and 298 control fish were counted and measured $( \pm 3.0 \mathrm{~mm})$ and the identification codes (and presence) were verified for the tagged group.

The PIT tag and control groups are being maintained in separate seawater net-pens. Standard husbandry practices are being followed for the duration of the study. Dead fish are necropsied, and the presence of the tag verified if applicable. Additional observations as to tag presence and (functional) 
operation took place on $22 \mathrm{July}$, and 19 September 1986 and 7 January and 21 May 1987. Fish were measured $(\sim 3.0 \mathrm{~mm})$ at each observation period. No weight data were obtained because of the difficulty of accurately weighing fish due to wave action at the seawater site. This study is ongoing, and the fish are being maintained as discrete test groups until maturity.

Growth comparisons were analyzed by standard ANOVA techniques, and survival data were compared using $\mathbf{G}^{2}$ statistics (Sokal and Rohlf 1981).

Results and Discussion

A total of 21 days for the PIT-tagged and 22 days for the control group elapsed between the time this experiment was established and the fish were transferred to seawater. During the freshwater phase, only one control fish died and there were no documented mortalities among PIT-tagged fish. However, there were six missing fish in the PIT tag group and one in the control group. For purposes of analysis, these fish were included in the data as mortalities (Table 3). There was no difference $(P<0.05)$ in survival between the PIT-tagged and control fish during the freshwater portion of this study. In addition, during the freshwater portion of this experiment, all PIT tags were fully functional and no tag rejection was noted (Table 4).

During seawater culture, to the last observation date on 21 May 1987, 34 fish from the PIT-tagged group (11.6\%) and 31 from the control group (10.4\%) had died or were missing from the population (Table 3). During the seawater portion of this study, there was no difference $(\mathrm{P}<0.05)$ in survival between the PITtagged and control fish. The probable cause of death in the mortalities from both groups was diagnosed as bacterial kidney disease. During the seawater culture phase, all PIT tags from live and dead fish were fully functional and no tag rejection was noted (Tables 3 and 4). 
Tabl e 3. -- 1986 I ongevl ty study--i nventory records. grouth data. and tag i nf ormati on.

\begin{tabular}{|c|c|c|c|c|c|c|c|c|c|c|c|}
\hline \multirow{3}{*}{$\begin{array}{l}\text { Sanpl e } \\
\text { peri od b }\end{array}$} & \multirow[b]{3}{*}{ Treat nent } & \multirow[b]{3}{*}{ Day } & \multirow[b]{3}{*}{ Nb. } & \multicolumn{2}{|c|}{ Stock inventory } & \multicolumn{2}{|c|}{ PI T tags } & \multicolumn{4}{|c|}{ Size ${ }^{a}$} \\
\hline & & & & \multicolumn{2}{|c|}{ Mrtalities } & \multirow[b]{2}{*}{ Rej ect ed } & \multirow{2}{*}{$\begin{array}{c}\text { Non- } \\
\text { f uncti onal }\end{array}$} & \multicolumn{2}{|c|}{$\begin{array}{l}\text { Length } \\
(\mathrm{m})\end{array}$} & \multicolumn{2}{|c|}{$\begin{array}{l}\text { Wei ght } \\
\text { (g) }\end{array}$} \\
\hline & & & & Docunent ed & M ssi ng & & & Mean & SD & Mean & SD \\
\hline \multirow[t]{2}{*}{$1-F . H}$. & PI T-t agged & 0 & 300 & $\cdots$ & $\cdots$ & 0 & 0 & $69 *$ & 4 & $3.4^{*}$ & 0.6 \\
\hline & Control & 0 & 300 & $\cdots$ & $\cdots$ & $\cdots$ & $\cdots$ & $68 *$ & 3 & $3.6^{*}$ & 0.6 \\
\hline 2-F.W & PI T-tagged & 21 & 294 & 0 & 6 & 0 & 0 & $75^{*}$ & 3 & 5.2 & 0.7 \\
\hline (transf er) & Control & 22 & 298 & 0 & 2 & $\cdots$ & $\cdots$ & $77 *$ & 4 & 5.4 & 0.8 \\
\hline \multirow[t]{2}{*}{ 1-S. W } & PI T-t tagged & 98 & 270 & 16 & 0 & 0 & 0 & $112 *$ & 10 & $\cdots$ & $\cdots$ \\
\hline & Control & 99 & 289 & 9 & 0 & --- & --- & $117 *$ & 9 & $\cdots$ & $\cdots$ \\
\hline \multirow[t]{2}{*}{ 2-S.W } & PI T-t tagged & 157 & 268 & 10 & 0 & 0 & 0 & $151^{*}$ & 15 & $\cdots$ & $\cdots$ \\
\hline & Control & 158 & 277 & 10 & 2 & $\cdots$ & $\cdots$ & 155* & 14 & $\cdots$ & $\cdots$ \\
\hline \multirow[t]{2}{*}{ 3-S. W } & PI T-t agged & 267 & 262 & 4 & 2 & 0 & 0 & $220^{*}$ & 23 & $\cdots$ & $\cdots$ \\
\hline & Control & 268 & 271 & 8 & 0 & $\cdots$ & $\cdots$ & $226^{\prime \prime}$ & 19 & $\cdots$ & $\cdots$ \\
\hline \multirow[t]{2}{*}{ 4-S. W } & PI T-t tagged & 401 & 260 & I & 1 & 0 & 0 & 298 & 28 & & $\cdots$ \\
\hline & Control & 402 & 269 & 2 & 0 & $\cdots$ & $\cdots$ & 307 & 25 & & $\cdots$ \\
\hline
\end{tabular}

a $\quad$ DD = standard devi ati on, wei ghts not recorded during seavater residence.

* = Significantly ( $P<Q \infty$ O) different for sampling period compari son (tagged vs control).

b $F$. .W. = fresh water, S.W. = seavater. 
Table 4.--Survival and tag retention information for 1986 Big Beef Creek fall chinook salmon longevity study.

\begin{tabular}{|c|c|c|c|c|c|c|c|c|}
\hline \multirow[b]{2}{*}{$\begin{array}{l}\text { Treatment } \\
\text { (No- ) }\end{array}$} & \multirow{2}{*}{$\begin{array}{l}\text { Size at } \\
\text { tagging } \\
\text { (g) }\end{array}$} & \multirow{2}{*}{$\begin{array}{l}\text { Test } \\
\text { period } \\
\text { (days) }\end{array}$} & \multicolumn{3}{|c|}{ Survival a } & \multicolumn{3}{|c|}{$\begin{array}{c}\text { Tag retention } \\
\text { and operational } \\
\text { rellabllity }\end{array}$} \\
\hline & & & $\mathrm{FW}$ & $\begin{array}{l}\text { SW } \\
\left(\frac{0}{0}\right)\end{array}$ & Total & $\mathrm{FW}$ & $\begin{array}{l}\text { SW } \\
\left(\frac{\circ}{0}\right)\end{array}$ & Total \\
\hline \multirow[t]{2}{*}{$\begin{array}{l}\text { Control } \\
(n=300)\end{array}$} & 3.6 & $\begin{array}{rl}22 & \mathrm{FW} \\
380 & \mathrm{SW}\end{array}$ & 99.3 & 90.3 & 89.7 & - & - & - \\
\hline & & 402 Total & & & & & & \\
\hline \multirow[t]{2}{*}{$\begin{array}{l}\text { PIT-tagged } \\
(\mathrm{n}=300)\end{array}$} & 3.4 & $\begin{array}{rr}21 & F W \\
380 & \text { SW }\end{array}$ & 98.0 & 88.4 & 86.7 & 100 & 100 & 100 \\
\hline & & 401 Total & & & & & & \\
\hline
\end{tabular}

$\mathbf{a}_{\mathrm{FW}}=$ freshwater culture period; $\mathrm{SW}=$ seawater culture period. 
Additionally, growth comparisons in fresh water and seawater, indicate there were slight, but statistically significant $(\mathrm{P}<0.05)$, differences in length and or weight between the tagged and control groups at most sampling periods (Table 3 and Fig 1). These size differences are minor (3\% or less), and we do not believe they are of biological importance.

Overall tag retention and longevity were excellent, 100\% of the PIT tags functioned properly and no tag rejection was noted. Overall survival was $86.7 \%$ for the PIT-tagged and 89.7\% for the control groups and did not differ statLstically $\quad(P<0.05) \quad($ Table 4$)$.

In an earlier study using a polypropylene encapsulated version of the PIT tag, Prentice et al. (1985) noted unacceptable (13.3\%) tag failure and high (14.6\%) tag rejection during a 341-day study. This poor performance was attributed to leaks in and rough edges on the polypropylene case of this early version of the PIT tag. The present study using the glass-encapsulated verison of the PIT tag is ongoing. The fish will be held in seawater at Manchester to maturity, thus, this study should ultimately provide an understanding of tag function through a complete life cycle for chinook salmon. Results to date indicate that glass-encapsulation provides a tag that is smooth, leak proof, and seemingly biologically inert. The glass-encapsulated version of the PIT tag appears to be a reliable tag that should have a long life span and low rejection rate.

\footnotetext{
Effect of PIT tag on Swimming Ability of Hatchery and Migrating Salmonids
}

Introduct ion

Changes in swimming stamina levels are reliable indicators of stress in fish; depressions in swimming stamina levels have been noted in teleost fish 


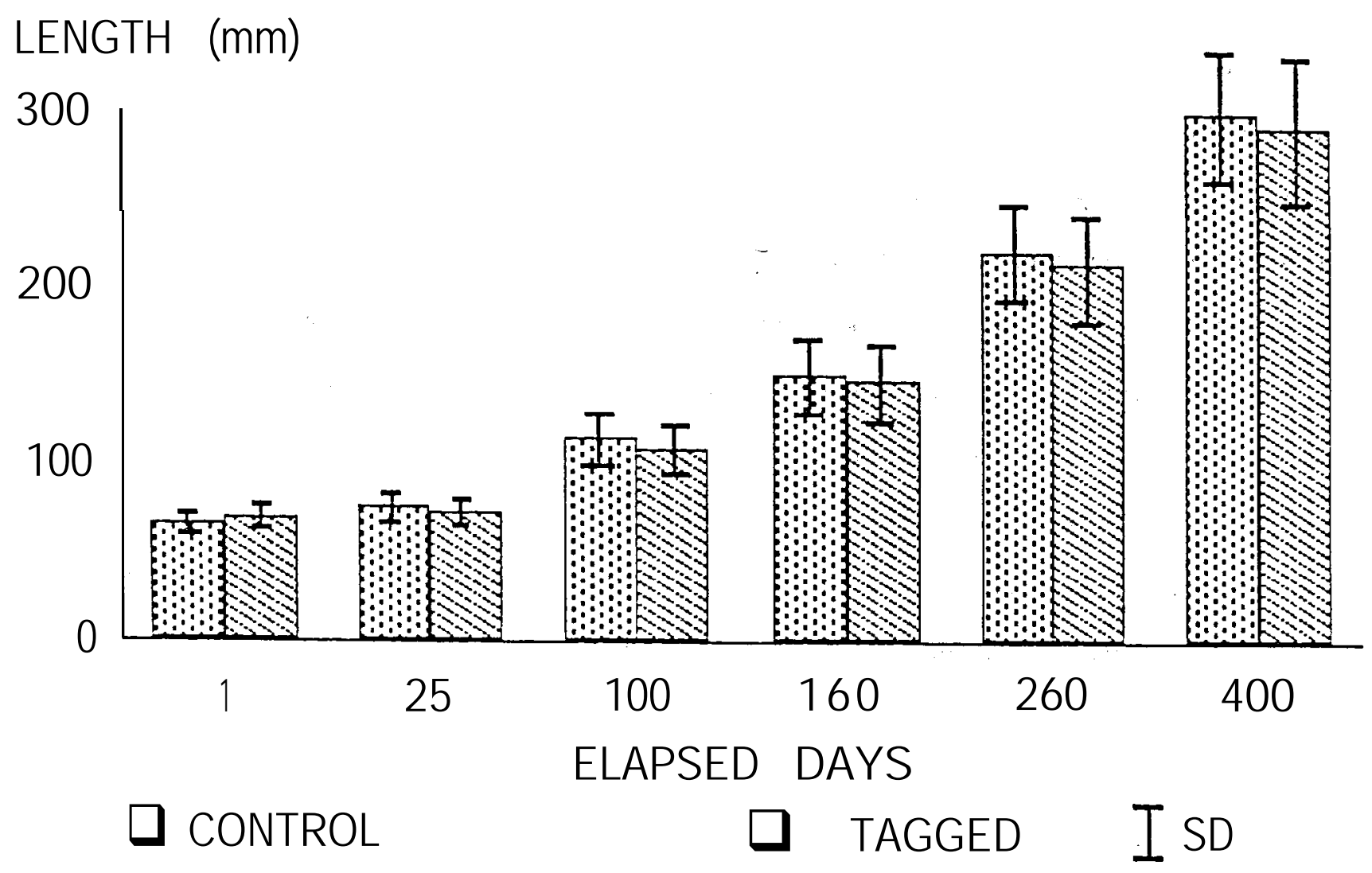

Figure 1.--Comparison of growth (length) of PIT-tagged and control fall chinook salmon. 
upon exposure to many stress inducing agents (McCleave and Stred 1975; Beamish 1978; Flagg 1981; Lewis and Muntz 1984). Likewise, alterations in tail beat profile and opercular beat rate have been linked to changes in physiological condition of fish (Beamish 1978; Stevens 1979; Flagg and Smith 1982; Lewis and Muntz 1984). In addition, post-swimming fatigue survival has been shown to be positively linked to the fish's physiological condition (Flagg et al. 1983).

The presence of large foreign objects (e.g., radio telemetry type tags) in and on fish have the potential to compromise swimming ability (McCleave and Stred 1975; Lewis and Muntz 1984). However, the glass-encapsulated version of the PIT tag measures about 2 by $12 \mathrm{~mm}$, weighs less than $0.05 \mathrm{~g}$, and is only about 3\% of the volume of more common type radio transmitter tags. Earlier investigations with the polypropylene version of the PIT tag showed that the tag did not compromise the swimming ability of juvenile steelhead (Prentice et al. 1986). The present study documents the effect of the glass encapsulated version of the PIT tag on in-hatchery (juvenile) chinook salmon and steelhead. In addition, tests conducted at McNary Dam on migrating yearling and underyearling chinook salmon and steelhead compared PIT tagging to other traditional marking methods (i.e., freeze branding and coded wire tagging) and assessed the effect of each of these methods on the fish's swimming ability.

Methods and Materials

Swimming ability tests were conducted in a modified version of the Blaska respirometer-stamina chamber described by Smith and Newcomb (1970) (Fig. 2) . These chambers were divided into multiple compartments to allow the simultaneous testing of four fish. Each chamber was equipped with an electrified screen at the downstream end, assuring maximum fish performance. In these tests, fish were individually anesthetized Ctricaine methanesulfonate (MS-222)], weighed 

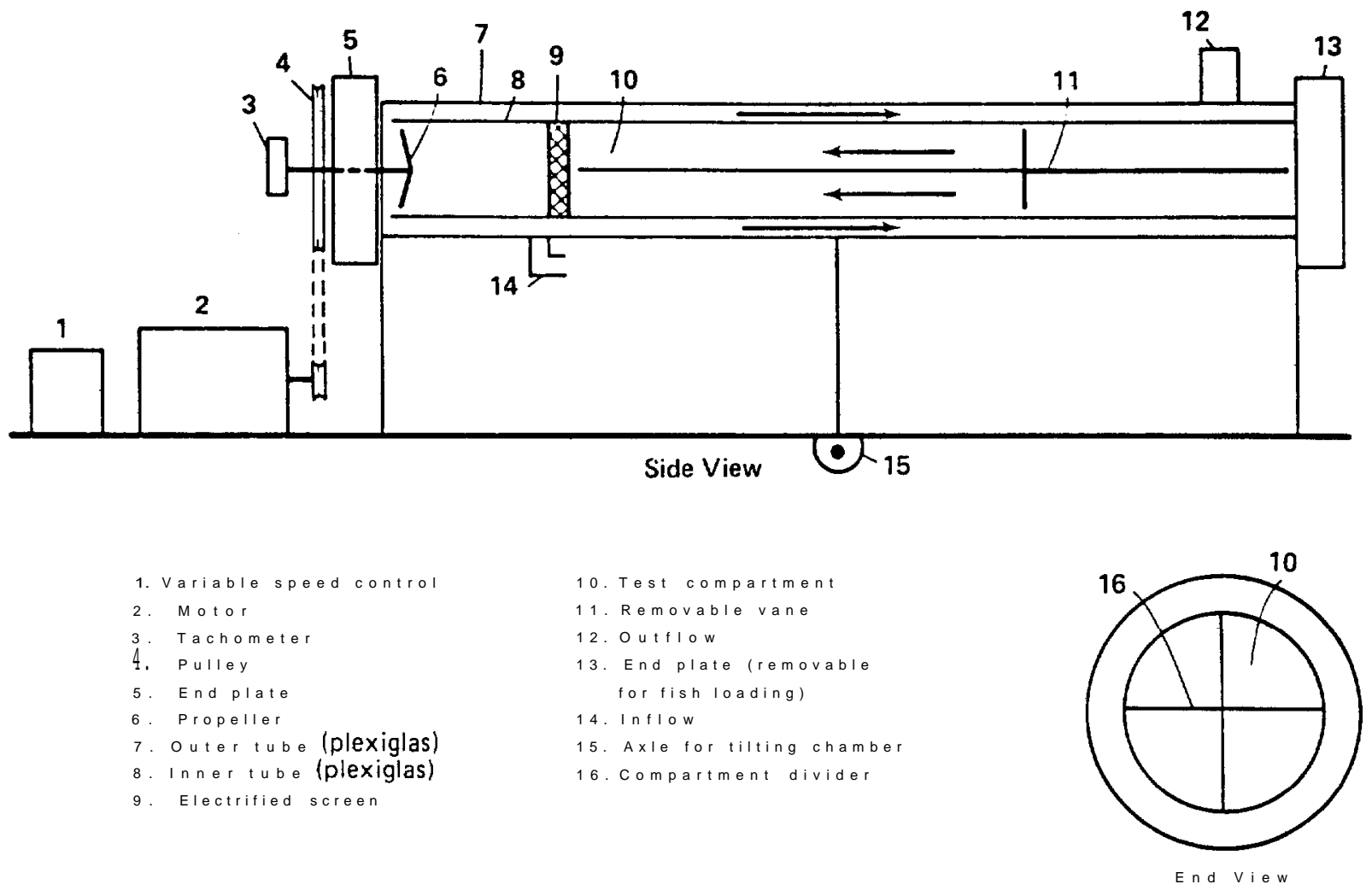

Figure 2 .--Diagram of modified Blaska respirometer-stamina chamber. 
$( \pm 0.1 \mathrm{~g})$, measured as to fork length $( \pm 1 \mathrm{~mm})$, and then placed into a test compartment. After a l-h recovery, the initial water velocity was set at 1.5 body lengths (mean) per second $(1 / \mathrm{s})$ and increased $0.5 \mathrm{l} / \mathrm{s}$ every 15 minutes until all fish reached fatigue (i.e., could no longer hold position in the current and remained impinged against the electrified screen).

A swimming stamina value (U-critical) was established for each group using the swimming speed at fatigue and the time to fatigue as an integrated time/velocity measure of impingement by the methods described in Beamish (1978). Individual swimming speed was corrected for the effects of solid blocking (for any fish whose cross-sectional area was greater than $10 \%$ of the cross-sectional area of its swimming compartment) using methods described by Bell and Terhune (1970) .

Tail-beat frequency (TBF), recorded as beats per minute, and opercular beat rate (OBR) per minute were monitored using a video camera with a superimposed stop watch. Data were recorded with fish maintaining position in the central portion of the swimming tunnel and not moving relative to the video recording equipment. The TBF and OBR were normally documented two or three times throughout each 15-minute increment. The TBF data allowed stride efficiency number of tail beats per minute required to maintain a unit swimming speed of one body length per second) to be compared.

In-hatchery tests were conducted at the Big Beef Creek Research Station using fish reared on station. One size of steelhead (61.6 g average) were evaluated beginning 17 March 1986 whereas tests on 3.7 and $8.6 \mathrm{~g}$ average fall chinook salmon were begun on 14 April and 02 June 1986, respectively (Table 5). At testing, random samples $(\mathrm{n}=200)$ were removed from the main population and interperitoneally tagged with the PIT tag using procedures described in Appendix A. A control (non-tagged) group ( $n=200$ ) was also established from the 
Table 5.--Size of fish used in swimming ability studies.

\begin{tabular}{|c|c|c|c|c|}
\hline \multirow[b]{2}{*}{ Test site/species a } & \multicolumn{2}{|c|}{ Length } & \multicolumn{2}{|c|}{ Weight } \\
\hline & $\mathrm{mm}$ & SD & 8 & $\mathrm{SD}$ \\
\hline In-hatchery tests & & & & \\
\hline Steelhead & 171 & 18 & 61.6 & 17.2 \\
\hline Fall chinook salmon & 67 & 4 & 3.7 & 0.9 \\
\hline Fall chinook salmon & 89 & 7 & 8.6 & 2.2 \\
\hline
\end{tabular}

\section{In-river tests}

\begin{tabular}{|c|c|c|c|c|c|c|}
\hline Yearling chinook salmon & 137 & 11 & 23.9 & \multicolumn{2}{|c|}{5.7} & \\
\hline Steelhead & 2,01 & 24 & 68.7 & 2 & 0 & \\
\hline $\begin{array}{l}\text { Underyearling } \\
\text { chinook salmon }\end{array}$ & 111 & 10 & 14.5 & & & \\
\hline
\end{tabular}

a In-hatchery tests designate fish reared and tested at the Big Beef Creek facility near Seabeck, WA; in-river tests designate migrating fish collected and tested at the McNary Dam juvenile fish collection facility near Umatilla, OR. 
main population at this time. Swimming performance tests were conducted for 12 PIT- tagged and 4 control fish randomly selected on Day 0 (same as tagging) and on Days 1, 2, 3, 4, 7, 9, 11, 14, and 17 for all groups (Fig. 3). The steelhead were also tested on Days 21 and 25 whereas the small and large fall chinook salmon were tested on Days 21 and 23, respectively. In addition, only swimming stamina was assessed on Days 9-25 for the steelhead. For each group of fish tested both daily and overall (pooled) data comparisons were evaluated between test and control fish.

All in-hatchery fish tested (tagged and control) were held for $14 \mathrm{~d}$ post-test to establish survival profiles. These fish were fed daily and populations inspected regularly to document mortality. At the end of the 14-d holding period, all fish were examined to determine tag retention.

Testing of in-river migrating fish was conducted at McNary Dam using migrants collected at the juvenile collection facility. In this study, swimming ability was compared between PIT-tagged, coded-wire-tagged (CWT), freezebranded, and control fish (handled but not tagged or branded). Fish were received from the marking line at the juvenile facility at McNary Dam and marked or tagged as appropriate. Ten fish from each group were placed into 114-liter portable holding containers supplied with ambient river water. These fish were held for $24 \mathrm{~h}$, and then swimming performance tests were conducted on six randomly selected fish from each of the four groups. This procedure was repeated daily for $5 \mathrm{~d}$ and the data pooled to provide a total sample size of 30 fish from each group for comparison (Fig. 3).

Migrating yearling chinook salmon (23.9 g average) were evaluated between 13 and 17 May 1986 whereas underyearling chinook salmon (14.5 g average) were tested from 8 to 12 July 1986. The spring outmigration for yearling chinook salmon is primarily composed of spring, summer, and fall races. The sub-yearling 
Hatchery tests

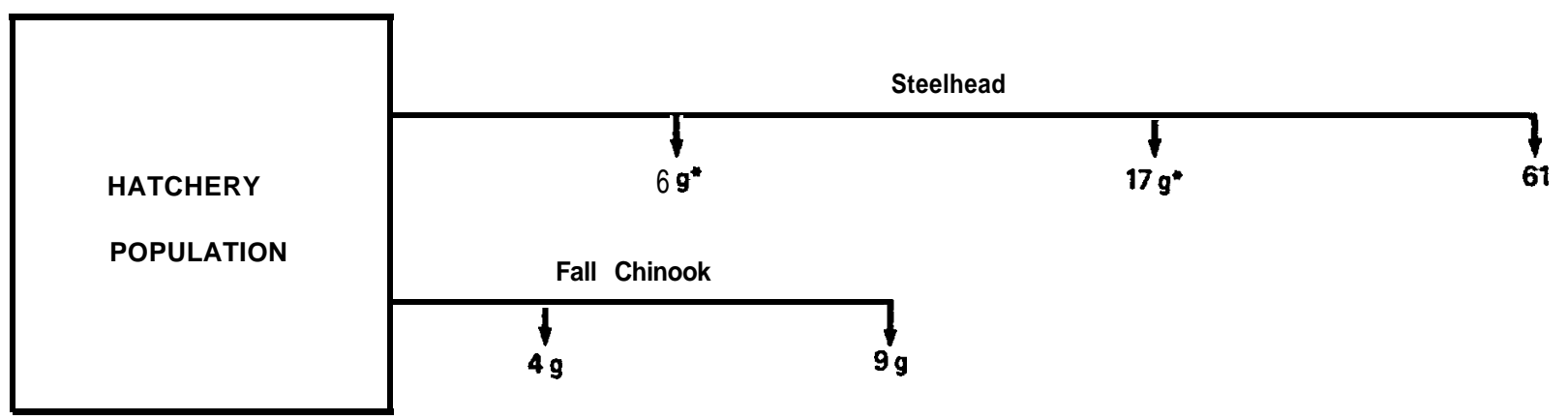

McNary Dam Outmigrant Tests

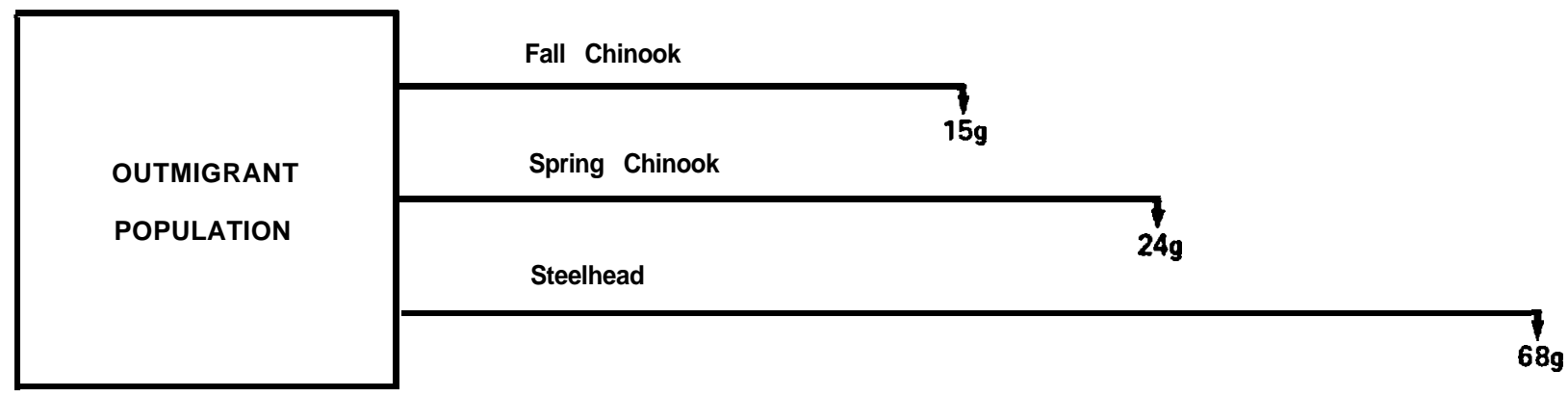

Figure 3.--Testing plan for swimming ability tests conducted in 1985 and 1986. 
outmigration is primarily composed of fall chinook salmon. Steelhead $168.7 \mathrm{~g}$ average) were tested from 18 to 22 May 1986 (Table 5). All tested fish were held for $5 \mathrm{~d}$ post-test to establish stress survival profiles. These populations were inspected regularly to document mortality. At the end of the S-d holding period, all PIT-tagged fish were examined to determine tag retention.

Additional comparisons of in-river fish were made using fin clips in the manner commonly used by researchers conducting migration studies. One-half $(n=15)$ of the freeze-branded group in the steelhead test was upper caudal clipped, and swimming stamina was compared between these subgroups. For both the in-hatchery and in-river tests, swimming stamina data, stride efficiency data, and respiratory rate data were compared between tagged and control fish using the non-parametric Mann-Whitney test. Survival data were analyzed using the $\mathrm{G}^{2}$ procedure. All data analysis followed the methods of Sokal and Rohlf (1981).

Results and Discussion

In an earlier study using the polypropylene version of the PIT tag, we presented evidence that the PIT tag did not compromise the swimming stamina, stride efficiency, opercular beat rate, or post fatigue survival of two size ranges of (in-hatchery) steelhead (Prentice et al. 1986). In the present study, in-hatchery tests were conducted for one size group of (61.6 g average) steelhead and two size ranges (averages $=3.7$ and $8.6 \mathrm{~g}$ ) of fall chinook salmon using the glass-encapsulated version of the PIT tag. Daily comparisons indicated there were no statistical differences $(P<0.05)$ in swimming stamina or stride efficiency between tagged and control fish at any test day (post-tag) for any group (Tables 6, 7, and 8). Analysis of the respiratory rate data (OBR) showed statistical differences $(P<0.05)$ between tagged and control fish on 2 of 
Table 6.--Stride efficiency, opercular beat rate, and swimming
stamina of PIT-tagged and control steelhead (61.6-g

able 6.--Stride efficiency, opercular beat rate, and swimming
stamina of PIT-tagged and control steelhead (61.6-g average).'

\begin{tabular}{|c|c|c|c|c|c|c|c|}
\hline \multicolumn{2}{|c|}{$\begin{array}{l}\text { Test } \\
\text { day } \\
\text { post }\end{array}$} & \multicolumn{2}{|c|}{$\begin{array}{l}\text { Stride } \\
\text { efficiency a }\end{array}$} & \multicolumn{2}{|c|}{$\begin{array}{l}\text { Opercular } \\
\text { beat rate } \mathbf{a}\end{array}$} & \multicolumn{2}{|c|}{$\begin{array}{l}\text { Swimming } \\
\text { stamina }\end{array}$} \\
\hline tag & Group b & Mean & $\mathrm{SD}$ & Mean & $\mathrm{SD}$ & Mean & $\mathrm{SD}$ \\
\hline \multirow[t]{2}{*}{0} & $\mathrm{~T}$ & 121.9 & 18.7 & 143.5 & 14.6 & 3.1 & 0.2 \\
\hline & $\mathrm{C}$ & 122.2 & 16.7 & 129.5 & 22.5 & 3.2 & 0.3 \\
\hline \multirow[t]{2}{*}{1} & $\mathrm{~T}$ & 127.2 & 18.8 & 139.1 & 16.9 & 3.0 & 0.5 \\
\hline & $\mathrm{C}$ & 119.6 & 19.2 & 136.2 & 10.0 & 3.2 & 0.3 \\
\hline \multirow[t]{2}{*}{2} & $\mathrm{~T}$ & 119.4 & 16.0 & $130.8 *$ & 15.0 & 3.2 & 0.2 \\
\hline & $\mathrm{C}$ & 125.9 & 19.6 & $146.3 *$ & 13.0 & 3.3 & 0.2 \\
\hline \multirow[t]{2}{*}{3} & $\mathrm{~T}$ & 132.3 & 19.0 & 136.0 & 13.8 & 3.0 & 0.4 \\
\hline & $\mathrm{C}$ & 123.5 & 20.1 & 138.7 & 11.3 & 3.1 & 0.1 \\
\hline \multirow[t]{2}{*}{4} & $\mathrm{~T}$ & 129.8 & 22.6 & 139.2 & 11.6 & 3.2 & 0.2 \\
\hline & $\mathrm{C}$ & 122.7 & 18.8 & 124.2 & 44.1 & 3.0 & 0.4 \\
\hline \multirow[t]{2}{*}{7} & $\mathrm{~T}$ & 125.7 & 18.9 & 129.9 & 27.1 & 3.1 & 0.1 \\
\hline & $\mathrm{C}$ & 116.5 & 19.7 & 141.8 & 18.2 & 3.0 & 0.2 \\
\hline \multirow[t]{2}{*}{9} & $\mathrm{~T}$ & -- & -- & -- & -- & 3.2 & 0.3 \\
\hline & $\mathrm{C}$ & -- & -- & -- & -- & 3.2 & 0.4 \\
\hline \multirow[t]{2}{*}{11} & $\mathrm{~T}$ & -- & -- & -- & -- & 3.2 & 0.2 \\
\hline & C & -- & -- & -- & -- & 3.2 & 0.2 \\
\hline \multirow[t]{2}{*}{14} & $\mathrm{~T}$ & -- & -- & -- & -- & 3.3 & 0.3 \\
\hline & $\mathrm{C}$ & -- & -- & -- & -- & 3.0 & 0.4 \\
\hline \multirow[t]{2}{*}{17} & $\mathrm{~T}$ & -- & -- & -- & -- & 3.1 & 0.5 \\
\hline & $\mathrm{C}$ & -- & -- & -- & -- & 2.8 & 0.6 \\
\hline \multirow[t]{2}{*}{21} & $\mathrm{~T}$ & -- & -- & -- & -- & 3.1 & 0.2 \\
\hline & $\mathrm{C}$ & -- & -- & -- & -- & 2.9 & 0.3 \\
\hline \multirow[t]{2}{*}{25} & $\mathrm{~T}$ & -- & -- & -- & -- & 3.0 & 0.3 \\
\hline & C & -- & -- & -- & -- & 3.1 & 0.3 \\
\hline \multirow[t]{3}{*}{ Poole } & ed data & & & & & & \\
\hline & $\mathrm{T}$ & 125.6 & 18.9 & 136.5 & 17.3 & 3.1 & 0.3 \\
\hline & $\mathrm{C}$ & 122.5 & 18.4 & 135.5 & 21.3 & 3.1 & 0.3 \\
\hline
\end{tabular}

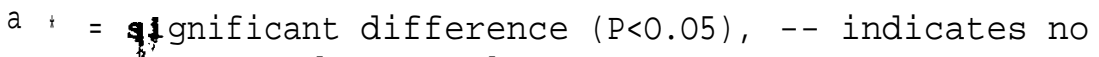
meas ements documented.

b $\mathbf{T}=1 \mathrm{~T}$ tagged ( $\mathrm{n}=12$ tagged fish tested each day), $\mathrm{c}=$ ontrol ( $\mathrm{n}=4$ control fish tested each day).
} 
Table $7 .--$ Stride efficiency, opercular beat rate, and swimming stamina of PIT-tagged and control fall chinook salmon (3.7-g average).

\begin{tabular}{|c|c|c|c|c|c|c|c|}
\hline \multirow{2}{*}{\multicolumn{2}{|c|}{$\begin{array}{l}\text { Test } \\
\text { day } \\
\text { post } \\
\text { tag Group' b }\end{array}$}} & \multicolumn{2}{|c|}{$\begin{array}{c}\text { Stride } \\
\text { efficiency }\end{array}$} & \multicolumn{2}{|c|}{$\begin{array}{l}\text { Opercular } \\
\text { beat rate }\end{array}$} & \multicolumn{2}{|c|}{$\begin{array}{l}\text { Swimming } \\
\text { stamina }\end{array}$} \\
\hline & & Mean & SD & Mean & SD & Mean & $\mathrm{SD}$ \\
\hline \multirow[t]{2}{*}{0} & $\mathrm{~T}$ & 122.5 & 33.8 & 130.3 & 16.0 & 5.6 & 0.3 \\
\hline & C & 120.3 & 37.8 & 131.5 & 20.0 & 5.7 & 0.4 \\
\hline \multirow[t]{2}{*}{1} & $\mathrm{~T}$ & 128.2 & 36.0 & 132.7 & 17.7 & 5.2 & 0.4 \\
\hline & C & 128.2 & 33.0 & 132.5 & 15.3 & 5.2 & 0.4 \\
\hline \multirow[t]{2}{*}{2} & $\mathrm{~T}$ & 119.6 & 34.3 & 134.8 & 16.7 & 5.6 & 0.3 \\
\hline & C & 121.2 & 34.1 & 137.3 & 17.3 & 5.5 & 0.2 \\
\hline \multirow[t]{2}{*}{3} & $\mathrm{~T}$ & 120.8 & 37.4 & 132.0 & 24.1 & 5.8 & 0.4 \\
\hline & C & 119.6 & 35.0 & 129.5 & 20.5 & 5.8 & 0.2 \\
\hline \multirow[t]{2}{*}{4} & $\mathrm{~T}$ & 119.6 & 37.3 & 138.7 & 20.2 & 5.8 & 0.5 \\
\hline & C & 123.2 & 37.3 & 133.6 & 24.5 & 5.8 & 0.2 \\
\hline \multirow[t]{2}{*}{7} & $\mathrm{~T}$ & 124.3 & 40.7 & 136.9 & 20.0 & 5.4 & 0.5 \\
\hline & C & 119.3 & 35.3 & 133.7 & 28.7 & 5.9 & 0.5 \\
\hline \multirow[t]{2}{*}{9} & $\mathrm{~T}$ & 126.5 & 38.6 & $134.2 *$ & 17.8 & 5.4 & 0.4 \\
\hline & C & 122.7 & 42.0 & $147.2 *$ & 18.6 & 5.6 & 0.4 \\
\hline \multirow[t]{2}{*}{11} & $\mathrm{~T}$ & 129.7 & 38.3 & 148.2 & 41.1 & 5.5 & 0.3 \\
\hline & C & 132.8 & 51.6 & 156.2 & 59.7 & 5.5 & 0.3 \\
\hline \multirow[t]{2}{*}{14} & $\mathrm{~T}$ & 126.6 & 37.6 & 140.1 & 19.6 & 5.3 & 0.3 \\
\hline & C & 124.2 & 40.9 & 137.1 & 23.6 & 5.5 & 0.1 \\
\hline \multirow[t]{2}{*}{17} & $\mathrm{~T}$ & 125.3 & 37.0 & $142.3 *$ & 18.9 & 5.2 & 0.3 \\
\hline & C & 119.0 & 35.4 & $131.0 *$ & 17.3 & 5.4 & 0.3 \\
\hline \multirow[t]{2}{*}{21} & $\mathrm{~T}$ & 126.1 & 37.1 & 137.2 & 18.0 & 5.3 & 0.5 \\
\hline & C & 114.5 & 33.3 & 139.2 & 24.2 & 5.7 & 0.1 \\
\hline \multicolumn{8}{|c|}{ Pooled data } \\
\hline & $\mathrm{T}$ & 125.1 & 37.3 & 136.8 & 22.6 & 5.4 & 0.4 \\
\hline & C & 122.9 & 37.9 & 137.2 & 27.5 & 5.5 & 0.4 \\
\hline
\end{tabular}

$a^{*}=$ significant difference $(\mathrm{P}<0.05)$.

b $\mathrm{T}=$ PIT tagged, $\mathrm{n}=12$ tagged fish tested each day $\mathrm{C}=$ control, $\mathrm{n}=4$ control fish tested each day. 
Table 8.--Stride efficiency, opercular beat rate, and swimming stamina of PIT tagged and control fall chinook salmon (8.6-g average).

\begin{tabular}{|c|c|c|c|c|c|c|c|}
\hline \multirow{2}{*}{$\begin{array}{l}\text { Test } \\
\text { day } \\
\text { post } \\
\text { tag }\end{array}$} & \multirow{2}{*}{ Group b } & \multicolumn{2}{|c|}{$\begin{array}{c}\text { Stride } \\
\text { efficlency }\end{array}$} & \multicolumn{2}{|c|}{$\begin{array}{l}\text { Opercular } \\
\text { beat rate a }\end{array}$} & \multicolumn{2}{|c|}{$\begin{array}{l}\text { Swimming } \\
\text { st a m i n a }\end{array}$} \\
\hline & & Mean & SD & Mean & SD & Mean & $\mathrm{SD}$ \\
\hline \multirow[t]{2}{*}{0} & $\mathrm{~T}$ & 122.6 & 28.1 & $131.4 *$ & 15.4 & 4.7 & 0.7 \\
\hline & C & 127.1 & 32.1 & $140.9 *$ & 11.7 & 5.0 & 0.5 \\
\hline \multirow[t]{2}{*}{1} & $\mathrm{~T}$ & 124.1 & 35.0 & 137.6 & 15.4 & 4.6 & 0.7 \\
\hline & C & 120.7 & 30.2 & 129.5 & 14.3 & 4.9 & 0.5 \\
\hline \multirow[t]{2}{*}{2} & $\mathrm{~T}$ & 122.7 & 28.7 & 127.2 & 19.0 & 5.0 & 0.4 \\
\hline & C & 121.7 & 27.1 & 121.0 & 21.6 & 5.1 & 0.1 \\
\hline \multirow[t]{2}{*}{3} & $\mathrm{~T}$ & 124.1 & 28.5 & 123.1 & 15.9 & 4.9 & 0.3 \\
\hline & C & 119.8 & 25.5 & 130.7 & 18.8 & 4.8 & 0.4 \\
\hline \multirow[t]{2}{*}{4} & $\mathrm{~T}$ & 122.1 & 27.6 & 128.9 & 18.4 & 4.9 & 0.5 \\
\hline & C & 123.8 & 30.0 & 129.4 & 13.1 & 4.8 & 0.5 \\
\hline \multirow[t]{2}{*}{7} & $\mathrm{~T}$ & 122.6 & 26.9 & 131.9 & 17.8 & 4.5 & 0.6 \\
\hline & C & 120.8 & 30.1 & 130.0 & 18.5 & 4.1 & 1.0 \\
\hline \multirow[t]{2}{*}{17} & $\mathrm{~T}$ & 128.9 & 25.2 & 124.9 & 19.2 & 4.3 & 0.4 \\
\hline & C & 132.2 & 29.0 & 133.1 & 17.2 & 4.3 & 0.4 \\
\hline \multirow[t]{2}{*}{23} & $\mathrm{~T}$ & 130.3 & 26.6 & 127.2 & 14.3 & 4.1 & 0.3 \\
\hline & C & 132.2 & 32.6 & 131.5 & 11.3 & 4.3 & 0.3 \\
\hline \multicolumn{8}{|c|}{ Pooled data } \\
\hline & $\mathrm{T}$ & 124.4 & 28.9 & 130.7 & 17.2 & 4.6 & 0.6 \\
\hline & C & 124.4 & 29.7 & 130.8 & 15.3 & 4.7 & 0.6 \\
\hline
\end{tabular}

a $*$ = significant difference $(P<0.05)$.

b $\mathrm{T}=\mathrm{PIT}$ tagged ( $\mathrm{n}=12$ tagged fish tested each day) $\mathrm{C}=$ control $(\mathrm{n}=4$ control fish tested each day). 
$11 \mathrm{~d}$ for the 3.7-g average fall chinook salmon, 1 of 8 for $8.7-g$ average fall chinook salmon, and 1 of $6 \mathrm{~d}$ for steelhead (Tables 6, 7, and 8). However, there was no obvious trend to these differences, and we do not believe they have any biological importance. Pooled comparisons indicated there was no overall statistical difference $(P<0.05)$ in swimming stamina, stride efficiency, or respiratory rate between tagged and control fish for any test group (Tables 6, 7, and 8 and Figs. 4, 5, and 6).

Neither the act of tagging nor the presence of the PIT tag had any effect on (in-hatchery) post-test survival; none of the PIT-tagged nor control fish died after testing in any of the Big Beef Creek Hatchery tests (100\% survival). In addition, in all cases, PIT tag retention was $100 \%$ during the 14 -d post-test holding period, indicating that severe (swimming) exercise has no adverse influence on PIT tag retention.

This study confirms the earlier work of Prentice et al. (1986) and indicates that the glass-encapsulated version of the PIT tag will not effect the swimming ability of salmonids in a hatchery situation.

Tests conducted at McNary Dam helped define the effects of the PIT tag on in-river migrating salmonids. These tests suggest that the PIT tag will not compromise the ability of migrating steelhead or underyearling and yearling chinook salmon. The Mann-Whitney tests indicated no statistical difference $(\mathrm{P}<0.05)$ in stamina, stride efficiency, or respiratory rate for $\mathrm{PIT}$-tagged compared to control fish for any species tested (Table 9, and Figs. 7, 8, and 9).

Swimming stamina and respiratory rate of coded-wire-tagged fish and freezebranded fish were similar $(\mathrm{P}<0.05)$ to controls for all species tested. In addition, stride efficiency of freeze-branded fish was similar $(P<0.05)$ to controls in all cases. However, stride efficiency of the coded-wire-tagged 


\section{SWIMMING STAMINA}

\section{(BODY L.ENGTHS/SEC)}

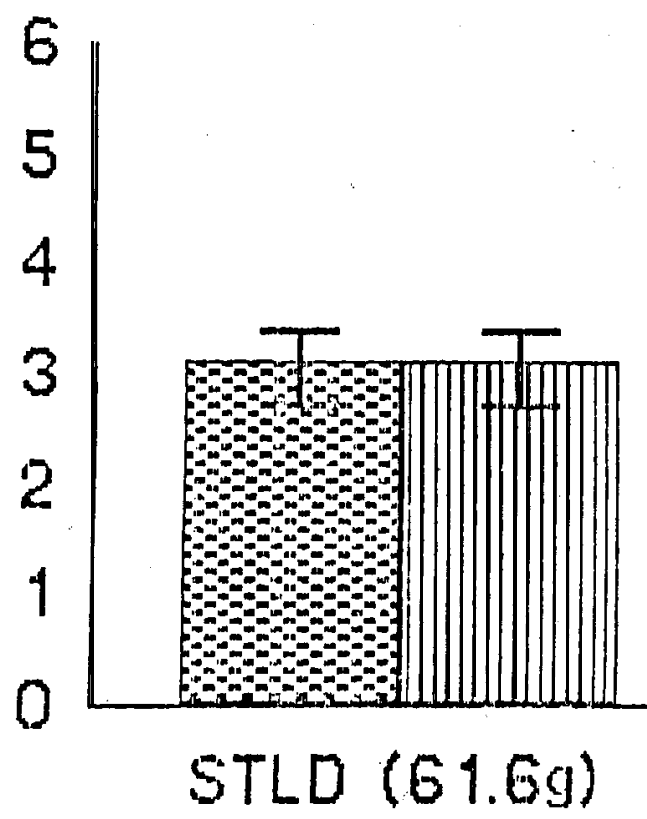

३ PIT

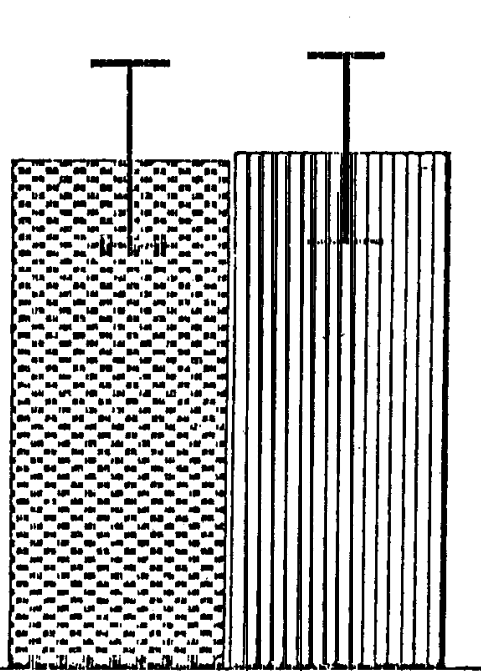

CHINOOK SALMON (8.6g)

Figure 4.- Comparison of pooled swimming stamina data for PIT-tagged and control chinook salmon and steelhead tested in a hatchery situation. Brackets indicate one standard deviation. Number in parenthesis indicates mean weight. 


\section{STRIDE EFFICIENCY}

\section{(TAIL BEATS/BODY LENGTH/SEC)}

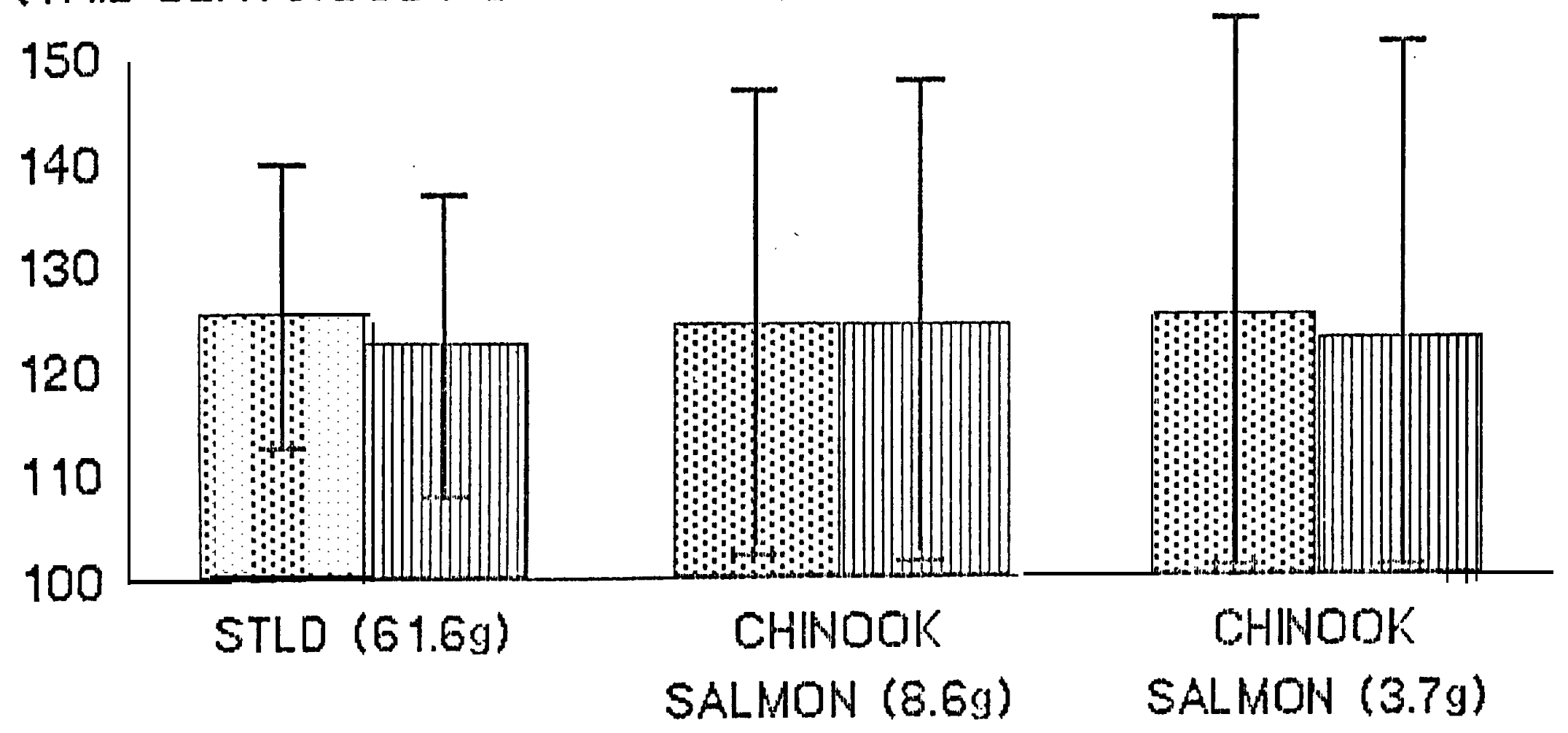

Figure 5.--Comparison of pooled stride efficiency data for PIT-tagged and control chinook salmon and steelhead tested in a hatchery situation ${ }^{\bullet}$ Brackets indicate one standard deviation. Number in parenthesis indicate mean weight. 




\section{EPIT TAGGED}


Table 9.--Swimming stamina, stride efficiency, and opercular
beat rate for in-river migrating fish tested at
McNary Dam.

\begin{tabular}{|c|c|c|c|c|c|}
\hline \multirow{2}{*}{$\begin{array}{l}\text { Species- } \\
\text { test group b }\end{array}$} & $\begin{array}{c}\text { Stride } \\
\text { efflciency_a }\end{array}$ & \multicolumn{2}{|c|}{$\begin{array}{l}\text { Opercular } \\
\text { beat rate a }\end{array}$} & \multicolumn{2}{|c|}{$\begin{array}{l}\text { Swimming } \\
\text { stamina }\end{array}$} \\
\hline & Mean. SD & Mean & $\mathrm{SD}$ & Mean & $\mathrm{SD}$ \\
\hline
\end{tabular}

\section{Steelhead}

\begin{tabular}{|c|c|c|c|c|c|c|}
\hline Control & 129.1 & 20.9 & 145.7 & 19.3 & 2.9 & 0.5 \\
\hline PIT & 125.8 . & 17.8 & 145.7 & 16.3 & 2.8 & 0.8 \\
\hline Brand & $128.4^{\prime}$ & 20.7 & 147.7 & 17.7 & 2.8 & 0.5 \\
\hline CWT & 123.3 & 15.4 & 146.6 & 16.3 & 2.9 & 0.6 \\
\hline \multicolumn{7}{|l|}{$\begin{array}{l}\text { Branded } \\
\text { (non-caudal clip) }\end{array}$} \\
\hline $\begin{array}{l}\text { B randed } \\
\text { (caudal clipped) }\end{array}$ & -- & -- & -- & -- & 2.8 & 0.4 \\
\hline \multicolumn{7}{|c|}{ Yearlins chinook salmon } \\
\hline Control & 131.8 & 23.8 & 125.0 & 7.5 & 3.2 & 0.7 \\
\hline $\mathrm{PIT}$ & 124.8 & 25.1 & 114.3 & $\mathrm{~L} 6.1$ & 3.4 & 0.8 \\
\hline Brand & 126.4 & 23.3 & 115.8 & 19.8 & 3.2 & 1.0 \\
\hline CWT & $122.0 *$ & 23.7 & 112.5 & 19.0 & 3.3 & 1.0 \\
\hline
\end{tabular}

Underyearling chinook salmon

\begin{tabular}{lllllll} 
Control & 129.6 & 35.6 & -- & -- & 5.2 & 1.2 \\
PIT & 125.3 & 33.0 & -- & -- & 5.2 & 1.4 \\
Brand & 125.4 & 32.1 & -- & -- & 5.4 & 1.3 \\
CWT & 125.8 & 33.5 & -- & -- & 5.5 & 1.3 \\
\hline
\end{tabular}

$\mathbf{a} *$ = significantly different from controls, $\mathrm{P}<0.05$

-- indicates no measurements documented.

b $n=30$ fish tested for each group. 


\section{SWIMMING STAM NA}

\section{(BODY LENGTHS/SEC)}

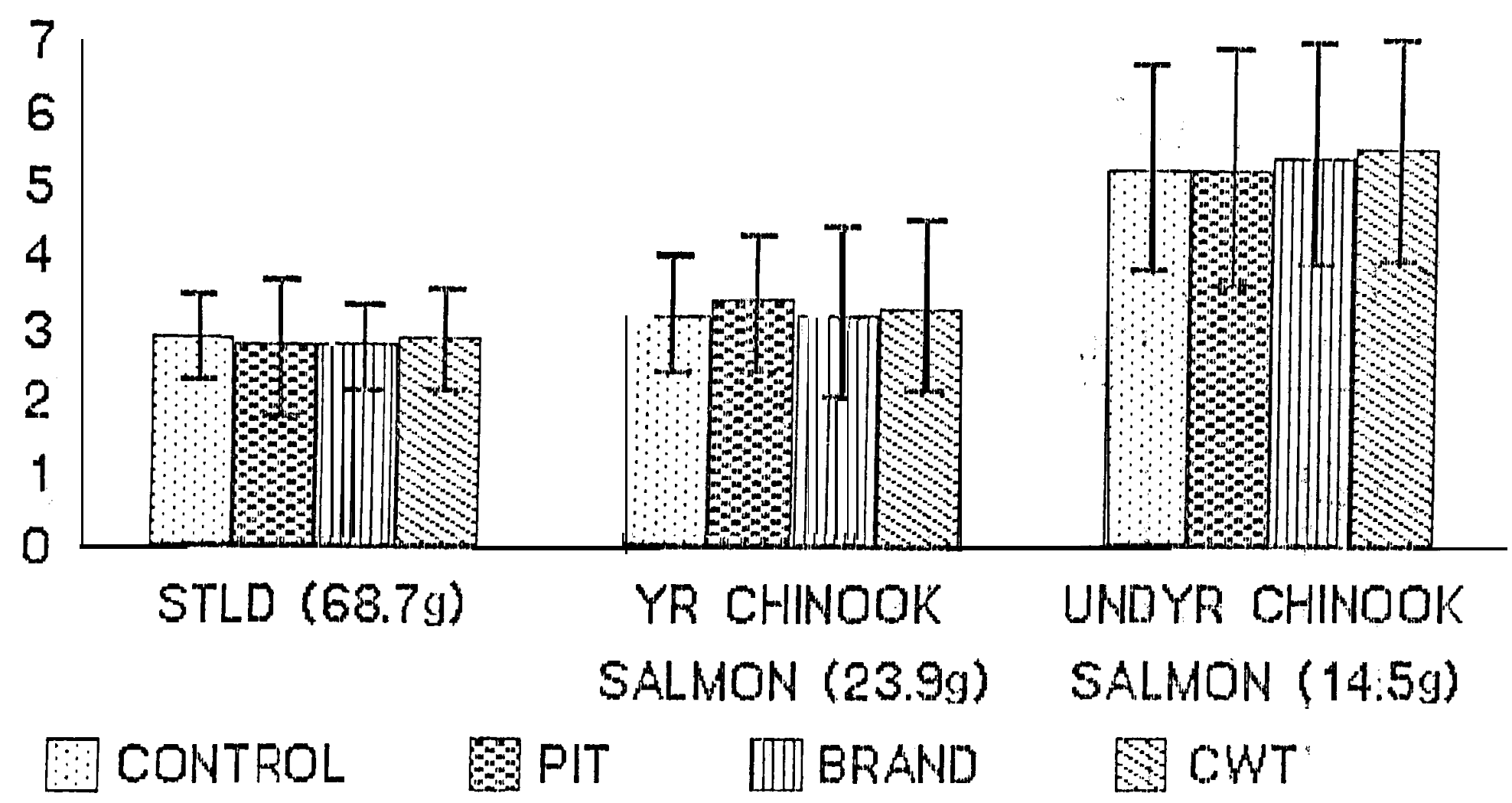

Figure 7. Comparison of swimming stamina of PIT-tagged, freeze branded, coded wire tagged (CWT), and control steelhead (STLD), and underyearling (UNDYR) and yearling (YR) chinook salmon tested at McNary Dam, 1986. Brackets indicate one standard deviation. Number in parenthesis indicates mean weight. 


\section{STRIDE EFFICENCY}

\section{(TAIL BEATS/BODY LENGTH/SEC)}

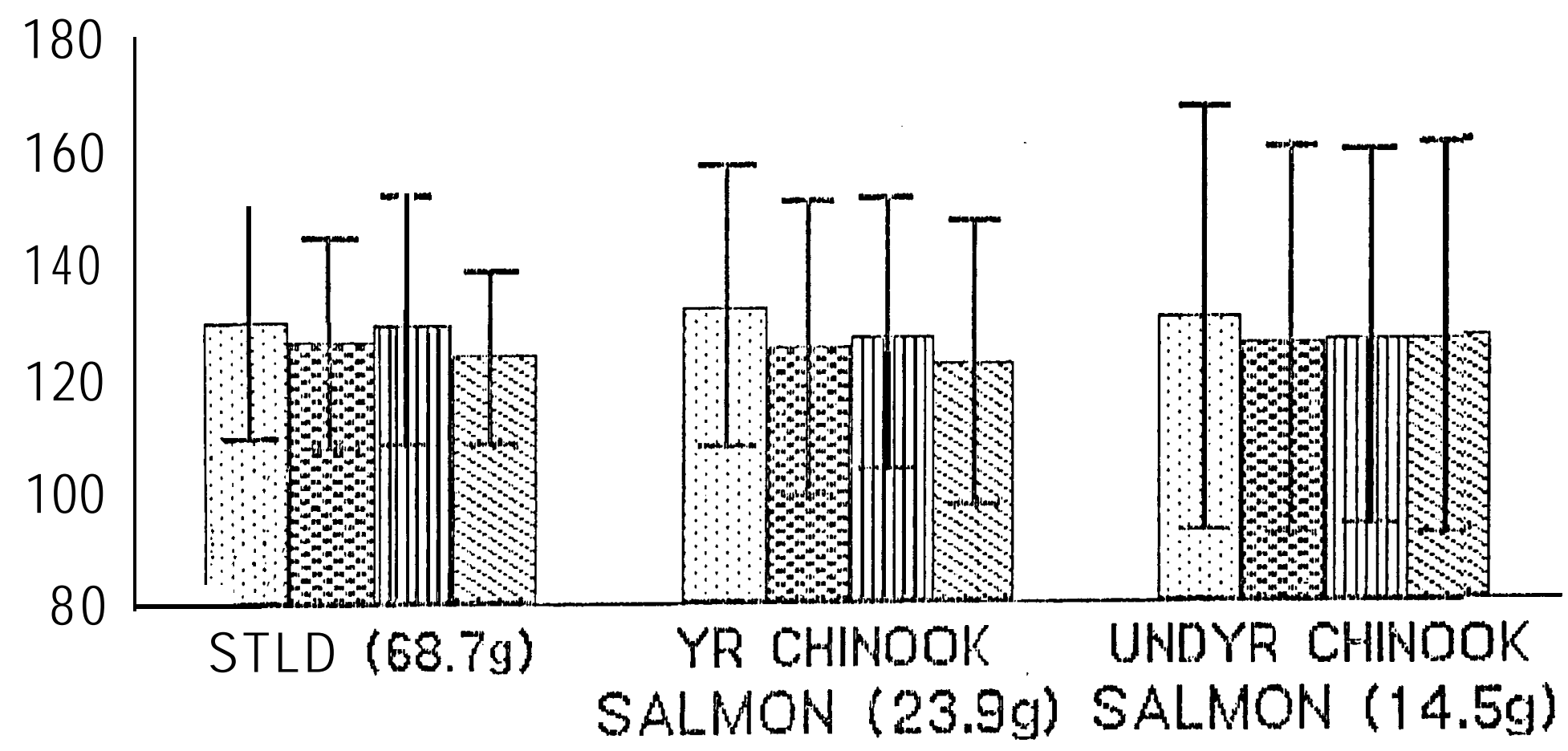

$\square$ CONTRL $\quad \square$ PIT $\quad$ IIIIBRAND $\quad$ CWT

Figure 8.--Comparison of stride efficiency of PIT-tagged, freeze branded, coded wire tagged (CWT), and control steelhead (STLD), and underyearling (UNDYR) and
yearling chinook (YR) salmon tested at McNary Dam, 1986. Brackets indicate one standard deviation. Number in parenthesis indicates mean weight. 


\section{AVERAGE RESPIRATORY RATE}

\section{(OPERCULAR BEATS/MINUTE)}

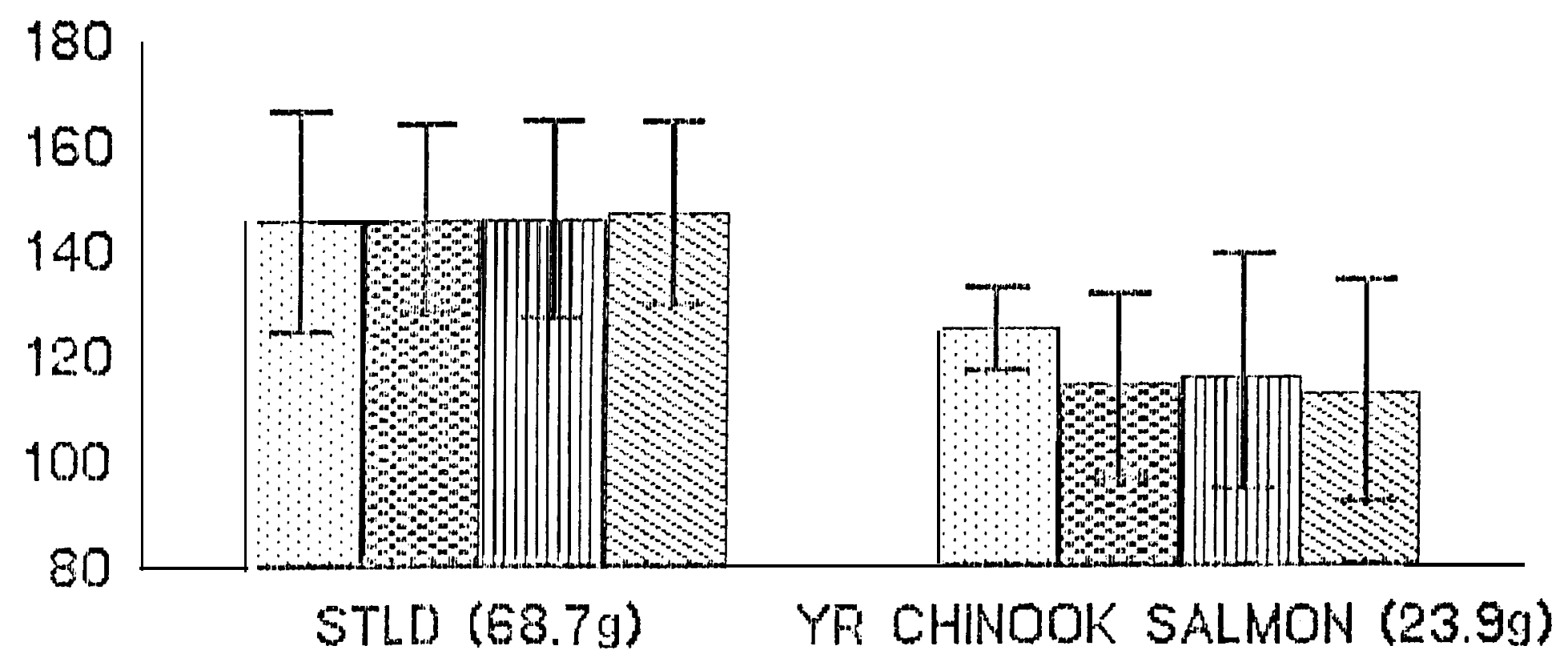

CONTROL $\quad$ IIII BRAND PIT CWT

Figure 9 -Comparison of respiratory rate of PIT-tagged, branded, CWT, and control steelhead (STLD) and yearling (YR) chinook salmon tested at McNary Dam, 1986. Brackets indicate one standard deviation. Number in parenthesis indicates mean weight. 
group was significantly $(P<0.05)$ different from controls in the yearling chinook salmon group (this difference was minor, and we do not believe it is of biological importance) (Table 9, and Figs. 7, 8, and 9).

Five-day post-test survival was statistically $(P<0.05)$ similar in all four treatments for each species tested (Table 10). In addition, in all cases, PIT tag retention was $100 \%$ during the 7 -d post-test holding period indicating that severe (swimming) exercise has no adverse influence on PIT tag retention of inriver migrating fish.

Swimming stamina was also compared between branded and caudal-clipped and branded and non-caudal-clipped fish, and no statistical difference $(P<0.05)$ was noted (Table 9 and Fig. 10). An important observation was that none of the currently used fish identification methods (freeze branding, upper caudal fin clipping, coded wire tagging, and PIT tagging) have a biologically important impact onthe swimming ability of any species tested.

In summary, during 1985 (Prentice et al. 1986) and 1986 (this study) the abilities of over 726 PIT-tagged fish were assessed through swimming performances tests (Fig. 3). This work included measurements on several size ranges of spring chinook salmon, steelhead, and fall chinook salmon in both in-hatchery and in-river (migrating) situations. In no case did the PIT tag have an adverse effect on the fish. Therefore, we feel confident that the PIT tag should have no influence on the (migratory related) swimming ability of salmonids.

\section{Conclusions and Recommendations}

1. The glass-encapsulated PIT tag is better than the polypropylene-encapsulated PIT tag from both a technical and biological standpoint. 
Table 10.--Five-day post fatigue test survival for in-river migrating fish tested at McNary Dam in 1986.

\begin{tabular}{lcccc}
\hline & \multicolumn{4}{c}{ Survival $(\%)$ a } \\
\cline { 2 - 5 } Species & $\begin{array}{c}\text { PIT } \\
(\mathrm{n}=30)\end{array}$ & $\begin{array}{c}\text { Brand } \\
(\mathrm{n}=30)\end{array}$ & $\begin{array}{c}\text { CWT } \\
(\mathrm{n}=30)\end{array}$ & $\begin{array}{c}\text { Control } \\
(\mathrm{n}=30)\end{array}$ \\
\hline $\begin{array}{l}\text { Yearling chinook } \\
\text { salmon }\end{array}$ & 56.7 & 63.3 & 60.0 & 63.3 \\
$\begin{array}{l}\text { Steelhead } \\
\begin{array}{l}\text { Underyearling } \\
\text { chinook salmon }\end{array}\end{array}$ & 70.0 & 66.7 & 66.7 & 70.0 \\
& 30.0 & 26.7 & & 26.7 \\
\hline
\end{tabular}

a PIT indicates PIT-tagged fish, Brand indicates freeze branded fish, CWT indicates coded-wire-tagged fish, and Control indicates handled but unmarked fish. 


\section{SWIMMING SPEED}

\section{(body lengths/sec)}

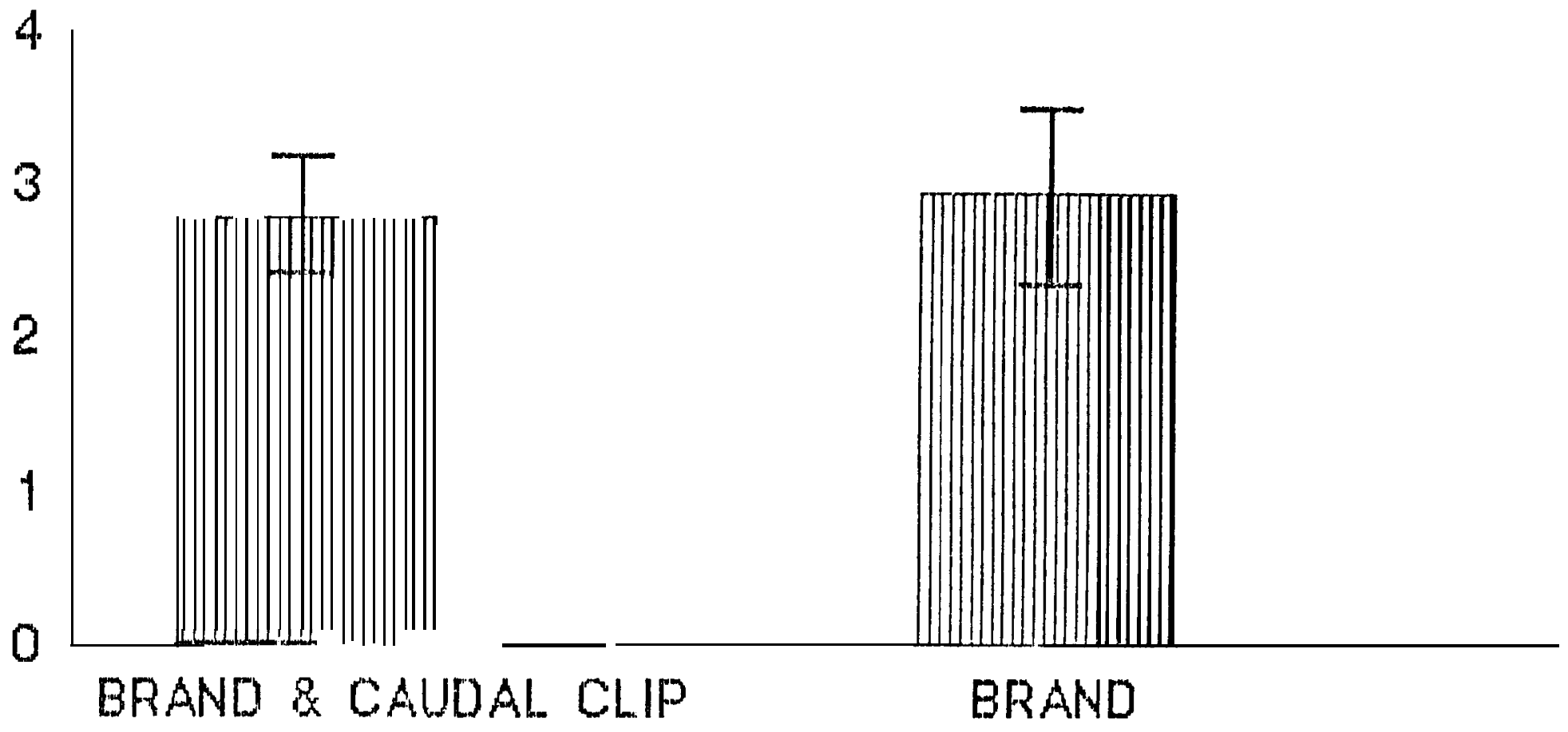

TREATMENT

Figure 10.--Comparison of swimming stamina of upper caudal fin-clipped and non-fin॰clipped steelhead tested at McNary Dam, 1986. Brackets indicate one standard eeviation. 
2. Survival of PIT-tagged salmonids weighing greater than $5 \mathrm{~g}$ (mean weight) in a nonsmolting and disease free condition will be near $100 \%$ However, smaller fish or those undergoing smoltification or diseased may exhibit minimal (usually less then 5\%) mortality.

3. The glass-encapsulated PIT tag does not cause adverse tissue reaction in juvenile chinook salmon or steelhead.

4. PIT tags normally do not migrate from the area of implant.

5. Tag retention in juvenile salmonids exceeds $99 \%$.

6. Active swimming does not affect tag retention in juvenile chinook salmon or steelhead (100\% tag retention in all tests).

7. Neither the PIT tag nor traditional tags and marks (e.g., coded wire tags and cold brands) significantly affect swimming behavior or ability of juvenile salmonids.

8, The operational life of the new glass-encapsulated PIT tag is excellent, with $100 \%$ of the tags still operating after $400+$ days of operation in fish.

9. The glass-encapsulated version of the PIT tag is developed to a point where it can be considered for use by agency managers and researchers in tagging studies. These initial studies should, however, be relatively small scale until all equipment necessary for automated tagging and monitoring at release can be evaluated. 
FIELD STUDIES

Reliability of Juvenile PIT Tag Monitors at Lower Granite and McNary Dams

Introduction

Prototype juvenile PIT tag monitoring equipment was evaluated under field conditions at McNary Dam in 1985 (Prentice et al. 1986). Similar methods were used to determine the reliability of juvenile PIT tag monitoring stations installed at Lower Granite and McNary dams during the 1986 field season. The equipment was operated continuously to ensure the accuracy and reliability of the collected data and to determine areas for design improvement.

Methods and Materials

The first study site was located at Lower Granite Dam on the Snake River approximately $54 \mathrm{~km}$ down river from Clarkston, Washington (Fig. 11). six juvenile PIT tag monitors were installed in pairs within three fish discharge flumes and pipes of the juvenile wet separator (Fig. 12). All the monitors were $122 \mathrm{~cm}$ long. However, due to the various shapes of flumes and pipes within the bypass system, the monitors were custom fit to replace existing flumes and pipes. Monitors $\mathrm{A}$ and $\mathrm{B}$ were $25.4 \mathrm{~cm}$ in diameter, and Monitors $\mathrm{C}$ through $\mathrm{F}$ were $15.2 \mathrm{~cm}$ high by $45.7 \mathrm{~cm}$ wide.

The second study site was located at McNary Dam on the Columbia River near Umatilla, Oregon (Fig. 11). Six juvenile PIT tag monitors were also installed in pairs within the fish discharge flumes of the juvenile wet separator (Fig. 13). The McNary monitors were all $122 \mathrm{~cm}$ long and $15.2 \mathrm{~cm}$ high. Monitors A and $B$ were $25.4 \mathrm{~cm}$ wide, Monitors $\mathrm{C}$ and $\mathrm{D}$ were $35.5 \mathrm{~cm}$ wide, and Monitors $\mathrm{E}$ and $\mathrm{F}$ were $45.7 \mathrm{~cm}$ wide. 


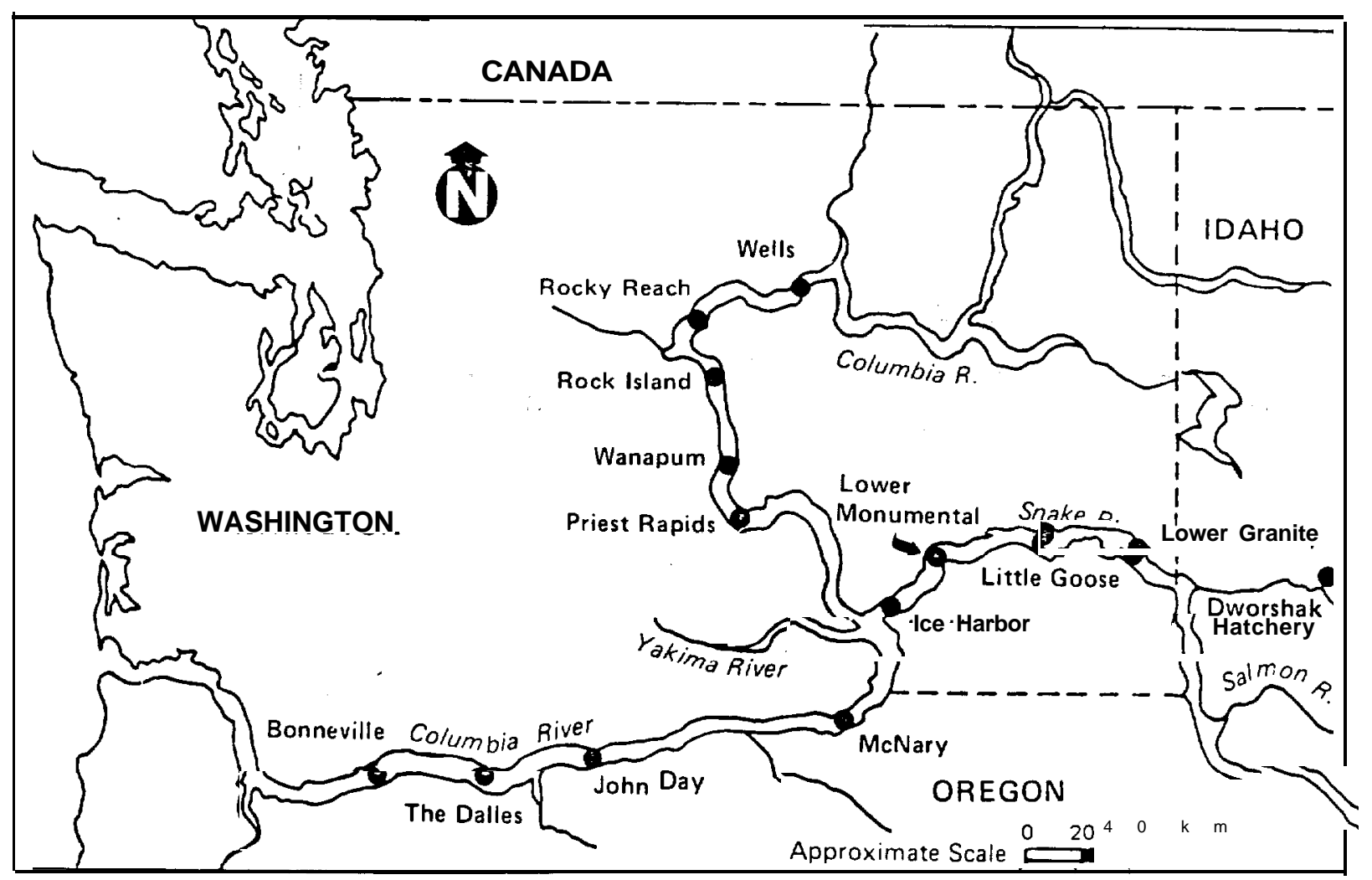

Figure 11.--PIT tag study area, 1986. 


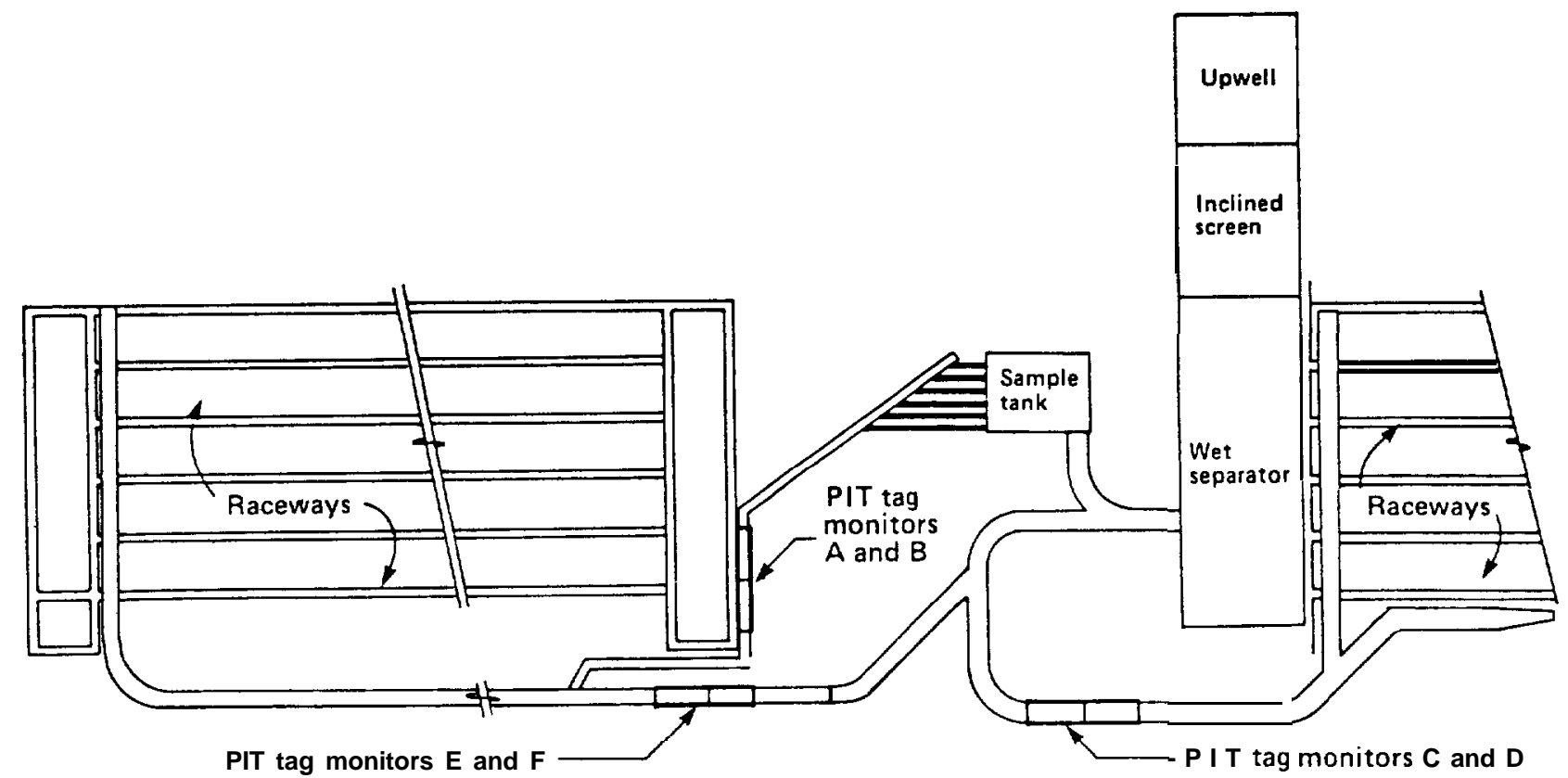

Figure 12.--Overview of the Lower Granite Dam fish separator and raceways showing the location of PIT tag monitors in 1986. 


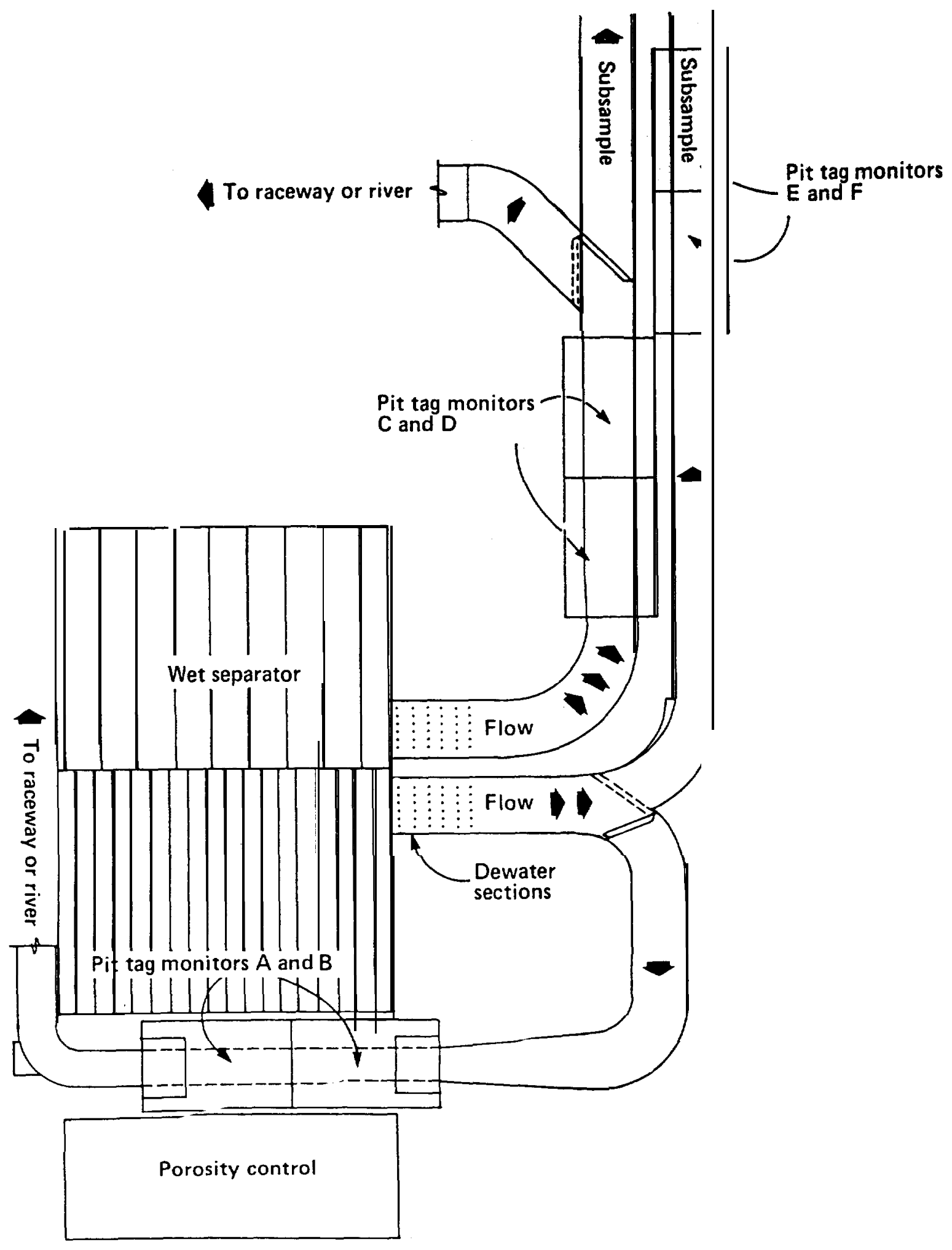

Figure 13.--overview of the McNary Dam fish separator and raceways showing the location of PIT tag monitors in 1986. 
All monitors at both dams were constructed with the following: 1) an aluminum shield to eliminate errant rad 10 emiss Ions and provide weather protection, 2) two tag detection loops, and 3) a dual exciter within the shielding. In addition, each monitor had Its own remotely located power supply. The wiring scheme at both locations provided two sub-systems\&to provide backup In case of electrbnlc failure. The exciters of Monitors A, $C$, and $E$, the upstream sub-system, were connected to an individual controller unit and printer whereas Monitors $\mathrm{B}, \mathrm{D}$, and $\mathrm{F}$ were connected to similar equipment and called the downstream subsystem. Both sub-systems were connected to a computer through a multi-port controller and were on separate electrical breakers. The computer and both controllers were powered through a battery backup system (Fig. 14).

We operated at Lower Granite Dam from 6 April to 15 July 1986 and at McNary Dam from 14 April to 28 september 1986. To evaluate the operational longevity of the electronic components, they were operated continually during the study. Tag reading reliability tests were conducted monthly--four tests per pair of monitors at Lower Granite Dam (Table 11) and six tests per pair of monitors at McNary Dam (Table 12). Each, test consisted of releasing neutrally buoyant plastic fishing bobbers $(5.8 \mathrm{~cm}$ long by $2.5 \mathrm{~cm}$ in diameter) containing a functional PIT tag. The bobbers, connected with a line, were released into' the entrance of each monitor for the first trial and then retrieved back through for the next trial.

Results and Discussion

The monitoring equipment performed satisfactorily during the 1986 field season with only four minor electronic equipment problems. All repairs were made in the field within $1 \mathrm{~h}$ of discovery. However, a software problem was detected which required revision by the manufacturer. 


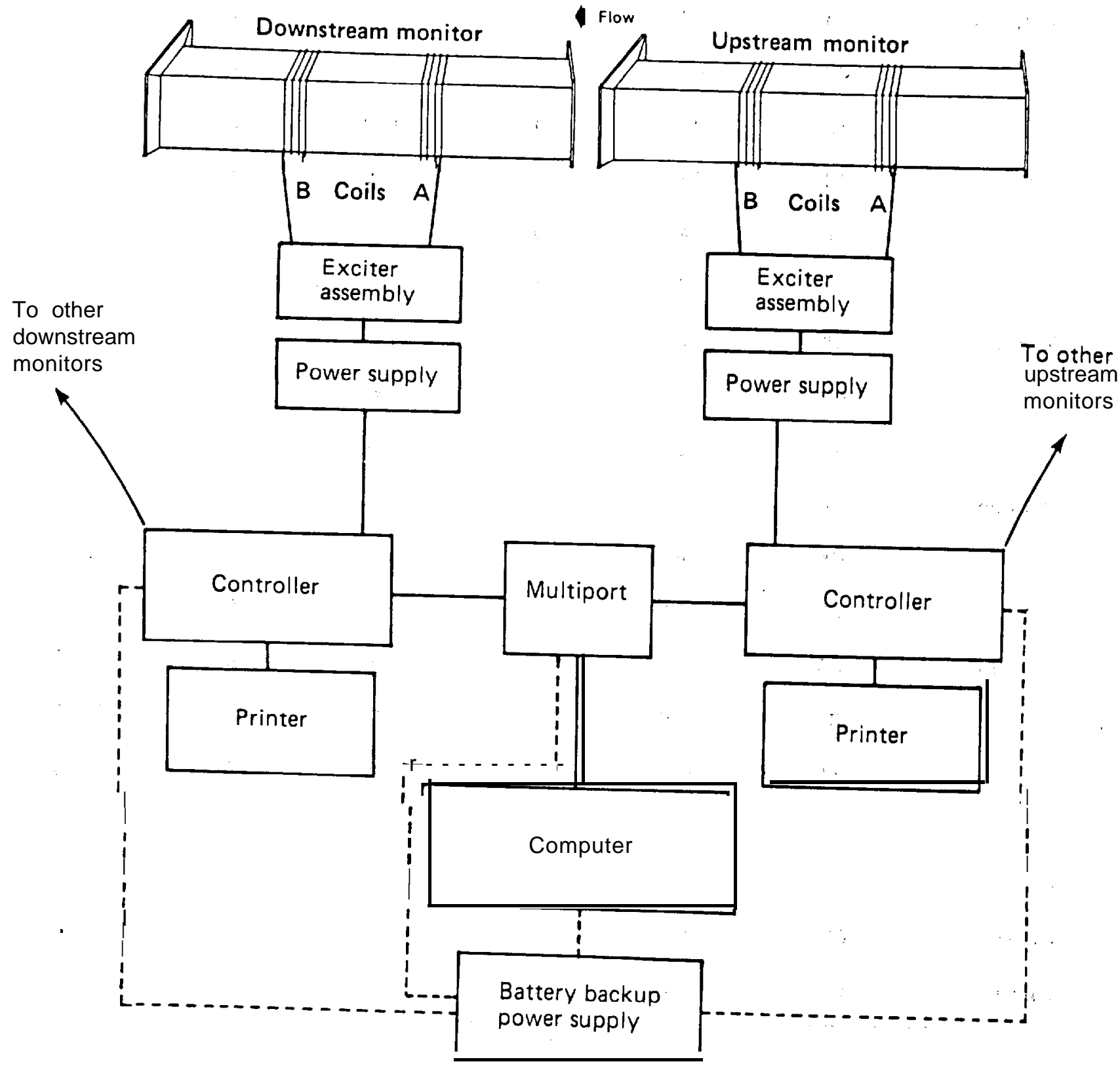

Figure 14.--Diagram of PIT tag monitor system installed at Lower Granite and McNary dams in 1986. 
Table $11 .--$ Summary of reliability test conducted at Lower Granite Dam, 1986.

\begin{tabular}{|c|c|c|c|c|c|c|}
\hline \multirow[b]{2}{*}{ Test date } & \multirow[b]{2}{*}{ Monitors } & \multirow{2}{*}{$\begin{array}{l}\text { Total } \\
\text { number } \\
\text { of tags }\end{array}$} & \multirow{2}{*}{$\begin{array}{l}\text { Number } \\
\text { of tags } \\
\text { not read }\end{array}$} & \multirow{2}{*}{$\begin{array}{l}\text { Percent } \\
\text { tags } \\
\text { read }\end{array}$} & \multicolumn{2}{|c|}{ Tag reading errors } \\
\hline & & & & & Number & Percent \\
\hline \multirow[t]{3}{*}{9 April } & $A B$ & 121 & 1 & 99 & 3 & 2.5 \\
\hline & $\mathrm{CD}$ & --- & - & --- & - & \\
\hline & $\mathrm{EF}$ & 221 & 0 & 100 & 5 & 2.3 \\
\hline \multirow[t]{3}{*}{6 May } & $A B$ & 121 & 0 & 100 & 3 & 2.5 \\
\hline & CD & 40 & 0 & 100 & 3 & 7.5 \\
\hline & $\mathrm{EF}$ & 101 & 1 & 99 & 0 & 0 \\
\hline \multirow[t]{3}{*}{7 May } & $\mathrm{AB}$ & 101 & - & 100 & 0 & 0 \\
\hline & $C D$ & 60 & 1 & 98 & 0 & 0 \\
\hline & $\mathrm{EF}$ & 121 & 0 & 100 & 2 & 1.6 \\
\hline \multirow[t]{3}{*}{3 June } & $\mathrm{AB}$ & --- & - & --- & - & \\
\hline & $\mathrm{CD}$ & 60 & 0 & 100 & 9 & $15-0$ \\
\hline & $\mathrm{EF}$ & 91 & 0 & 100 & 0 & 0 \\
\hline \multirow[t]{3}{*}{1 July } & $A B$ & 121 & 1 & 99 & 4 & 3.3 \\
\hline & CD & 50 & 0 & 100 & 6 & 12.0 \\
\hline & $\mathrm{EF}$ & 100 & 1 & 99 & 2 & 2.0 \\
\hline Total & $A B$ & 464 & 2 & 99.6 & 10 & 2.2 \\
\hline Total & CD & 150 & 1 & 99.3 & 19 & 12.7 \\
\hline Total & $\mathrm{EF}$ & 634 & 2 & 99.7 & 9 & 1.4 \\
\hline
\end{tabular}


Table 12 .--Summary of reliability test conducted at McNary Dam, 1986.

\begin{tabular}{|c|c|c|c|c|c|c|}
\hline \multirow[b]{2}{*}{ Test date } & \multirow[b]{2}{*}{ Monitors } & \multirow{2}{*}{$\begin{array}{l}\text { Total } \\
\text { number } \\
\text { of tags }\end{array}$} & \multirow{2}{*}{$\begin{array}{l}\text { Number } \\
\text { of tags } \\
\text { not read }\end{array}$} & \multirow{2}{*}{$\begin{array}{l}\text { Percent } \\
\text { tags } \\
\text { read }\end{array}$} & \multicolumn{2}{|c|}{ Tag reading errors } \\
\hline & & & & & Number & Percent \\
\hline \multirow[t]{3}{*}{14 April } & $\mathrm{AB}$ & 201 & 2 & 99 & 1 & 0.5 \\
\hline & $\mathrm{CD}$ & 241 & 5 & 98 & 1 & 0.4 \\
\hline & $\mathrm{EF}$ & 201 & 1 & 99 & 1 & 0.5 \\
\hline \multirow[t]{3}{*}{30 May } & $\mathrm{AB}$ & 91 & 0 & 100 & 1 & 1.1 \\
\hline & $\mathrm{CD}$ & 126 & 2 & 98 & 0 & 0 \\
\hline & $\mathrm{EF}$ & 91 & 0 & 100 & 1 & 1.0 \\
\hline \multirow[t]{3}{*}{23 June } & $\mathrm{AB}$ & 109 & 0 & 100 & 0 & 0 \\
\hline & $\mathrm{CD}$ & 50 & 0 & 100 & 0 & 0 \\
\hline & $\mathrm{EF}$ & 101 & 0 & 100 & 1 & 1.0 \\
\hline \multirow[t]{3}{*}{25 June } & $A B$ & 101 & 0 & 100 & 0 & 0 \\
\hline & $\mathrm{CD}$ & 100 & 1 & 99 & 1 & 1.0 \\
\hline & $\mathrm{EF}$ & 100 & 1 & 99 & 2 & 2.0 \\
\hline \multirow[t]{3}{*}{$17 \mathrm{July}$} & $\mathrm{AB}$ & 101 & 0 & 100 & 0 & 0 \\
\hline & $\mathrm{CD}$ & 61 & 1 & 98 & 0 & 0 \\
\hline & $\mathrm{EF}$ & 101 & 1 & 99 & 0 & 0 \\
\hline \multirow[t]{3}{*}{9 September } & $\mathrm{AB}$ & 121 & 0 & 100 & 0 & 0 \\
\hline & $\mathrm{CD}$ & 121 & 0 & 100 & 0 & 0 \\
\hline & $\mathrm{EF}$ & 242 & 1 & 99 & 0 & 0 \\
\hline Total & $A B$ & 724 & 2 & 99.7 & 2 & 0.3 \\
\hline Total & CD & 699 & 9 & 98.7 & 2 & 0.3 \\
\hline Total & $\mathrm{EF}$ & 836 & 4 & 99.5 & 4 & 0.5 \\
\hline
\end{tabular}


The first equipment problem occurred at Lower Granite Dam when the computer's internal power supply malfunctioned. A spare computer was installed the following day. Since the data were stored both on a printer and on a computer file, no data were lost. The second problem occurred at Lower Granite Dam when the master breaker to the PIT tag detection system was tripped by an air conditioner in another building and $16 \mathrm{~h}$ of data were lost. Subsequently, the problem was avoided by Installing the system on an Individual circuit breaker. The third Incident occurred when a switch for the downstream controllers at Lower Granite Dam was accidentally switched off. Since the monitors at the dam were configured into two completely independent sub-systems (upstream and downstream), no data were lost. Consequently, the sub-system became a built in backup system. The fourth problem was the failure of the exciter units In Monitors $\mathrm{E}$ and $\mathrm{F}$ at McNary Dam. This problem occurred on four separate occasions but never in both the upstream and downstream systems simultaneously. The two problem monitors ( $E$ and $F$ ) were located on the subsample flume. This flume was dewatered $90 \%$ of the time, and the detectors were tuned for maximum water flow. Therefore, during the dewatered time, a power overload occurred which eventually overheated the circuitry. The problem was temporarily corrected In the field by replacing the exciter unit with a spare. The manufacturer is currently researching a power limiting system to prevent future problems.

Results of the monthly tag reading efficiency tests (percentage of tags detected) are shown in Table 11 for Lower Granite Dam and Table 12 for McNary Dam. The percentage of tags read by any pair of detectors was never less than 98\% at either station, and the overall detection rate at both locations exceeded 99\%. These results surpass the goal of $95 \%$ set at the start of the project. 
During reliability testing, 8 tag reading errors at McNary Dam and 38 at Lower Granite Dam were detected. Detectors C and D accounted for $50 \%$ of the errors at Lower Granite Dam. The errors at Lower Granite Dam were caused by leaving Detectors $C$ and $D$ running with partial power because the flume in which they were installed was used only twice during the field season. The partial power mode helped reduce the risk of damage to the electronics by overheating.

Tag reading errors occurred mostly during reliability testing when several tags passed through the detector loops at the same time due to a fouled test-tag string. In addition, tags remaining within the outer fringe of the reading area for more than several seconds occasionally were misread. To our knowledge, this occurred only during rellabllity testing. In all cases, misread tags were read correctly in subsequent coils. To correct misreading problems, the manufacturer reprogrammed the software to require each tag to be read twice correctly by one coil prior to writing to the file. A test conducted at McNary Dam after the modifications indicated no misreading problems, however, additional tests of the double-read software are required to verify its reliability.

Tag Reading Efficiency of Juvenile Pit Tag Monitors at Lower Granite and McNary Dams

Introduction

Juvenile PIT tag monitors were evaluated for tag reading efficiency under field conditions in 1985 at McNary Dam (Prentice et al. 1986). For the evaluation, live fish were released directly into the wet separator above the detectors and $97.1 \%$ of the yearling chinook salmon and $92.5 \%$ of the underyearling chinook salmon were detected.

To increase detection efficiency, the McNary Dam monitoring system was upgraded electronically in 1986. In addition, a PIT tag detection system was 
installed at Lower Granite Dam. Therefore, the PIT tag reading efficiencies of both systems were evaluated with live fish during the 1986 field season using the glass-encapsulated PIT tag. The behavior of the PIT-tagged fish is also discussed.

Methods and Material

Two PIT tag monitor stat ions were tested, one at the juvenile salmonid collection facility at McNary Dam and one at Lower Granite Dam (Figs. 11, 12, 13, and 14).

Two tests were conducted at Lower Granite Dam; yearling chinook salmon were evaluated on 11 and 12 April and steelhead on 5 and 6 May 1986. Three tests were conducted at McNary Dam: yearling chinook salmon on 9 and 10 May, steelhead on 17 and 18 May, and underyearling chinook salmon on 26 and 27 June 1986. At both facilities, sub-samples of fish passing through the collection system were diverted into an inspection room where they were dipnetted and inspected for fin clips, descaling, injuries, species, and brands. Only fish having limited scale loss and no previous marks, tags, or injuries were used in a given study. The fish were PIT-tagged by the method described in Appendix A. Twenty-five groups of twenty fish were tagged and measured to the nearest $3 \mathrm{~mm}$ (fork length). A $10 \%$ sub-sample was weighed to the nearest $0.5 \mathrm{~g}$. The data for each fish were automatically entered on a computer file as described earlier in this report, Each test group was held in a covered 132-liter portable container with a continuous supply of aerated ambient river water.

The fish were held for $24 \mathrm{~h}$ then released directly into the upwells of the wet separators (Figs. 12 and 13). Prior to release? each group was examined for tag loss and mortality. All mortalities were replaced with fish from the 25th group of fish, and fish remaining in this group were not used in the evaluation. 
The individual code and length of the replacement fish were substituted for the removed mortalities. Therefore, each of the 24 release containers had 20 fish, for a total of 480. Two groups were released at 30-min intervals until all 24 groups were placed into the wet separator.

All fish were allowed to pass through the wet separator on their own volition. During their exit from the wet separator, all fish were passively interrogated for tag presence. Upon detection of a PIT-tagged fish, the PIT tag codes were automatically recorded by the detection system. The code of each PIT tag, monitor and detection loop position, time of passage (day, hour, minute, and second), and date of passage (month, day, and year) were recorded into a computer and printer file. Reading efficiency was compared between replicates and test groups using the $\mathrm{G}^{2}$-statistic (Sokal and Rohlf 1981). A goal of $95 \%$, or better, detection efficiency was established.

Results and Discussion

Detection efficiency ranged from 96.0 to over $99.0 \%$ intests at both dams using live fish injected with glass PIT tags (Table 13 and Fig. 15). In all cases, these results exceeded our goal of 95\% detection efficiency. Of the 2,260 fish released 2,205 were detected, for an overall detection efficiency of 97.6\%. There was no statistical difference $(P<0.05, d f=4)$ in detection efficiency between groups for any species tested at either dam. During the yearling chinook salmon tests at Lower Granite Dam, the wet separator flooded resulting in a water overflow that allowed fish to bypass the detection system. This problem affected the first eight release groups. Consequently, this test was evaluated using Releases 9 through 25 only (17 groups).

In all tests, 95\% or more of the fish released exited the wet seperator within the first $10 \mathrm{~h}$ (Figs. 16 and 17). However, passage time varied 
Table 13.--Summary of efficiency tests conducted at McNary and Lower Granite dams in 1986 using chinook salmon and steelhead.

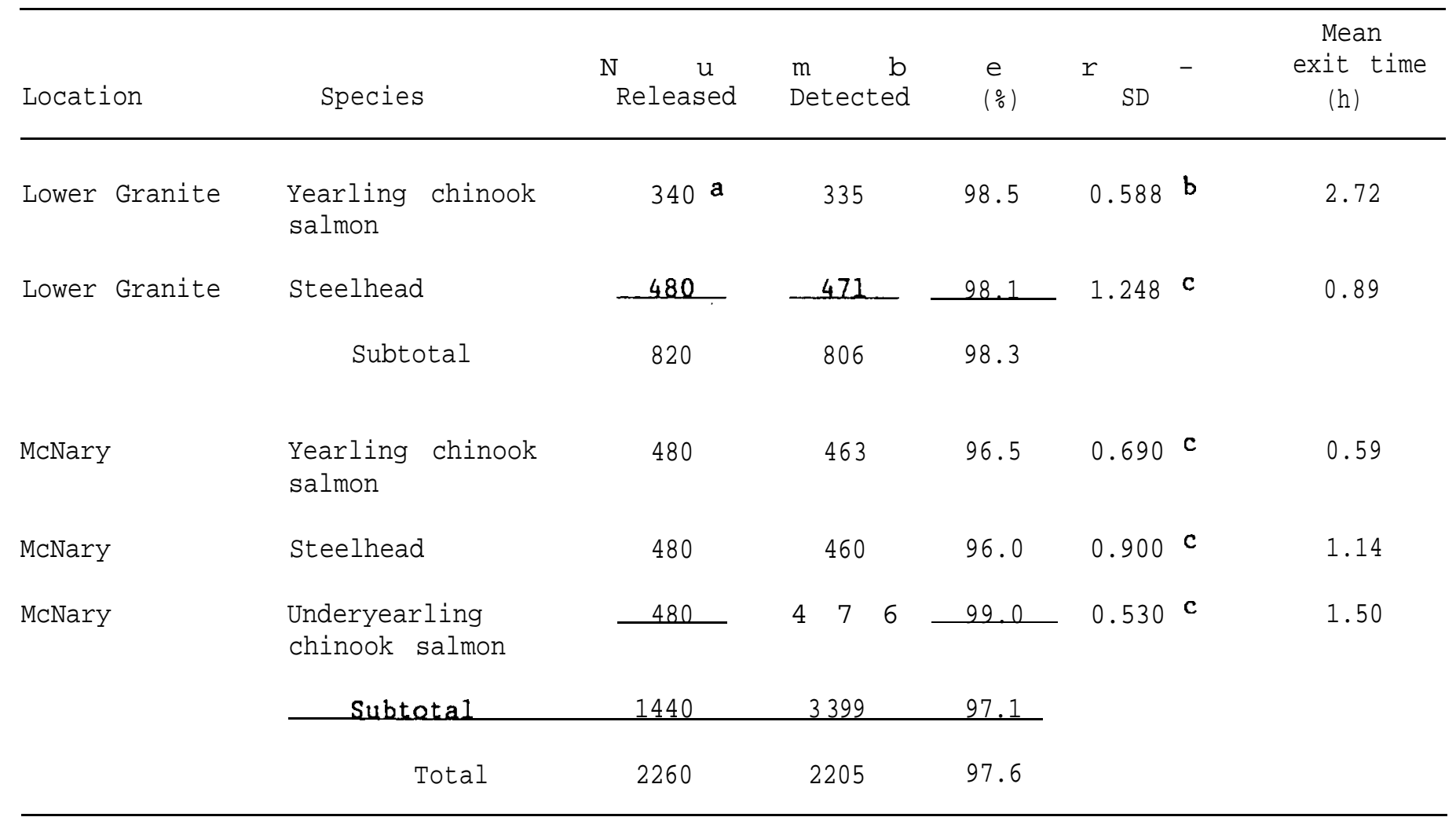

a Only 17 of 24 groups of fish were used in the test because of fish being able to bypass the detection system due to a wet seperator failure.

b $n=17$

c $\mathbf{n}=20$ 


\section{(\%) RECAPTURE}

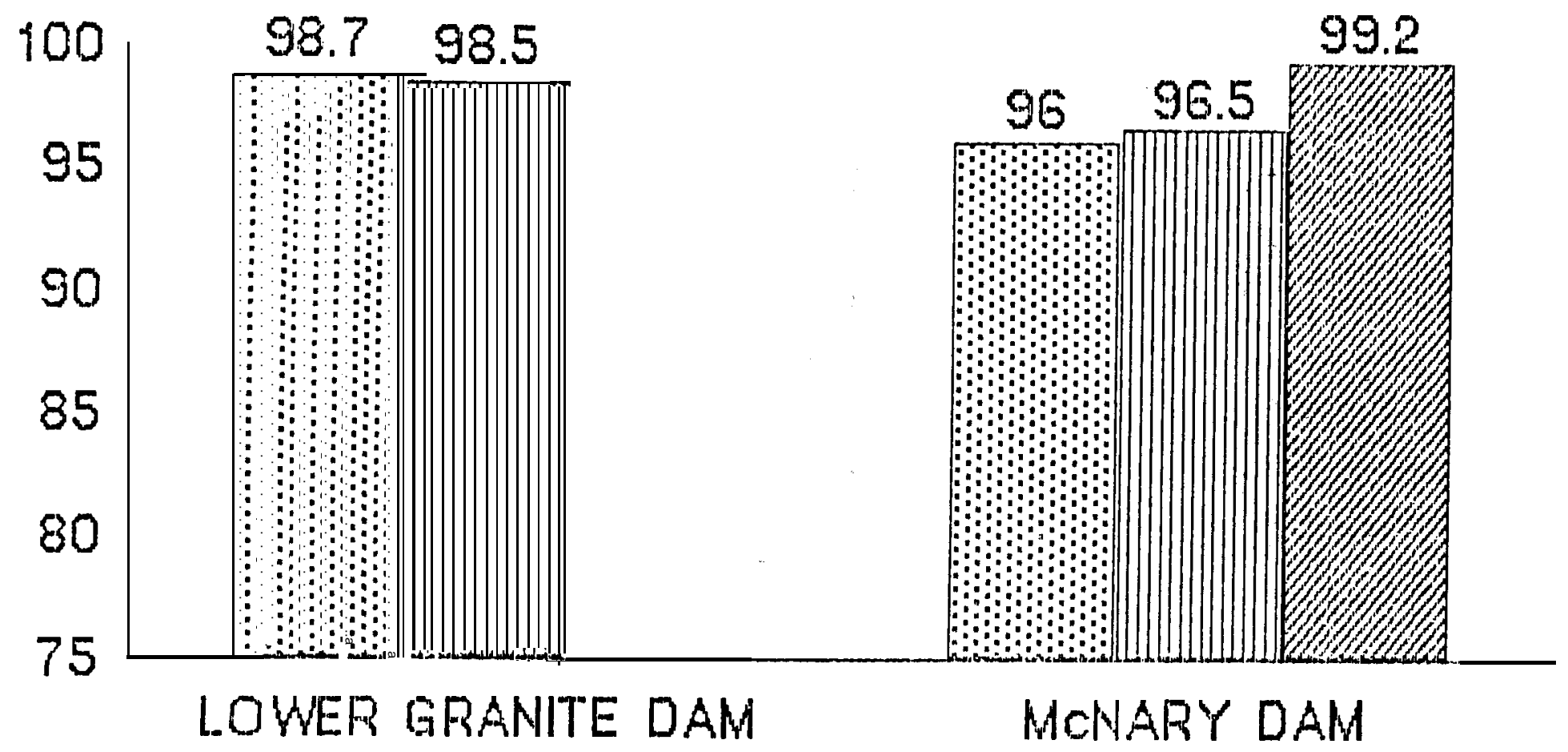

STEELHEAD

UNDERYEARLING CHINOOK

IIII YEARLING CHINOOK

Figure c5 -Detection of fish released into the wet separator at Lower Granite and McNary dams to evalcuate PIT tag monitors, 1986 


\section{McNary}

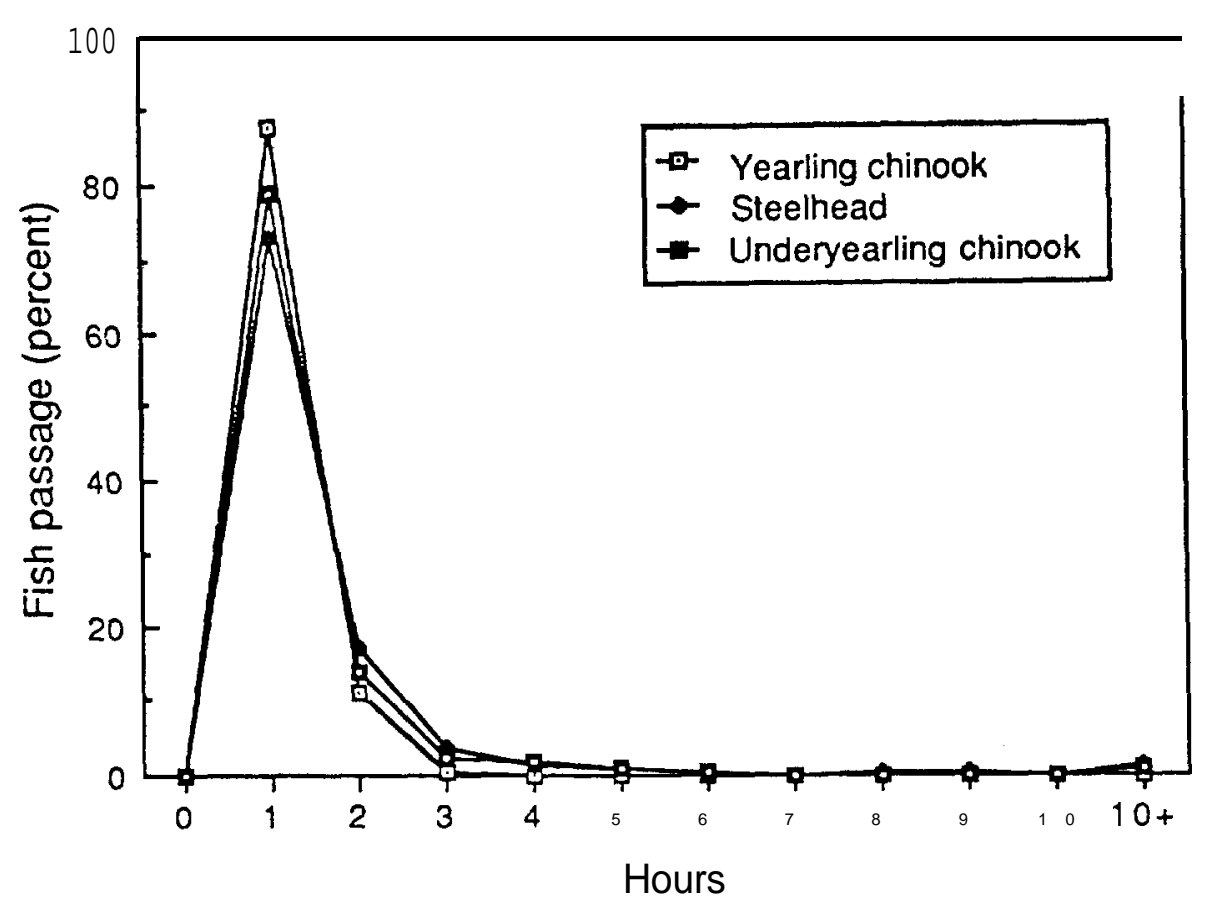

Figure 16.--Percentage of PIT-tagged underyearling and yearling chinook salmon and steelhead detected per hour exiting the McNary Dam wet separator, 1986. 


\section{Lower Granite}

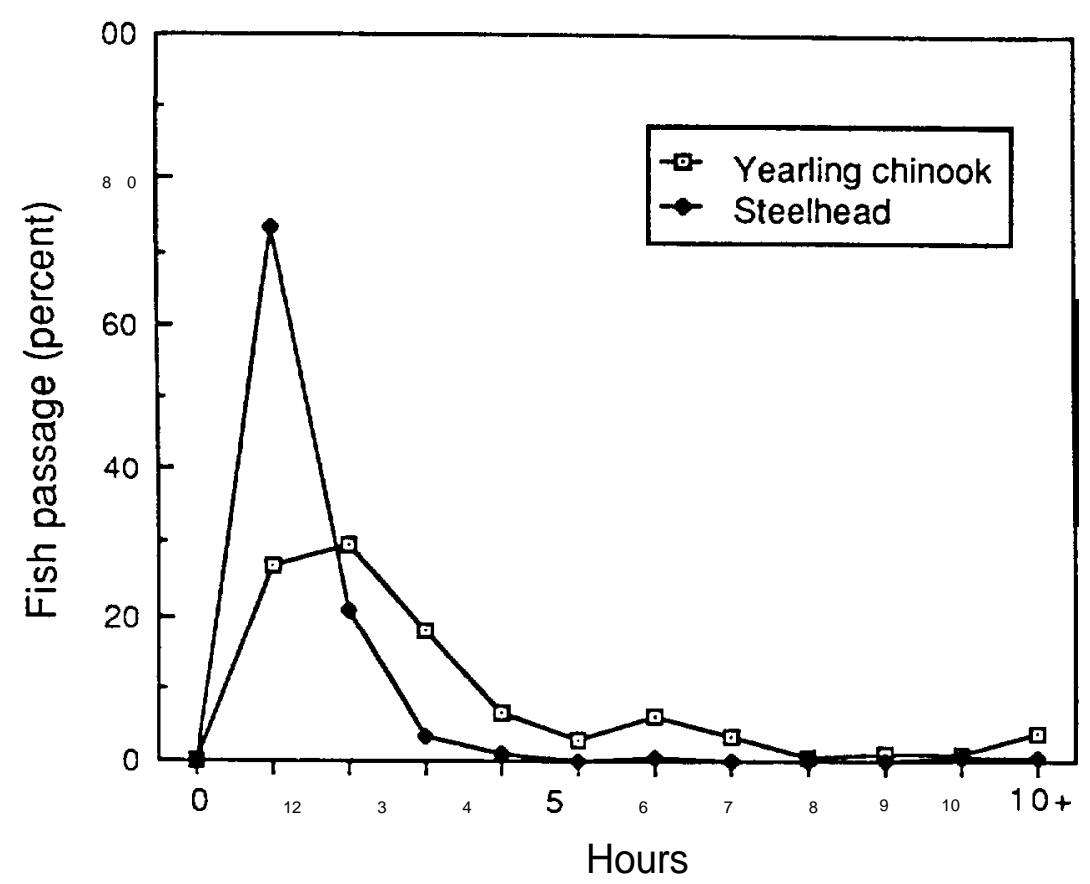

Figure 17.--Percentage of PIT-tagged yearling chinook salmon and steelhead detected per hour exiting the Lower Granite Dam wet separator, 1986. 
tremendously, ranging from less than 10 seconds for the first fish (in the yearling chinook salmon and steelhead tests) to $175.12 \mathrm{~h}$ for the last fish (in the underyearling chinook salmon test). Average passage time was also not consistent between species or dams and ranged from 0.59 to $2.72 \mathrm{~h}$ (Table 13). The efficiency test for yearling chinook salmon conducted at McNary Dam in 1985 (Prentice et al. 1986) showed exit times similar to those observed in 1986. Because so many factors could account for variations in the exit times (i.e., river flow, temperature, smoltification status, etc.), no explanation is offered for these differences.

Our PIT tag detection efficiency tests indicate that a high rate of detection can be expected for live (tagged) fish passing through detection systems incorporated into wet separators at fish collection facilities at hydroelectric dams. In addition, these tests suggest there are factors (environmental or physiological/behavioral) that may influence fish movement rates through a wet separator.

\author{
PIT-tagged Fish Compared to Branded \\ Fish from Dworshak National Fish Hatchery
}

Introduction

The migration characteristics of juvenile salmonids within the Columbia River system have been studied annually since 1964 (Raymond 1974). Groups of fish are normally marked (either at the hatchery or in-river), released, and then sampled at the collector dams. Freeze branding has been the traditional method used to identify these groups of fish (Park and Ebel 1974). However, branding requires the release of large numbers of fish and the physical handling of each recovered fish to collect sufficient data at the monitoring sites. Because branded fish make up only a small portion of the outmigrants, recovery 
necessitates the incidental physical handling of millions of salmonids each year at the collector dams. Thus, the freeze brand/recovery procedures produce an added handling stress to a large portion of the outmigrants within the Columbia River system.

The use of PIT tags instead of brands has the potential to provide statistically and/or biologically comparable results with a 90 to $95 \%$ reduction in the number of fish required for a given study (Prentice et al. 1986). By using PIT tags in studies that deal with juvenile salmonids within the snake and Columbia river systems, the number of fish stressed at marking can be dramatically reduced. Furthermore, stress to the general population of migratory fish would also be reduced since PIT tag monitoring is passive (i.e., requires no handling of fish for recovery of identification information).

The objective of the present study was to compare the difference in behavior, survival, and detection ratio of two species of PIT-tagged and branded fish interrogated or observed at the juvenile collection facilities at Lower Granite and McNary dams. The study was a cooperative effort between the Fish Passage Center and the NMFS. Spring chinook salmon and steelhead from the Dworshak National Fish Hatchery (NFH) near Orofino, Idaho, were evaluated (Fig. 11). All branded fish were part of releases coordinated for water budget management (Annon. 1987).

\section{Methods and Materials}

Spring chinook salmon were freeze-branded, coded-wire-tagged, and adiposeclipped by the Idaho Department of Fish and Game (IDFG) using methods described by Park et al. (1974) between 18 and 22 November 1985. In early February, a total of 41,584 branded spring chinook salmon. ranging in fork length from 99 to $190 \mathrm{~mm}$ (100 fish sample), were placed into two raceways. Between 19 and 
21 February 1986, a group of 2,500 spring chinook salmon, ranging in fork length from 80 to $189 \mathrm{~mm}$, were randomly selected from an adjacent raceway and PIT tagged using methods described in Appendix A. Individual PIT tag code and fork length $( \pm 3 \mathrm{~mm})$ were recorded for each fish, and $10 \%$ of the fish were weighed (LO. $5 \mathrm{~g})$.

In one of the two raceways containing branded fish, 2,300 PIT-tagged fish were added. An additional 200 fish were held for 22 days in a 2-m diameter circular tank for tag retention and survival documentation. Daily mortalities from the raceway and the tank were collected by the hatchery staff and stored in $70 \%$ ethanol for later examination. Mortalities were subtracted from the number marked to obtain the number released. Fish from the 200-fish observation group were monitored for tag loss and rejected tags, and the remaining tagged fish were added to the tagged population in the raceway 2 days prior to release. On 25 March 1986, 100 fish were sampled by IDFG personnel for brand condition and fork length.

The release of spring chinook salmon took place on 2 April 1986 between 2000 and 2200 h. Four 101-mm twin loop detectors were installed in the exit of the raceway, and the entire raceway population passed (crowded) through the detector system (Fig. 18). The PIT code, exit time, and release date were automatically recorded onto a computer file and printer. The following day, the entire raceway was visually and electronically examined for PIT tags that might have been rejected.

Steelhead were marked (by branding and PIT tagging) between 2 and 3 April 1985. Fish for the two treatment groups were randomly obtained from a hatchery pond. The freeze-brand group, marked by IDFG, totaled 35.372 and received no other marks. The PIT-tagged group totaled 2,466 fish. Fish from both groups were immediately returned to the pond after marking and tagging. However, a 


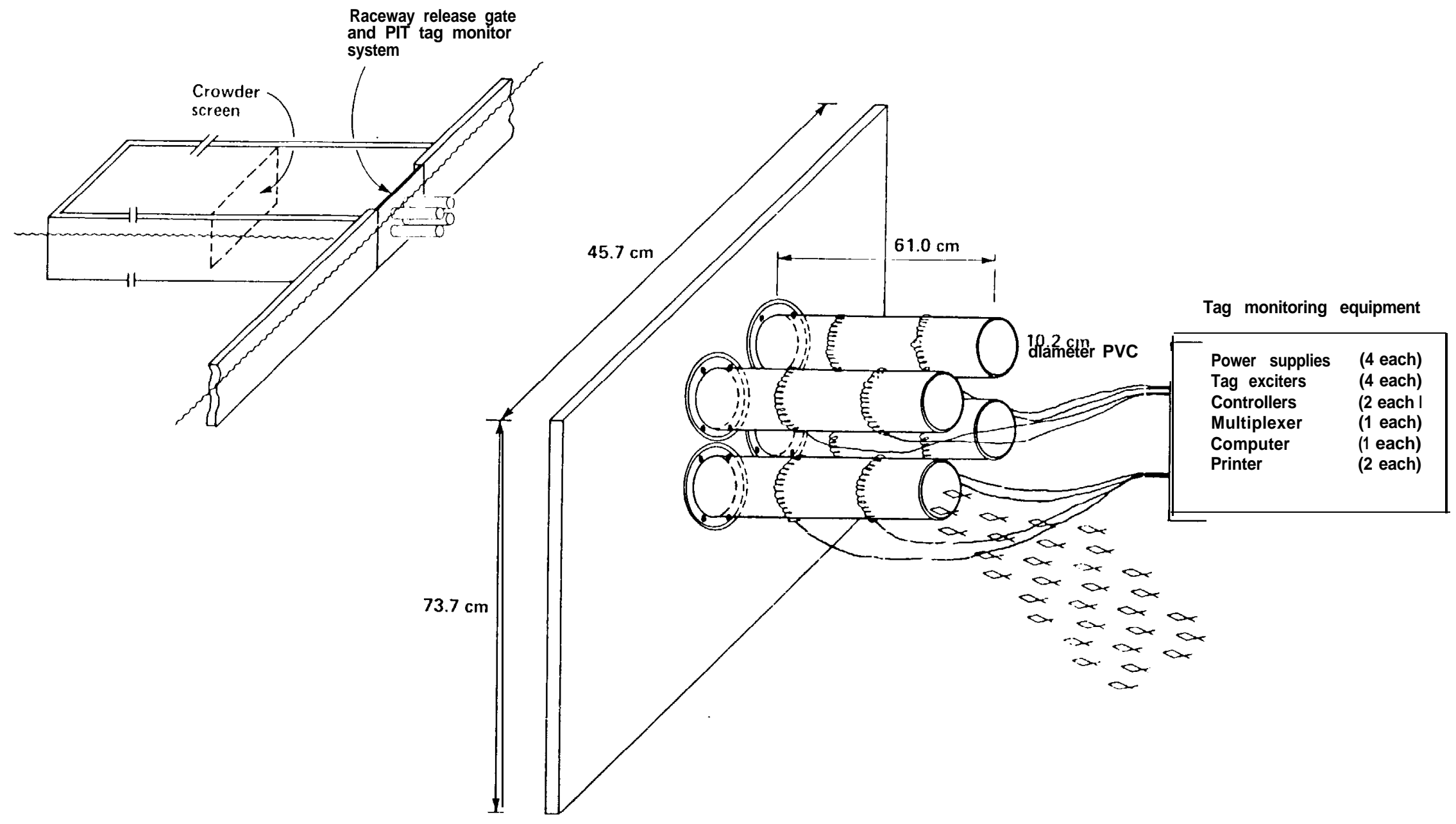

Figure 18.--Hatchcry PIT tag monitor used for release of salmon and steelhead at Dworshak NFH, 1986. 
200-fish sub-sample of PIT-tagged fish was held separately for documentation of tag retention and fish survival. The remaining tagged fish from this (observation) group were added to the population in the pond on the day prior to release.

Daily mortalities from the pond and tank were collected by hatchery staff and stored in 70\% ethanol for later examination. All known mortalities and rejected tags were subtracted from the final release number. Brand condition was evaluated by IDFG personnel 1 week prior to release.

Steelhead were released on 7 May 1986. All fish in the pond were crowded through four 101-mm twin loop detectors between 1000 and 1200 h (Fig. 18). Following the release, the pond was visually and electronically examined for PIT tags that might have been rejected.

Branded fish were monitored by NMFS personnel as part of the smolt Monitoring Program at Lower Granite and McNary dams (Annon. 1987). Brand information was collected (subsampled) on a daily basis and expanded according to the sample rate at each location. Sample rates averaged $10 \%$ for spring chinook salmon and 7\% for steelhead at Lower Granite Dam and 10\% for both species at McNary Dam.

PIT-tagged fish were passively monitored at Lower Granite and McNary dams by the PIT tag detection systems. Of the fish passing through the collection facilities, $100 \%$ were interrogated, and the tag code and detection time $( \pm 1 \mathrm{sec})$ were recorded for each tagged fish. The study was terminated at each monitor site when the last fish from the branded or PIT-tagged group was observed.

Recovery data were evaluated using the $\mathrm{G}^{2}$-statistic described by Sokal and Rohlf (1981). Significance was set at $P<0.05$ for relative differences between treatments. Travel time data for PIT-tagged fish were given to the Fish Passage 
Center to compare PIT tag timing with brands. A separate evaluation of these data can be found in Annon. (1987).

Results and Discussion

Spring Chineok Salmon.--Noapparent difference in pre-release mortality was observed between PIT-tagged (2.0\%) and branded fish (2.2\%) (Table 14). This is consistent with previous studies indicating that the PIT tag does not compromise survival compared to other traditional marking methods (Prentice et al. 1986).

PIT tag codes were monitored as spring chinook salmon were released from the raceway, and problems with release monitor software were observed. When large numbers of PIT-tagged fish passed through the detectors in a short time, the computer buffers became overloaded and the system would temporarily shut off. Consequently, approximately $50 \%$ of the fish were not detected at release and no determination of release number was made using this method. Release numbers were estimated, however, from the known survival 'of the population.

Brand quality (readability) and PIT tag retention were compared. Brand condition of the spring chinook salmon was estimated by IDFG at $97 \%$ readable, $1 \%$ non-readable, 1\% no brand, and 1\% ulcered or burned. In addition, 5\% of the **good" brands were observed to be in the wrong position. Adjustments for brand readability are normally not made for smolt monitoring. Therefore, no adjustments were made to the final release number for this test. PIT tag retention was estimated to be at least $98 \%$ over the 41- to 43-d holding period (four tags were rejected from the 200 fish observation sample and 22 tags were recovered from the raceway). Known rejected tags were removed from the population at release.

Significant differences $(\mathrm{P}<0.05, \mathrm{df}=1)$ between percent data recovery for PIT-tagged and branded fish were observed at the juvenile collection facilities 
Table 14. --Summary of Duorshak NFH rel ease studi es - 1986.

\begin{tabular}{|c|c|c|c|c|c|c|c|c|c|c|}
\hline \multirow[b]{3}{*}{ Speci es } & \multirow[b]{3}{*}{ Treat nent } & \multirow{3}{*}{$\begin{array}{c}\text { Total } \\
\text { fi sh } \\
\text { handl ed }\end{array}$} & \multirow{3}{*}{$\begin{array}{c}\text { Total } \\
\text { fi sh } \\
\text { rel eased }\end{array}$} & \multirow{3}{*}{$\begin{array}{c}\text { Pre-rel ease } \\
\text { nortal i ty } \\
\%\end{array}$} & \multicolumn{6}{|c|}{ Nunber of fish by nonit or location ${ }^{a}$} \\
\hline & & & & & Lower & Granite $\mathrm{Da}$ & am & & Nary Dam & \\
\hline & & & & & Observed & Expanded & $\%$ & Observed & Expanded & $\%$ \\
\hline $\begin{array}{l}\text { Spri ng } \\
\text { chi nook }\end{array}$ & Brand & 41.504 & 40.675 & 2.2 & 474 & 4.659 & 11.5 & 362 & 3,402 & 8.9 \\
\hline $\begin{array}{l}\text { Sprl ng } \\
\text { chi nook }\end{array}$ & PIT tag & 2,500 & 2.450 & 2.0 & 464 & ---- & 18.9 & 264 & ---- & 10.8 \\
\hline Steel head & Brand & 35,372 & 35.025 & 1.0 & 571 & 7.061 & 20.2 & 39 & 389 & 1.1 \\
\hline Steel head & PIT tag & 2,466 & 2.424 & 1.7 & 928 & ---- & 38.1 & 45 & $\cdots$ & 1.8 \\
\hline
\end{tabular}

axpanded number derived from daily (brand recovery) sampling. 
at Lower Granite $\left(\mathrm{G}^{2}=108\right)$ and McNary dams $\left(\mathrm{G}^{2}=16\right)(18.9$ vs $11.5 \%$, and 10.8 vs 8.9\%, respectively), with PIT tag data being recovered at a higher rate (Fig. 19). At Lower Granite Dam, 464 PIT tags were detected and 4,659 brands observed whereas at McNary Dam, 264 PIT tags and 3,402 brands were documented. The brand data are an expansion of the sub-samples adjusted by daily sampling rates whereas PIT tag detection represents interrogation of $100 \%$ of the fish exiting the wet separator (Table 14). A partial explanation for the difference between brand and PIT tag recovery may be that PIT tag detectors electronically interrogate $100 \%$ of the fish passing through the wet separator at a collection facility whereas brand recovery can be influenced by unreadable brands, human error in brand identification, and errors in data recording. However, fish behavior and in-river mortality may also be contributing factors in the lower rate of brand recovery.

The handling ratio between PIT-tagged and branded fish at both dams during the collection period was 1:315. This ratio includes the number fish handled during marking as well as the number handled at the dams during sampling. These data indicate that significantly fewer fish were stressed by handling using the PIT tag method than by the traditional freeze branding methods.

The first and last Dworshak NFH freeze-branded spring chinook salmon were observed on 8 April and 1 June 1986 at Lower Granite Dam and 22 April and 28 May 1986 at McNary Dam, respectively. PIT-tagged fish were detected between 8 April and 1 June 1986 at Lower Granite Dam and 22 April and 28 May 1986 at McNary Dam. The median travel time (days) to Lower Granite Dam and McNary Dam were similar for both the PIT-tagged and branded spring chinook salmon groups $(20$ and $19 \mathrm{~d}$, and 33 and $39 \mathrm{~d}$, respectively). This indicates that the PIT tag does not influence the migration of spring chinook salmon compared to traditional marking methods. 


\section{$\%$ RECAPTURE}

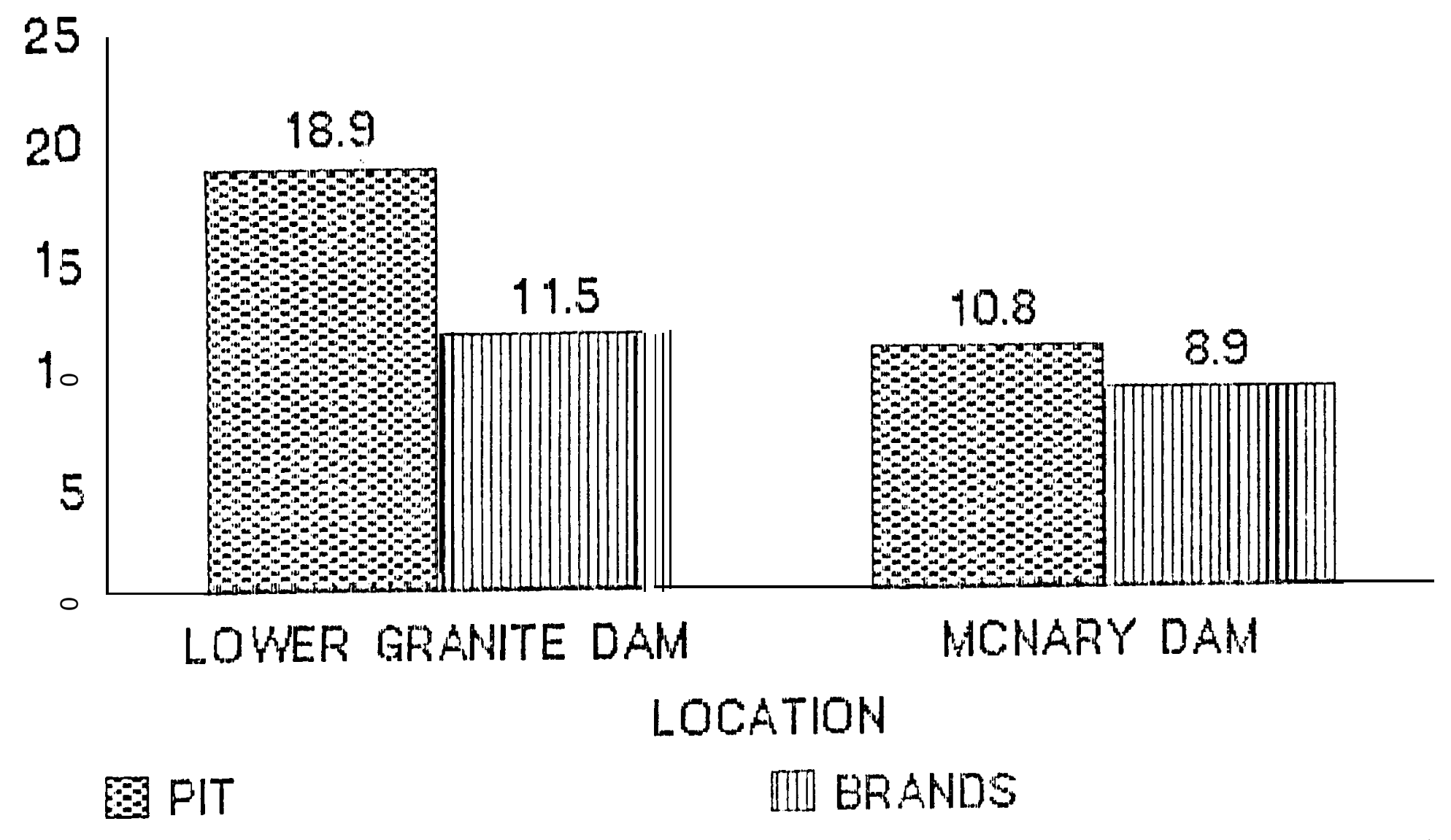

Figure 19.--Percent recapture of PIT-tagged and branded spring chinook salmon released from Dworshak NFH, 1986. 
Steelhead.--No signif lcant difference was observed in pre-release mortality between the PIT-tagged (1.7\%) and freeze-branded fish (1.0\%) (Table 14). These results are similar to those obtained with spring chinook salmon, further supporting our conclusion that, when properly applied, the PIT tag does not compromise the survival of the fish.

PIT tag retention was evaluated prior to release of these groups of steelhead. PIT tag retention in the 200 fish observation group was $93.0 \%$ which was exceptionally low compared to previous studies (Prentice et al. 1984, 1985, and 1986) and appeared to be due to improper tagging technique. An antibiotic/ petroleum jelly compound was used to help hold the tag within the bore of the tagging needle. The adhesiveness of the compound caused the tag to remain on the tip of the needle and, therefore, not to be inserted properly. The tagging technique has been modified to avoid the problem by eliminating the compound and/or replacing it with ethanol.

Data collected during tag monitoring at release accounted for all but $7.5 \%$ of the PIT-tagged fish in the main population. However, for consistency with the spring chinook salmon test, release monitor data were not used for population recovery estimates. Therefore, all PIT tag recovery data are compared to the actual number of fish tagged minus mortalities and known rejected tags.

Brand quality observations were made by IDFG prior to release, these estimates indicated that $2 \%$ of the steelhead had unreadable brands, $6 \%$ were marked in the wrong location, and 42\% had burned or ulcered brands. Of the burned or ulcerated brands, all were determined to be "readable but obscured" at the time of the sample. Adjustments for brand readability are normally not made for smolt monitoring. Therefore, no adjustments were made to the final release number for this test. 
Significant $(P<0.05, \mathrm{df}=1)$ differences between PIT tag detection and brand observations were observed at Lower Granite $\left(G^{2}=388\right)$ and McNary dams $\left(G^{2}=9\right)$ (38.1 Vs $20.2 \%$, and 1.8 vs $1.1 \%$, respectively) (Fig. 20). The 928 PIT tags detected at Lower Granite Dam and the 45 detected at McNary Dam represent interrogation of $100 \%$ of the fish exiting the wet separators. The 7,061 oberservations for branded fish at Lower Granite Dam and the 389 at McNary Dam were arrived at by expanding sub-sample data by the daily sample rate (Table 14). A partial explanation for the difference between brand and PIT tag recovery rates for these groups of steelhead may be that PIT tag detectors electronically interrogate $100 \%$ of the fish passing through the wet separator at a collection facility whereas brand recovery can be influenced by unreadable brands, human error in brand identification, and errors in data recording. In addition, it is likely that a large number of the burned or ulcered branded fish may have died or the brands became unreadable between time of release and recapture.

Overall handling ratio between PIT-tagged andbranded fish was $1: 161$, this ratio includes the number fish handled during marking as well as the number handled at the dams during sampling. These data indicate that significantly fewer steelhead were stressed by handling using the PIT tag method than by the traditional freeze branding methods.

Dworshak NFH freeze branded steelhead were observed between 9 May and 14 June at Lower Granite Dam and between 16 May and 8 June 1986 at McNary Dam. PIT tags were detected between 9 May and 14 June 1986 at Lower Granite Dam and between 16 May and 8 June 1986 at McNary Dam. The median travel times (days) to Lower Granite Dam and McNary Dam were similar for both the PIT-tagged and branded steelhead groups and differed by only 1 d at both locations $(9 \mathrm{~d}$ and $10 \mathrm{~d}$, and $20 \mathrm{~d}$ and $19 \mathrm{~d}$, respectively). This indicates that the PIT tag does 


\section{$\%$ RECAPTURE}

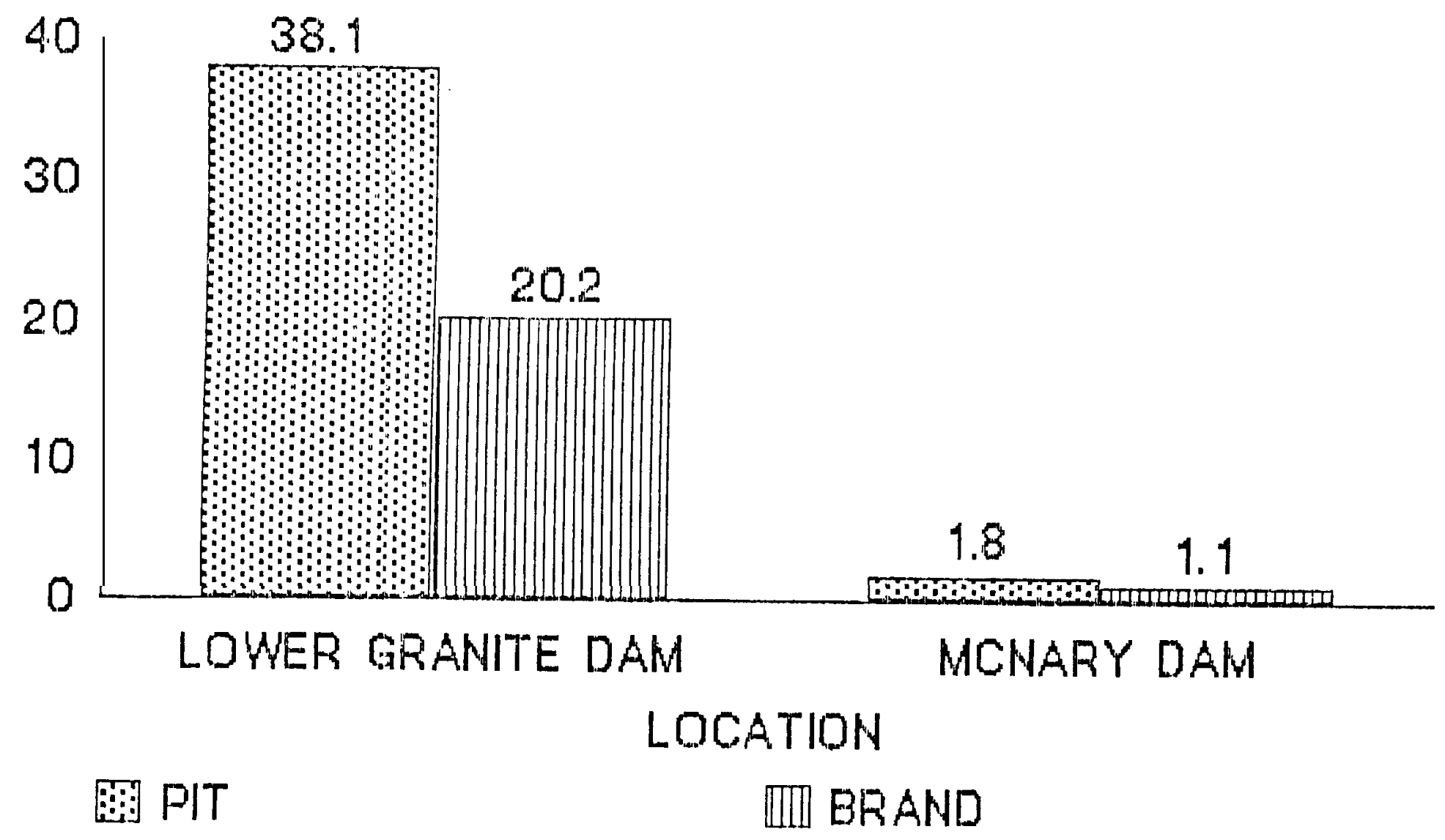

Figure 20.--Percent recapture of PIT-tagged and branded steelhead released from Dworshak NFH, 1986. 
not influence the apparent migration rate of steelhead as compared to traditional marking methods.

McNary Reservior Releases

Introduction

In 1985, tests were conducted comparing the collection ratio of freezebranded fall chinook salmon to PIT-tagged fall chinook salmon at the McNary Dam juvenile fish collection facility. No significant difference in the collection efficiency between the two groups was indicated whereas a significant difference between the handling ratio was observed. Data analysis also indicated that PIT tag recovery data were more statistically reliable than brand data (Prentice et al. 1986).

In 1986, the PIT tag monitor system was upgraded and new glass-encapsulated PIT tags were developed. Therefore, the reservoir release studies were repeated in the 1986 field season to evaluate the new system.

Methods and Materials

Steelhead and yearling and underyearling outmigrating chinook salmon were scheduled for use in the study. Steelhead were to be tested on 2 June 1986; however, the test was terminated the same day due to low numbers of steelhead in the collected sample. To collect enough steelhead would have required excessive numbers of miscellaneous species to have been handled. Outmigrating yearling chinook salmon were tested from 13 to 27 May 1986. Testing of underyearling chinook salmon was conducted from 10 July to 8 August 1986.

All fish were randomly sampled from the McNary Dam juvenile collection facility. However, no weak, highly descaled or previously marked fish were used. A total of 5,500 yearling and 5,500 underyearling fall chinook salmon were used in the two tests (Table 15). Marking and PIT tagging were conducted 
Table 15.--Recovery of branded and PIY-tagged yearling and underyearling chi nook sal non rel eased into MeNary Reservoi $r$, 1986.

\begin{tabular}{|c|c|c|c|c|c|c|c|c|}
\hline Year cl ass & Treatment $^{a}$ & $\begin{array}{l}\text { Total fi sh } \\
\text { tagged and } \\
\text { branded }\end{array}$ & $\begin{array}{c}\text { Pre- } \\
\text { rel ease } \\
\text { nortal i ty } \\
\quad 1 \%\end{array}$ & $\begin{array}{l}\text { Total fish } \\
\text { handled }\end{array}$ & $\begin{array}{c}\text { Actual } \\
\text { number of } \\
\text { fi sh } \\
\text { observed }\end{array}$ & $\begin{array}{c}\text { Expanded } \\
\text { nunber of } \\
\text { fi sh } \\
\text { observed }\end{array}$ & $\begin{array}{l}\text { Percent } \\
\text { observed }\end{array}$ & $\begin{array}{c}\text { Standard } \\
\text { devi ati on } \\
(\%)\end{array}$ \\
\hline $\begin{array}{l}\text { Under- } \\
\text { yearl i ing }\end{array}$ & Brand & 5,000 & 3.8 & 206. 849 & 95 & $1.371^{\mathrm{c}}$ & 27.4 & 4 \\
\hline $\begin{array}{l}\text { Under- } \\
\text { yearl i ng }\end{array}$ & PIT tag & 500 & 3.6 & 500 & 142 & $142^{d}$ & 28.4 & 1 \\
\hline Yearl i ng & Brand & 5,000 & 1.5 & 165. 190 & 194 & $2.101^{\mathrm{e}}$ & 38.9 & 10 \\
\hline Yearl ing & PIT tag & 500 & 1.0 & 500 & 318 & $318^{d}$ & 63.6 & 2 \\
\hline
\end{tabular}

a Al data are for conbi ned replicates.

b Incl udes al I species handl ed in marking and sampl ing during the experi mental peri od.

c The expanded val ue is based upon adjusting the actual observed number of fish in the subsample by 14. 3 to adj ust for the subsanple rate during that coll ection period.

d $\mathrm{Nb}$ expansi on factor is requi red si nce the number of $\mathrm{fish}$ observed represents $100 \%$ of the PIT tagged fish passing through the collection facility.

e The expanded val ue is based upon adjusting the actual observed number of fish in the subsanple by 10.0 to adj ust for the $10 \%$ subsample during that collection period. 
over a 5-d period for both species, with 1,100 fish handled each day. Of the 1,100 fish used daily, 100 fish were randomly subsampled and injected with PIT tags using the method described in Appendix A. All PIT-tagged fish were measured to the nearest $+3 \mathrm{~mm}$ (fork length), and a $10 \%$ subsample was weighed to the nearest $0.5 \mathrm{~g}$. The remaining 1,000 fish were marked with a freeze brand (Park and Ebel 1974) and the upper caudal fin clippedI' but not weighed or measured. The yearling chinook salmon ranged in length from 102 to $298 \mathrm{~mm}$ whereas the underyearling fish ranged in length from 72 to $151 \mathrm{~mm}$. All fish were transferred via flowing water to a 1,800-liter transport tank located on a truck. Brands were changed daily for each replicate, and each PIT-tagged fish had an individual code. Both PIT-tagged and branded fish were held together in the transport tank for $24 \mathrm{~h}$ with flow through water prior to being transported to the Walla Walla Yacht Harbor at Port Kelly, Washington, $35 \mathrm{~km}$ upstream from McNary Dam. The fish were transferred from the truck via gravity flow through a hose to a barge carrying a transport tank receiving a continuous supply of river water. The fish were then barged to the main river channel and released. Prior to release, all dead fish were collected for tag and mark identification.

PIT tag detection was performed by three automatic monitoring systems located at the McNary Dam juvenile salmonid collection facility. The tag monitor systems required no handling of fish and automatically stored tag codes, detection time, and date on a computer file and printer. The monitor systems were positioned to interrogate $100 \%$ of the fish passing through the juvenile collection facility (Fig. 13).

Branded fish were monitored by NMFS personnel at the juvenile salmon collection and inspection facility at McNary Dam as part of the Smolt Monitoring

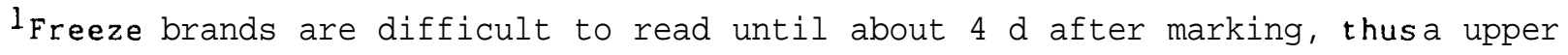
caudal clip is generally used by researchers as a flag whenever brands are expected to be read prior to $4 \mathrm{~d}$. 
Program (Annon. 1987). A subsample of the fish exiting the wet separator was diverted to an inspection room by a timer system which opened the sample gates. The subsampled fish were dipnetted; anesthetized; and inspected for fin clips, descaling, injuries, and brands. The fish were then diverted to a raceway for transport downstream. Subsample rates were targeted at $10 \%$ for yearling and $7 \%$ for underyearling chinook salmon. However on several occasions during both tests, numbers of juveniles being collected exceeded the carrying capacity of the subsampling system, requiring the subsample to be reduced until the numbers collected dropped to safe levels. Therefore, the expansion factor for brand collection was adjusted to the actual daily sample rate.

Comparison between numbers of fish handled with PIT tags and brands was terminated when the last fish from either group was observed (2 June 1986 for yearling chinook and 8 August 1986 for underyearling chinook salmon). Recovery data were used to form contingency tables utilizing the $\mathrm{G}^{2}$-statistic described by Sokal and Rohlf (1981) .

Results and Discussion

A total of 5,500 each of yearling and underyearling chinook salmon were used in the 1986 reservoir release comparative study. The spring outmigration of yearling chinook salmon is primarily composed of spring, summer, and fall races and occurs from April to June. The underyearling outmigration occurs in July and is primarily composed of fall chinook salmon stocks. Results are summarized in Table 15.

Yearling Chinook Salmon.--Asignificant difference $(P<0.01$, df=l) in recovery rate was observed between the brand and PIT tag groups. The total number of PIT-tagged yearling chinook salmon detected exiting the collectionfacility was 318 (63.6\%). This represented interrogation of $100 \%$ of the PIT-tagged fish that 
were guided and passed through the collection facility at McNary Dam. The total number of branded yearling chinook salmon observed (expanded according to daily sampling rates) was estimated to be 2,101 (38.9\%). The number of detected fish from either group should represent the collection efficiency for McNary Dam for outmigrating yearling chinook salmon during the collection period.

Significantly different recovery rates were observed among the five branded replicates $(\mathbf{P}<\mathbf{0 . 0 1}, \mathrm{df}=4)$ whereas no significant difference $(\mathrm{P}<0.01, \mathrm{df}=4)$ existed among replicates of PIT-tagged yearling chinook salmon (Fig. 21). This indicated that the PIT tag provides more precise recovery estimates than brand information for migrating yearling chinook salmon.

During these tests, 165,190 fish were handled for branding and brand sampling to obtain 194 fish in the subsample. For the PIT-tagged groups, however, only 500 fish were handled to obtain data on 318 fish while an estimated 1,632,086 fish were passively monitored. This handling difference equates to a ratio of $330: 1$. In addition, $99 \%$ of the fish sampled for the brand evaluation were not branded and, therefore, were unnecessarily stressed.

The large discrepancy between recovery rates of PIT-tagged versus branded yearling chinook salmon test groups as well as the statistical difference among the brand replicates suggest a potential bias may be associated with the recovery process or readability of brands. Therefore, we recommend further testing addressing the sampling process to identify the source of error.

Underyearling Chinook Salmon.--Nosignificant difference was observed between the recovery of branded and PIT-tagged underyearling chinook salmon. The total number of PIT-tagged underyearling chinook salmon exiting from the collection facility was $142(28.4 \%)$. The estimated number of branded underyearling chinook salmon recovered was $1,371(27.4 \%)$. Both the brand and PIT tag recovery rates 


\section{$\%$ RECAPTURE}

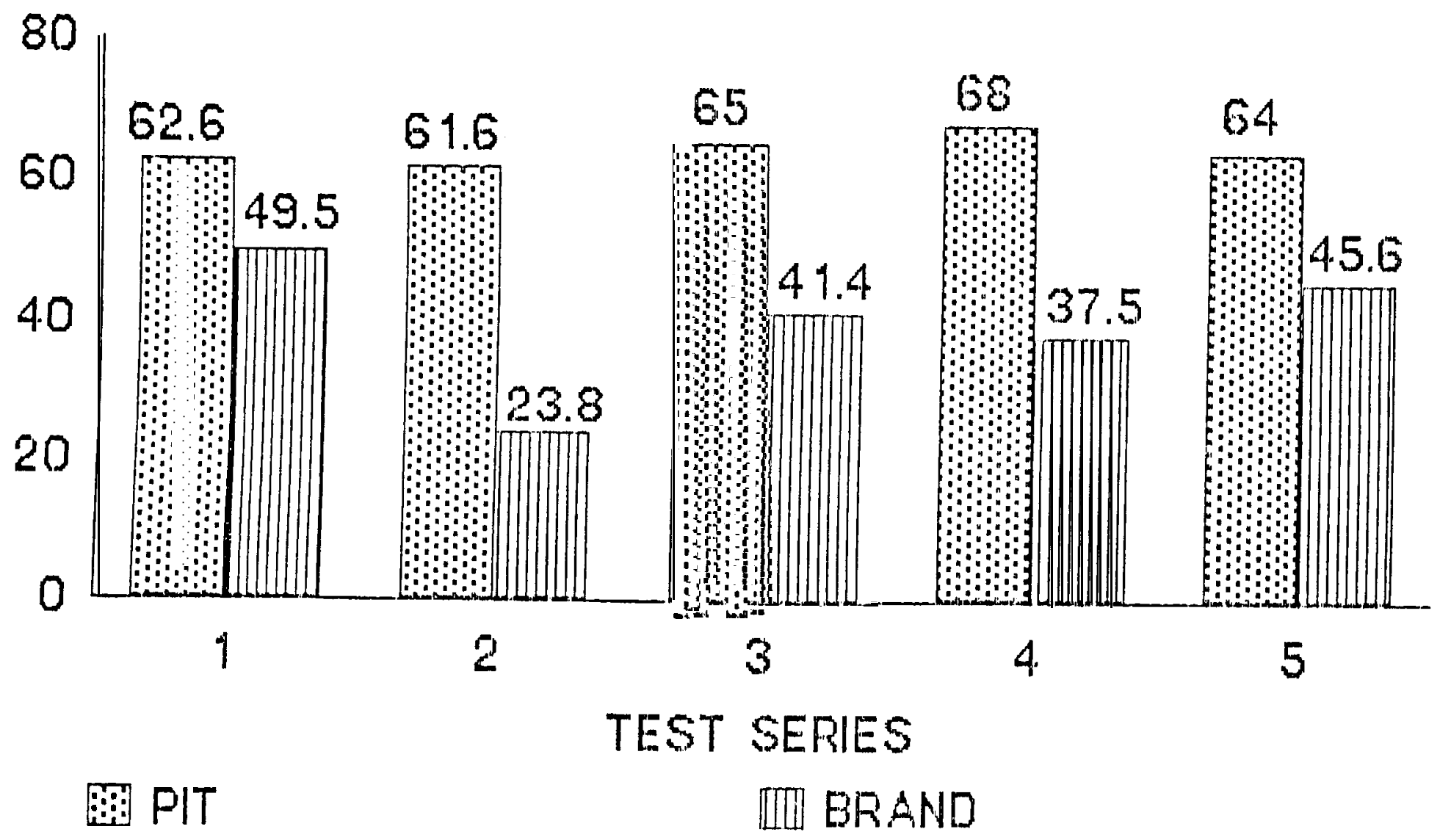

Figure 2 McNary Dam recoveries of five test groups of PIT-tagged and branded yearling chinook salmon released into McNary reservoir, 1986. 
should represent the collection efficiency of the bypass system at McNary Dam during the test period.

A concurrent study to determine the efficiency of submersible traveling screens in guiding fish from turbine intakes to the bypass system was conducted by NMFS (Swan and Norman 1987). They estimated the average guiding efficiency (which also represents collection efficiency because there was no spill during this time period) to be $28.4 \%$, which compares quite well with our findings.

Even though there was no difference between the total percent recovery of branded underyearling chinook salmon, there was a significant difference $(\mathrm{P}<0.01, \mathrm{df}=4)$ among the five replicates in the brand study group. Because no similar significant differences were found among the five PIT tag groups (Fig. 22), the PIT tag data can be considered more statistically reliable. This finding is supported by similar results observed in the 1985 Reservoir study (Prentice et al. 1986).

While testing underyearling chinook salmon, 206,849 fish were handled in the marking and subsample process. Meanwhile, only 500 total underyearling chinook salmon were handled for the PIT tag marking, and an estimated 2,881,006 were passively monitored by the PIT tag system. This equates to a ratio of 414:1 in handling difference between the two methods. Furthermore, of the 206,849 fish handled for brand evaluation, 99\% were unmarked fish and were, therefore, unnecessarily stressed.

$$
\begin{gathered}
\text { Comparison of the PIT tag to Traditional } \\
\text { Tagging and Marking Methods }
\end{gathered}
$$

Introduction

The objective of this work was to compare survival of fish injected with PIT tags to survival of fish tagged and/or marked using traditional methods 


\section{$\%$ RECAPTURE}

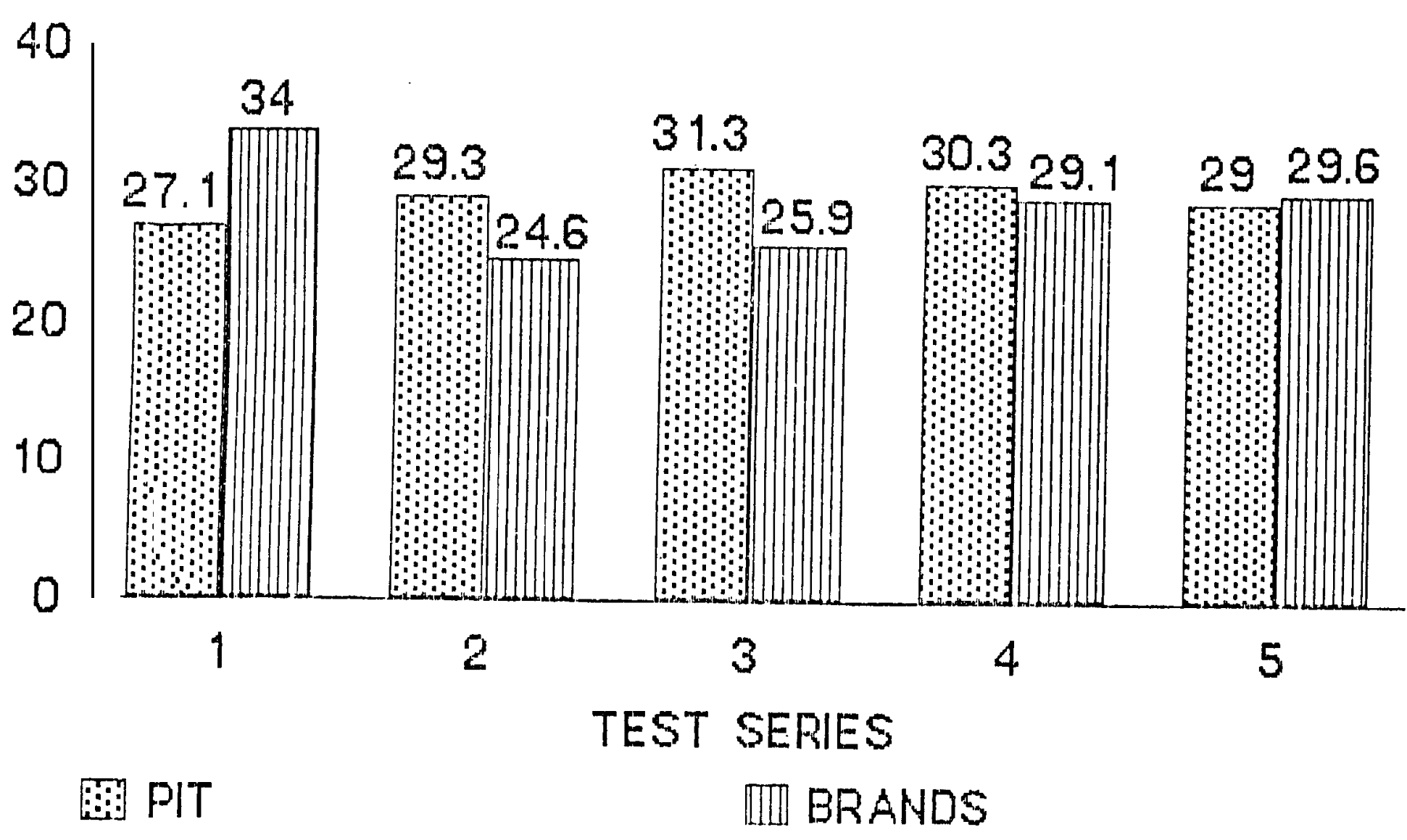

Figure 22. -McNary Dam recoveries of five test groups of PIT-tagged and branded underyearling chinook salmon released into McNary reservoir, 1986. 
[coded wire tags (CWT) and freeze brandsl under conditions that prevail at a dam. These tests were conducted at Lower Granite and McNary dams (Fig. 11) using migrant juvenile salmonids. It is believed that comparisons with in-river migrants represent a severe test of tagging and marking methods.

Methods and Materials

Comparative studies were conducted at Lower Granite Dam from 10 April to 19 May and at McNary Dam from 28 April to 30 July. Outmigrating yearling chinook salmon and steelhead 'were evaluated at Lower Granite Dam whereas yearling and underyearling chinook salmon and steelhead were evaluated at McNary Dam. All fish used in the studies were collected from the juvenile collection facilities at the dams. The size of the fish is shown in Table 16.

The survival of PIT-tagged fish was compared to control fish (handled, but not tagged or marked), CWT, CWT and branded, and branded fish. Traditional tagging and branding methods were used in the study. PIT tagging techniques followed the procedures outlined in Appendix A. All treatments (20 fish each) were combined and held as five replicate groups (100 fish each) since each treatment could be recognized by its identifying tag or mark. The fish were held for up to 15 d in four holding pens suspended within a raceway. A continuous supply of ambient river water flowed through the holding pens. The fish were examined daily for mortality.

Survival information was analyzed for differences using the predictive sample reuse (PSR) techniques for categorical data (Kappenman 1983). The model took into account test type (CWT, PIT, CWT and brand, brand, and control), replicate location, and $14-d$ post-test mortality. 
Table 16.--Size of fish used in comparing PIT-tagged fish to traditionally tagged and marked fish.

\begin{tabular}{|c|c|c|c|c|c|c|c|c|c|}
\hline \multirow[b]{2}{*}{ Location } & \multirow{2}{*}{$\begin{array}{c}\text { Year } \\
\text { class/ } \\
\text { species }\end{array}$} & \multicolumn{4}{|c|}{ Weight $(g)$} & \multicolumn{4}{|c|}{ Length $(\mathrm{mm})$} \\
\hline & & Mean & $\mathrm{SD}$ & Minimum & Maximum & Mean & $\mathrm{SD}$ & Minimum & Maximum \\
\hline $\begin{array}{l}\text { Lower } \\
\text { Granite } \\
\text { Dam }\end{array}$ & $\begin{array}{l}\text { Yearling } \\
\text { chinook } \\
\text { salmon }\end{array}$ & 21.1 & 7.6 & 8.7 & 52.7 & 129 & 14 & 100 & 173 \\
\hline $\begin{array}{l}\text { Lower } \\
\text { Granite } \\
\text { Dam }\end{array}$ & Steelhead & 86.7 & 24.3 & 43.0 & 174.2 & 213 & 27 & 168 & 271 \\
\hline $\begin{array}{l}\text { McNary } \\
\text { Dam }\end{array}$ & $\begin{array}{l}\text { Underyearling } \\
\text { chinook salmon }\end{array}$ & 13.6 & 6.5 & 3.1 & 56.9 & 104 & 11 & 85 & 140 \\
\hline $\begin{array}{l}\text { McNary } \\
\text { Dam }\end{array}$ & $\begin{array}{l}\text { Yearling } \\
\text { chinook } \\
\text { salmon }\end{array}$ & 20.6 & 7.0 & 7.8 & 45.9 & 129 & 14 & 94 & 167 \\
\hline $\begin{array}{l}\text { McNary } \\
\text { Dam }\end{array}$ & Steelhead & 66.2 & 20.6 & 21.1 & 115.7 & 203 & 22 & 145 & 247 \\
\hline
\end{tabular}


Results and Discussion

Analysis of the data (Table 17) indicated that all but one test group (McNary Dam underyearling chinook salmon) best fit the model stating: no association exists between replicate location and mortality, tagging and/or marking method and mortality, or tagging and/or marking method and replicate location. The McNary Dam underyearling chinook salmon group best fit the model stating: there was no association between tagging and/or marking method and mortality, or replicate location and tagging and/or marking method, but there was an association between replicate location and mortality. However, all tests indicated that the PIT tag itself does not adversely influence survival.

No explanation can be offered for the association between replicate location and mortality for the McNary Dam underyearling chinook salmon test, since the replicates were randomly distributed. In general, the results (Table 17) obtained using underyearling chinook salmon at McNary Dam were similar to that obtained in 1985 by Prentice et al. (1986). The lower mortality for each treatment group in the 1985 study is attributed to the different environmental conditions and the condition of the fish at the time of testing.

The daily mortality was similar between treatment groups within a test at a specific location (Figs. 23, 24, 25, 26, and 27). The fish at Lower Granite Dam showed higher overall survival than those at McNary Dam. The mortality at Lower Granite Dam occurred primarily during the last days of holding. This mortality pattern is in contrast to that at McNary Dam where a general increase in mortality began on about the third day of holding in all treatment groups. We believe the condition of the fish at the time of tagging and marking was the primary reason for the difference in mortality patterns observed between the two test locat ions. The fish used in the tests conducted at Lower Granite Dam appeared in better overall condition than those used at McNary Dam. 
Table 17.--Summary of survival data (five replicates combined) comparing PIT-tagged fish and traditionally marked and or tagged fish after 14 days of holding.

\begin{tabular}{|c|c|c|c|c|c|c|}
\hline \multirow[b]{2}{*}{ Location } & \multirow{2}{*}{$\begin{array}{l}\text { Year } \\
\text { class/ } \\
\text { species }\end{array}$} & \multirow[b]{2}{*}{ Control } & \multicolumn{2}{|c|}{ Survival } & $(\%)^{a}$ & \multirow[b]{2}{*}{$\begin{array}{c}\text { CWT+ } \\
\text { branded }\end{array}$} \\
\hline & & & $\mathrm{PIT}$ & Branded & CWT & \\
\hline $\begin{array}{l}\text { Lower } \\
\text { Granite } \\
\text { Dam }\end{array}$ & $\begin{array}{l}\text { Yearling } \\
\text { chinook } \\
\text { salmon }\end{array}$ & 95 & 98 & 96 & 97 & 99 \\
\hline $\begin{array}{l}\text { Lower } \\
\text { Granite } \\
\text { Dam }\end{array}$ & Steelhead & 100 & 99 & 100 & 99 & 97 \\
\hline $\begin{array}{l}\text { McNary } \\
\text { Dam }\end{array}$ & $\begin{array}{l}\text { Yearling } \\
\text { chinook } \\
\text { salmon }\end{array}$ & 86 & 83 & 86 & 80 & 89 \\
\hline $\begin{array}{l}\text { McNary } \\
\text { Dam }\end{array}$ & $\begin{array}{l}\text { Underyearling } \\
\text { chinook } \\
\text { salmon }\end{array}$ & 64 & 65 & 59 & 68 & 66 \\
\hline $\begin{array}{l}\text { McNaryb } \\
\text { Dam }\end{array}$ & $\begin{array}{l}\text { Underyearling } \\
\text { chinook } \\
\text { salmon }\end{array}$ & 96 & 87 & 94 & 92 & 93 \\
\hline $\begin{array}{l}\text { McNary } \\
\text { Dam }\end{array}$ & Steelhead & 89 & 87 & 93 & 91 & 91 \\
\hline
\end{tabular}

a PIT indicates PIT-tagged fish, Brand indicates freeze-branded fish, CWT indicates coded-wire-tagged fish, CWT+brand indicates coded-wire-tagged and freeze-branded fish, control indicates fish that were handled but not marked.

b Test conducted in 1985 (Prentice et al. 1986). 


\section{CUMULATIVE MORTALITY (\%)}

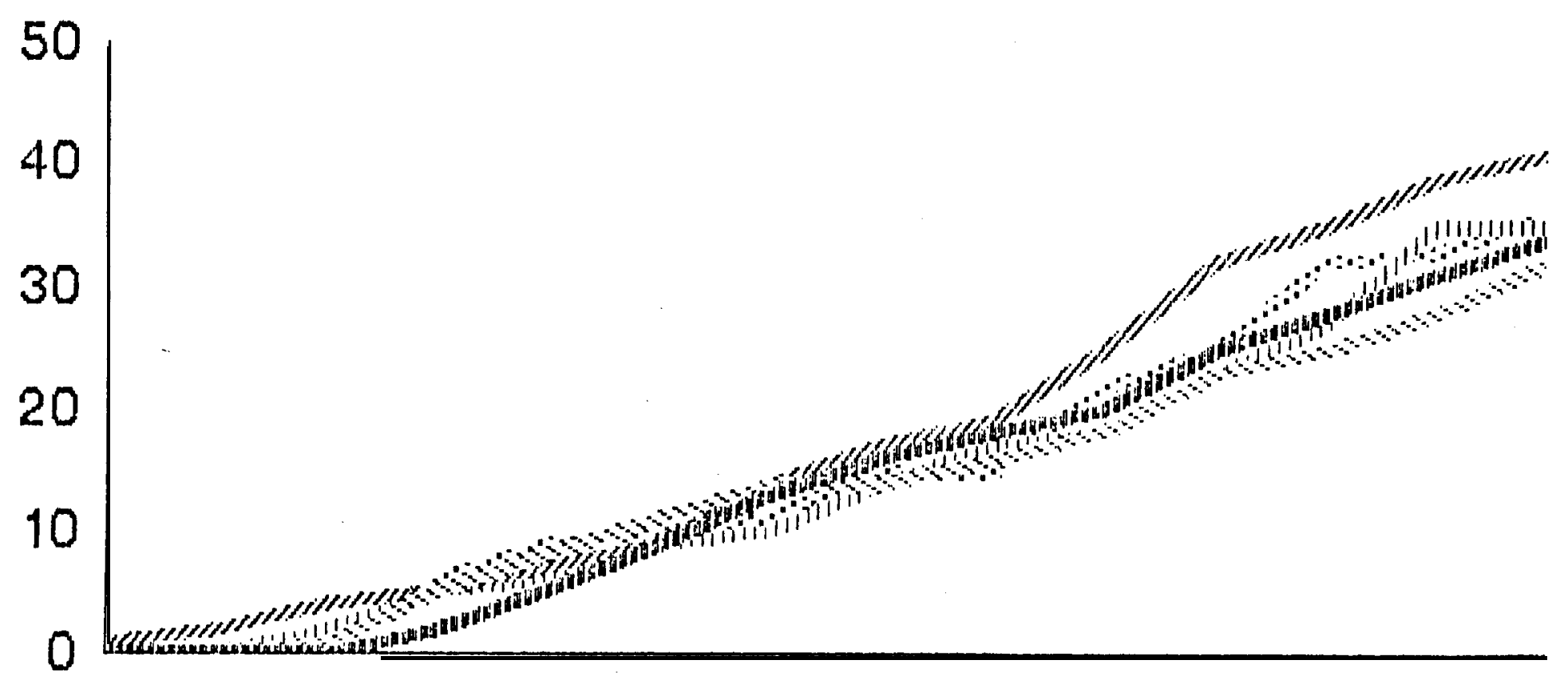

\section{B CONTROL \\ 血 PIT \\ Z BRAND \\ S CWT \\ OWT CWR +BRAND}

Figure 23.--Comparison of 14-d cumulative mortality for underyearling chinook salmon comparative tests conducted at McNary Dam, 1986. 


\section{CUMULATIVE MORTALITY \%}

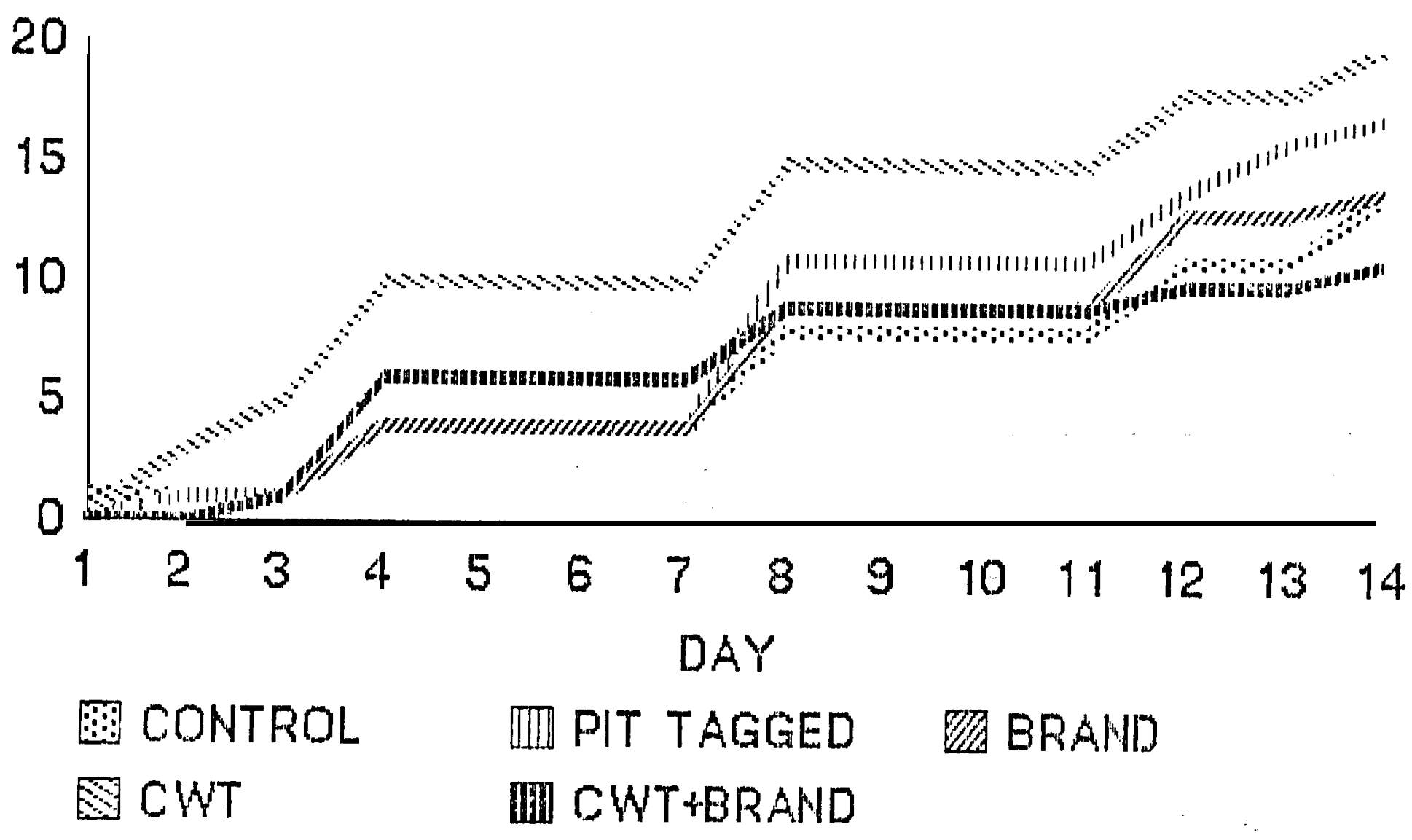

Figure 24.--Comparison of 14-d cumulative mortality for yearling chinook salmon arative
tests conducted at McNary Dam, 1986 . 


\section{CUMULATIVE MORTALITY (\%)}
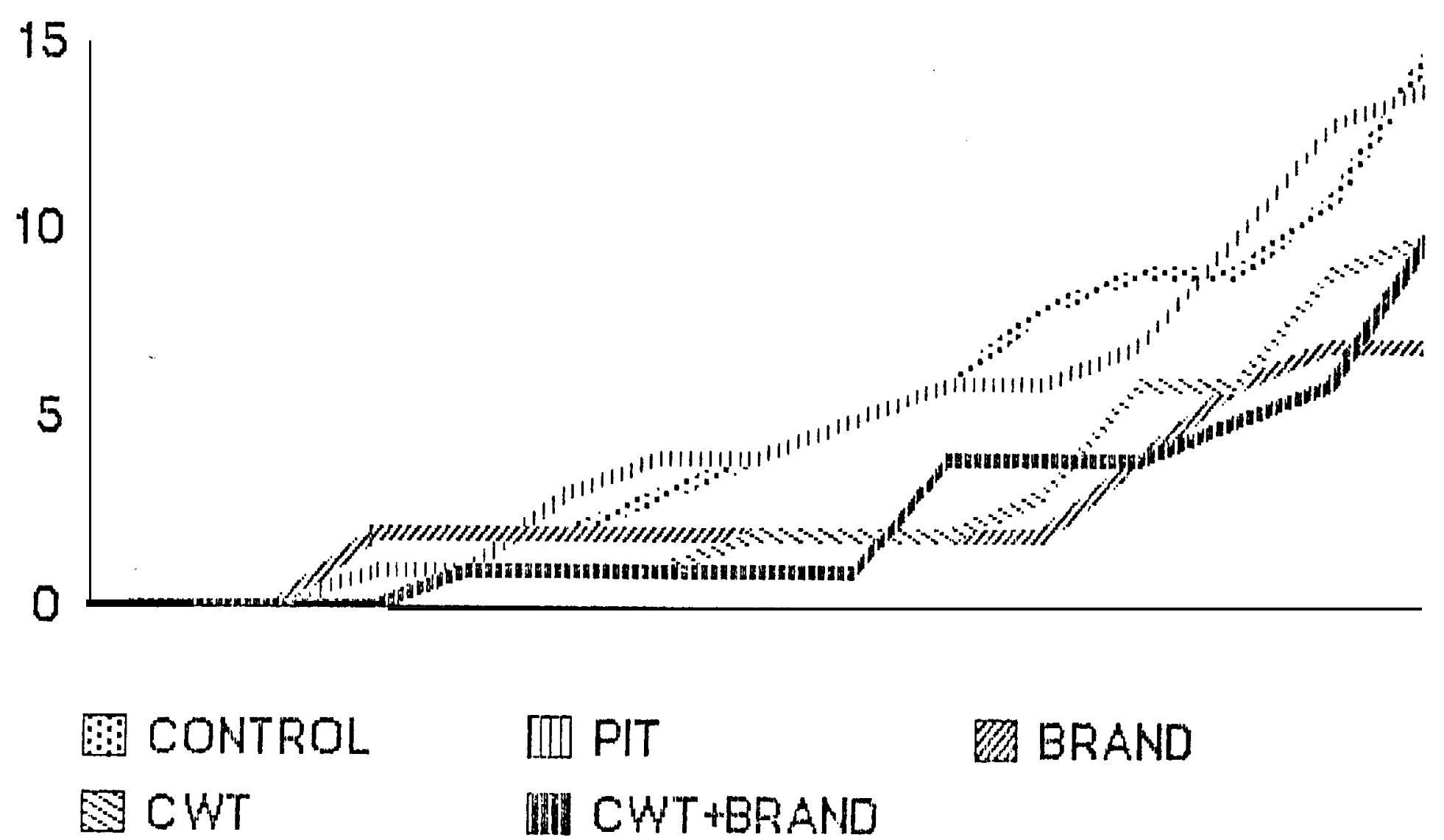

Figure 25.--Comparison of 14-d cumulative mortality for steelhead comparative tests conducted at McNary Dam, 1986. 


\section{CUMULATIVE MORTALITY (\%)}

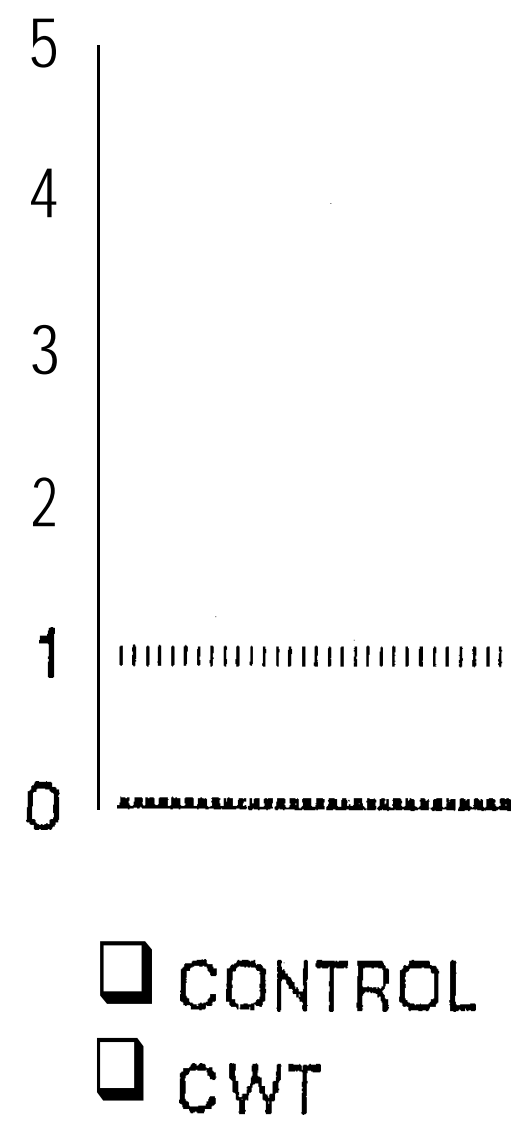

\section{政 PIT \\ 咩 CWT+BR.AND}

BRAND

Figure 26.--Comparison of 14-d cumulative mortality for yearling chinook salmon comparative tests conducted at Lower Granite Dam, 1986. 


\section{CUMULATIVE MORTALITY (\%)}

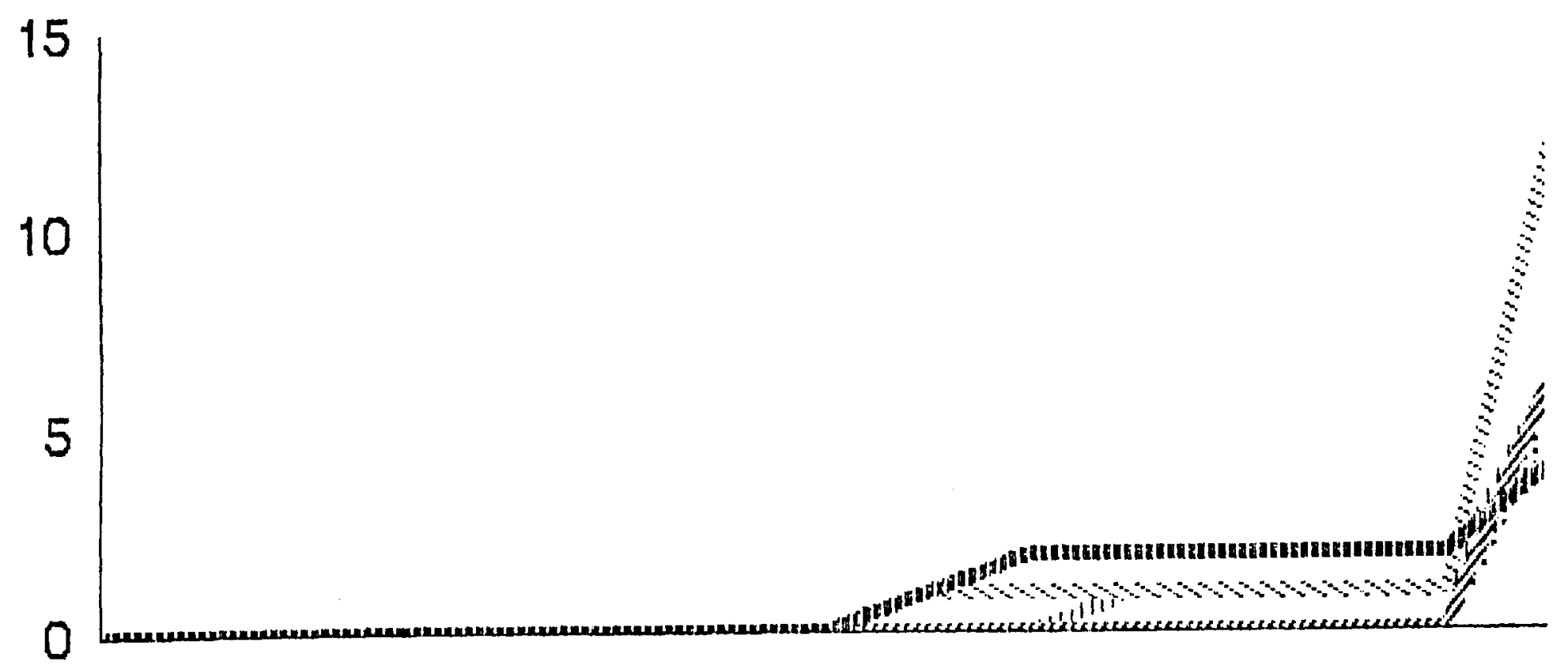

$\begin{array}{ll}\text { CONTROL } & \text { 而 PIT } \\ \text { CWT } & \text { DRAND }\end{array}$

Figure 27.--Comparison of 14-d cunulative mortality for steelhead comparative tests conducted at Lower Granite Dam, 1986. 
Most dead fish were necropsied. The fish examined showed descaling and fungus infection in various locations but mostly in the caudal area. No signs of disease or fungus in the vicinity of the wound made by the PIT tag injection needle were seen on live or dead fish. All PIT-tagged fish showed complete closure of the injection wound. Nitrogen supersaturated water caused the mortality of spring chinook salmon at Lower Granite Dam on the 14th day of holding. On the 15th day of observation, nearly all fish were dead from the water problem.

The holding of migrating juvenile salmon and steelhead in river water at a collection dam for an extended period of time is a stressful situation. It is believed, however, since no adverse effect of the PIT tag on survival was seen under these conditions, that under more favorable conditions of capture, tagging, and holding, the PIT tag would not create any problems to migrant juvenile salmon or steelhead.

\section{Conclusions and Recommendations}

1. For most mark, release, and recapture studies with migrant salmonids the use of the PIT tag can increase both quality and quantity of data collected.

2. The PIT tag system will give more precise data than the present freeze brand monitoring system.

3. The PIT tag system provides the same or higher recovery rates than traditional marking methods and requires over $90 \%$ less fish for many types of studies.

4. With PIT-tagged fish, all recovery information is passively obtained: therefore, the PIT tag markedly reduces the overall handling stress inherent in mark/recapture experiments. 
5. Juvenile migrant salmon or steelhead tagged with the PIT tag are no more likely to suffer mortality than traditionally tagged and marked fish.

6. PIT tag monitors installed at dams can be expected to provide tag detection efficiencies of over 95\%.

7. The PIT tag can be read efficiently and accurately in juvenile salmon and steelhead that pass volitionally from a wet-separator and through a PIT tag detection system.

8. The glass-encapsulated version of the PIT tag has the potential to be a reliable tool for fisheries research.

9. We recommend against the use of a highly viscous compound (e.g., petroleum jelly) for holding the tag within the bore of the tagging needle because of potential tag retention problems.

10. We recommend that a minimum of two independent double loop assemblies be used for passive PIT tag detection. In addition, one controller, exciter, and power supply should be available in a convenient location to serve as an emergency replacement unit in case of a component failure.

SYSTEMS DEVELOPMENT

PIT Tag Injection Devices

Introduction

PIT tags are presently injected into fish with a modified hypodermic syringe and needle. Each injector is loaded by hand, requiring a tag to be manually inserted into the needle. This procedure was satisfactory for small numbers of fish. However, as greater numbers of fish are tagged? a more efficient means of placing the tag in the needle is required. 
Methods and Materials

A prototype injection system meeting the aforementioned requirement was designed (Fig. 28). The injector is mounted on a table, and a fish to be tagged is posit ioned on the tagging needle in an orientation similar to that used for the hand operated syringe tag injector (described in Appendix A). After positioning the fish on the needle, a foot operated switch is depressed which activates an air ram. Attached to the air ram is a plunger that pushes a tag through the needle and into the fish. After injecting the tag, the plunger retracts allowing a new tag to drop into position for the next tagging cycle. The tags are contained in a removable clfp that allows the tags to be gravity fed into the breech of the tagging machine. Each clip is preloaded with about 100 tags. The tagging system is designed to operate on AC power and bottled compressed air.

Results and Discussion

Refinements to the system are being made as testing of the system continues. Since the presentation of -the tagging needle to the fish is different using the new system, new tagging techniques are required and are being developed. Preliminary tests show that tag retention and fish survival were similar to that obtained with the hand held tag injector. The tagging rate using the new system is more than double that of the old system (i.e., up to 400 fish/h). Additional design work is being conducted to simplify loading the tag clips--this is now a time consuming task. The manufacturer of the tag has indicated they would be able to furnish tags preloaded in the clips once a final design of the system is achieved and the clips are furnished to them for loading. The new tagging system will be ready for field testing during the 1987 field season. 


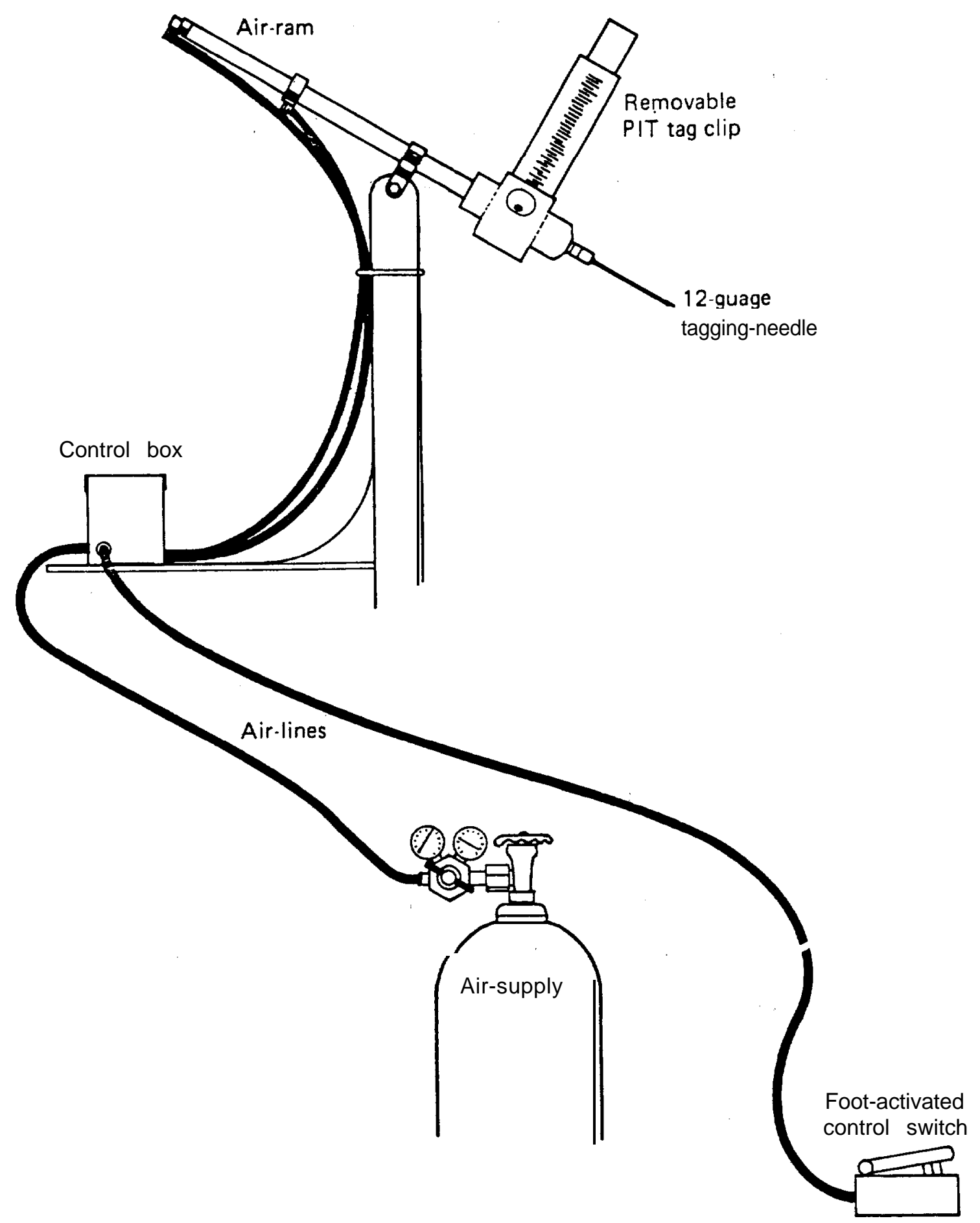

Figure 28.--Diagram of automatic PIT tag injector. 


\section{Quality Control Monitor For Tagging}

In 1986, an integrated system for PIT tagging fish, recording the tag code, and automatically recording length and weight of tagged fish (Fig. 29) was developed and tested under field conditions. This computer based system makes it possible to electronically maintain records on large numbers of individual fish. The system consists of' several components which are commercially available. ${ }^{2}$ A 150 - by $150-\mathrm{mm}$ rectangular table top PIT tag loop detector (Model 800-0102-00) is connected to a portable PIT tag detector (Model 800-0035-01). These two components are used to interrogate, decode, 'and transmit the tag code as a unique lo-digit hexadecimal number (e.g., 7F7E204A68, etc.) to a computer and printer for storage, Both components are manufactured by Identification Devices Inc. ${ }^{3}$ A sonic digitizing board (Model GP-7) 4 which uses triangulation is used to automatically record the length of each fish to the nearest $3 \mathrm{~mm}$. A plexiglass measuring board, constructed by NMFS is used to house the digitizer and to hold fish during the measurement procedure, An electronic balance (Model FY 3000$)^{5}$ is used to automatically record the weight of each fish to the nearest $0.5 \mathrm{~g}$.

The components of the tagging station are connected through a Bay Technical Associates multiport (Model 528$)^{6}$ to a Compaq dual floppy computer

2 Reference ot trade names does not imply endorsement by the National Marine Fisheries Service, NOAA.

3 Identification Devices Inc., 2545 Central Ave., Boulder, CO 80301.

4 Science Accessories Corporation, 970 Kings Highway West, Southport, Connecticut 06490

5 A \& D Engineering, Inc., 1555 McCandless Drive. Milpitas, CA 95035

6 Bay Technical Associates, Highway 603, PO Box 387, Bay Saint Louis, Mississippi 39520. 


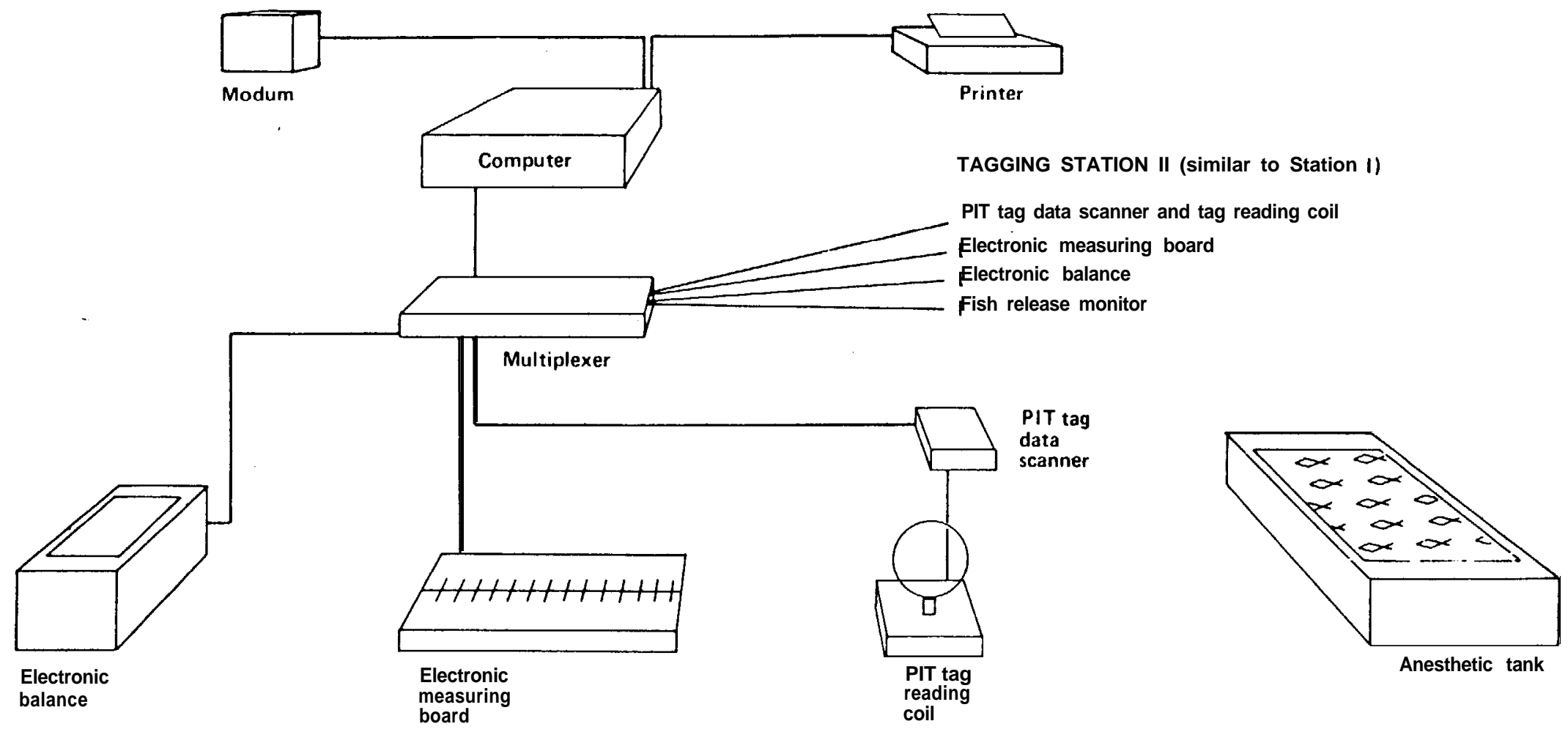

TAGGING STATION I

Figure 29.--Quality control monitor for PIT tagging. 
(Model 101709), 7 and an Epson (Model FX85) printer. ${ }^{8}$ The mult iport is used to direct the flow of information between the various components and the computer. The computer controls the operation of each component and storage of information. The printer provides hard copy of all data and acts as a secondary data backup in the event of an electronic failure.

An important part of the system is the computer program that controls information flow to and from the computer and from the various components of the system. The program, developed by NMFS, is written in Turbo Pascal and is public domain. ${ }^{9}$ The computer files are in ASCII (text) format.

Programs are available for either a single or double taging and documentation station. The single station requires only a computer to control data flow: however, the dual station requires additional computer terminals 10 to operate. In the dual station mode, each terminal is used for program initiation and control of a single tagging and documentation station. Either program enables the PIT tag to be read and recorded, length and weight information to be taken and documented, and comments about each animal to be recorded. These programs are menu driven and allow custom configuration (e.g., length or weight as optional or mandatory) which can be accessed at any time during the program operation. After all information on a fish has been obtained, the reading of

7 Compaq Computer Corp., 20555 FMl49, Houston, Texas 77070.

8 Epson America, Inc., 2780 Lomita Blvd., Torrance, California 90505.

9 The program was written by David Brastow of the Coastal Zone and Estuarine Studies Division, Northwest and Alaska Fisheries Center, National Marine Fisheries Service, National Oceanic and Atmospheric Administration, 2725 Montlake Boulevard East Seattle, Washington 98112.

10 Computer terminal Model wy-50 manufactured by Wyse Technology. San Jose, California. 
the next tag code causes the information to be accepted and recorded by the computer and a hard copy of the information printed.

The procedure for using the system requires several steps. First a fish is removed from an anest het ic tank and injected with a PIT tag as described in Appendix A. Tag injection can be done with either a hand held injector or with an automatic injector as described in Appendix A. While holding the fish in hand, the fish is passed through the tag detection loop. The tag code appears on the computer screen, and an audible tone is emitted by the data scanner (all information displayed on the computer screen is in an expanded format for ease of reading). The operator then places the fish on the digitizing board. The head of the fish is positioned against a stop which acts as a zero reference point. An electronic stylus is activated at the point where the measurement is to be taken. The length information in millimeters is displayed under the PIT tag code on the computer screen. In our studies, we measure the fork length of the fish. The accuracy of the digitizer operated under field conditions is $\pm 3 \mathrm{~mm}$. At this point, the fish may be weighed on the electronic balance, released into a holding container, or diverted to rearing area. If the fish is weighed, the accuracy of the measurement is within $\mathbf{0 . 5} \mathrm{g}$. The weight information appears on the computer screen under the tag code and length information. All information is automatically entered onto the computer and a printed hard copy is made when the next PIT-tagged fish is interrogated for its tag code. Tagging and documentation rate using the above (single station) system is in excess of $400 \mathrm{fish} / \mathrm{h}$. 
Hatchery Release Monitors

Introduction

Mortality and tag loss may occur between the time fish are tagged and released. Therefore, it is important to know the actual identification of each fish at the time of release so that tags that are no longer a part of the study can be eliminated from the data base.

Methods and Materials

Prentice et al. (1986) described a hatchery raceway release monitoring system that was tested at Dworshak National Fish Hatchery (DNFH) on 2 April and 7 May 1986. The monitor consisted of four pipes (measuring $10.2 \mathrm{~cm}$ in diameter by $61.0 \mathrm{~cm}$ long), each equipped with two PIT tag monitoring loops connected to tag monitoring equipment (Fig. 18). All of the monitors were connected to a computer and printer. The monitoring system was fitted to the exit of the raceway in a manner that forced all fish, tagged and non-tagged, through the monitor system. As PIT-tagged fish passed through a monitor, the tag number was recorded automatically on a computer file and printed. After the fish were released, the release file was compared to the file created at the time of tagging minus any already accounted for mortalities and tag losses. The comparison was done using R-base 5000 Microsoft program.

Results and Discussion

Each of the two raceways in which the monitoring system was tested contained about 40,000 fish. It required about 2 h to monitor all of the fish in a raceway. Two problems were encountered during the evaluation of the monitoring system. 
The first problem occurred during the first test (with spring chinook salmon) on 2 April 1986 at DNFH. The monitoring system was unable to process and record tags at a rate equal to the fish passage rate. The system would overload and stop reading tags for $3 \mathrm{~min}$ while it processed the tags in memory. After this period, the system would automatically start reading tags again until it again became overloaded. This problem was corrected with a software change by the equipment manufacturer--the new software was subsequently installed in all PIT tag monitoring systems. The problem was not observed during the second test (with steelhead) conducted on 7 May 1986 at DNFH using the new software.

The second problem, which occurred during both tests at DNFH, was that as fish were being released, the majority used only one or two of the four monitoring tubes available for exiting the raceway. In the future, steps must be taken to ensure uniform fish passage through the tag monitor system to increase reading efficiency and the rate fish exit the raceway.

Additional developmental work is planned to overcome problems with the present release monitor system before it can be used in production situations. New systems will be designed to monitor fish being loaded into transport trucks from hatchery ponds and raceways. These systems will be designed to be selfsupporting by having their own power supply. The fish will enter the monitor system by fish pumps or gravity. Initial evaluations of these systems are expected in 1987 .

Design and Placement of Future Monitoring Systems

In 1986, PIT tag monitoring systems designed to interrogate outmigrating juvenile salmonids were installed at Lower Granite Dam. In addition, the PIT tag interrogation system installed at McNary Dam in 1985 was redesigned and tested. The results of mechanical and biological testing conducted at both 
locations showed the systems to be reliable, accurate, and efficient. Based upon this information, we suggest that a juvenile monitoring system be installed at Little Goose Dam (Fig. 30) and adult monitoring systems be installed at Lower Granite Dam (Fig. 31). These additional systems are important if the PIT tag is to be used as an effective tool in answering the many questions pertaining to juvenile and adult salmonid fish passage through the Columbia River system.

\section{Conclusions and Recommendations}

1. The prototype automatic PIT tag injector system is satisfactory. However, additional design work (i.e., preloaded clips, etc.) is needed before this system can be used in production situations.

2. The integrated system for PIT tagging fish, recording the tag code, and automatically recording length and weight of tagged fish makes it possible to electronically maintain records on large numbers of individual fish.

3. The computer programs developed allow the operation of single or dual tagging and recording stations.

4. Additional development work is needed on hatchery release monitors before they are used in production situations.

5. We recommend that a release monitoring system be developed for use with fish pumps.

6. We recommend that a juvenile PIT tag monitoring system be installed at Little Goose Dam and an adult monitoring system be installed at Lower Granite Dam. 


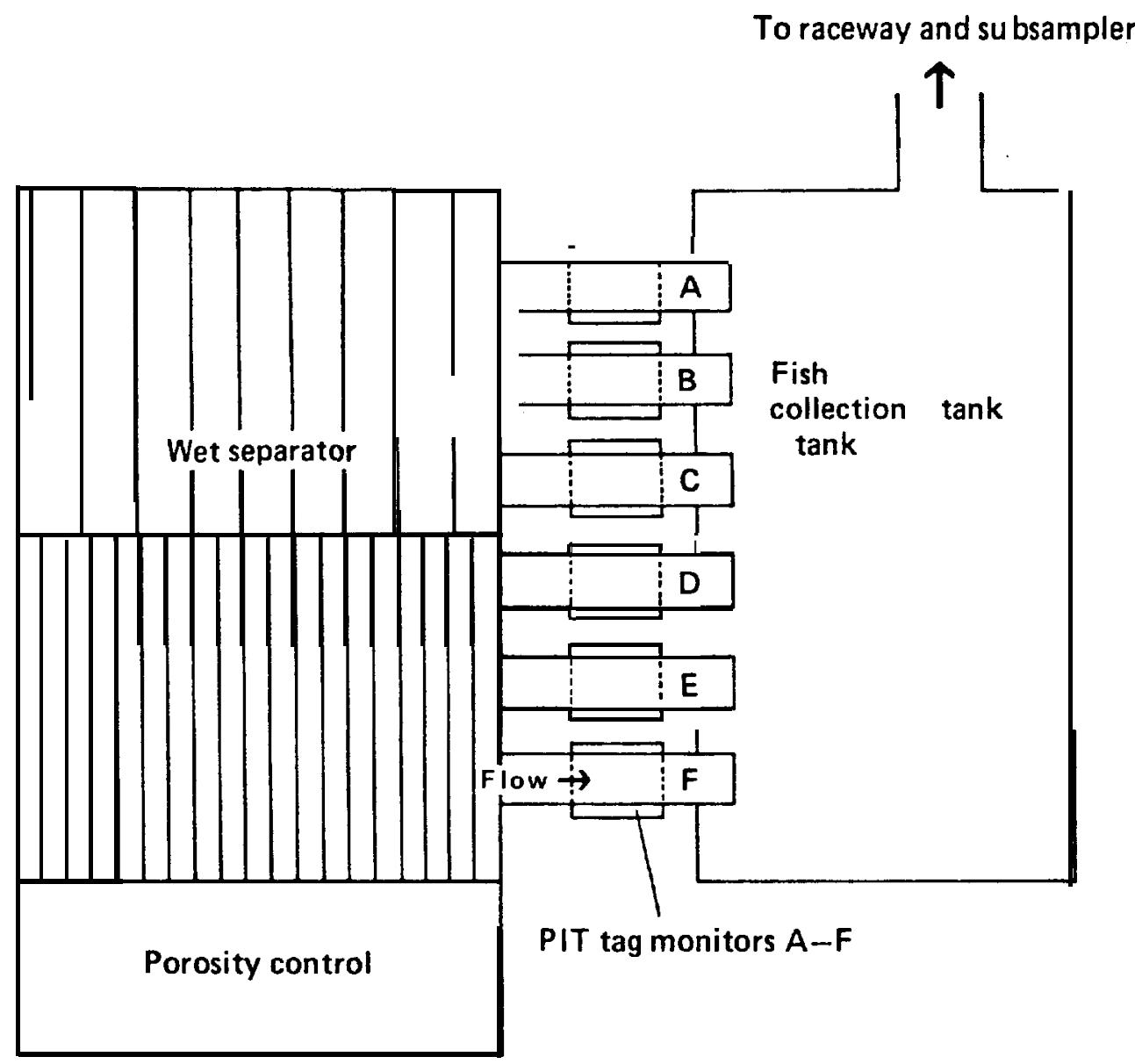

Figure 30.--Detection system design for Little Goose Dam juvenile PIT tag monitors, 1986. 


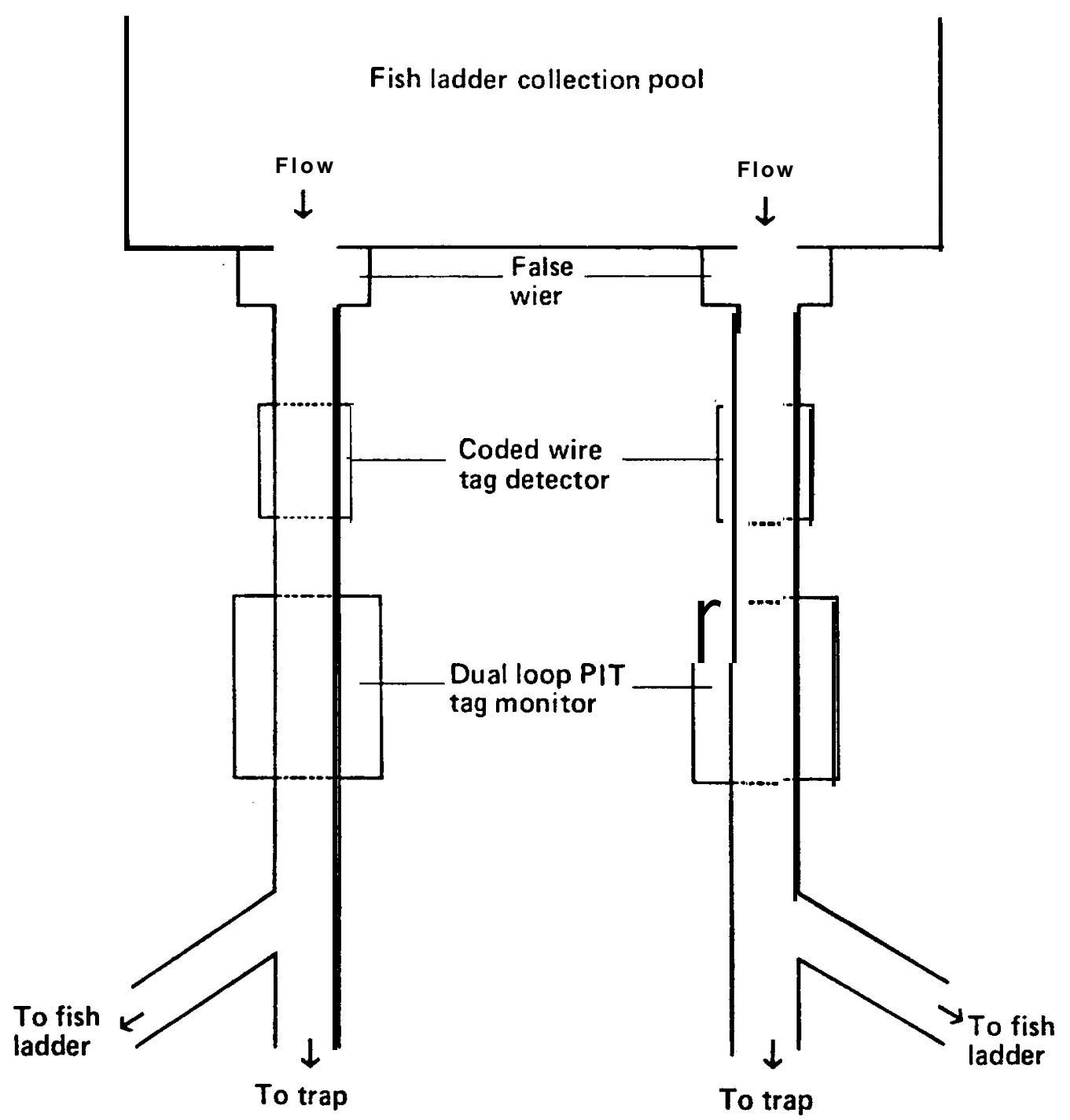

Figure 31 .--Detection system design for Lower Granite Dam adult PIT tag monitors, 1986. 
ACKNOWLEDGMENTS

Support for this research came from the region's electrical ratepayers through the Bonneville Power Administration.

Special thanks are given to David Cross for his technical support. We also thank Sarra Willis and Brad Eby of the U.S. Army Corps of Engineers and their crews, without their assistance the field studies could not have been conducted.

We are indebted to Dave Brastow for without his ability to develop computer programs and integrate key components the development of the PIT tag system may have been appreciably delayed.

In additional, we offer our appreciation to personnel of the Dworshak National Fish Hatchery, the Fish Passage Center, and the U. S. Fish and Wildlife Service (Fisheries Assistance office) for their assistance. 
LITERATURE CITED

Annon.

1987. Smolt monitoring annual report, 1986. Fish Passage Center, Portland, OR. $\quad 133 \mathrm{p}$. plus Appendixes (Report to Bonneville Power Administration, Project 86-60).

Beamish, F. W. H.

1978. Swimming capacity. In: W. S. Hoar and D. J. Randall, editors. Fish Physiology Volume 7. Academic Press Inc., New York, N.Y., p. 135.

Bell, W. H. and L. D. Terhune.

1970. Water tunnel design for fisheries research. Fish. Res. Board Can., Tech. Rep. 195:1-69.

Flagg, T. A.

1981. Swimming stamina and survival related to swimming fatigue 'in response to direct seaater entry during the Parr-smolt transformation of coho salmon. (Qncorhynchus kistuch) M. Sci. Thesis., University of Washington. $58 \mathrm{PP}$.

Flagg, T. A. and L. S. Smith.

1982. Changes in swimming behavior and stamina during smolting of coho salmon. Salmon and Trout Migratory Behavior Symposium. E. L. Brannon and E. 0. Salo, editors. June 1981. University of Washington press. p. 191-195. 
Flagg, T. A., E. F. Prentice, and L. S. Smith.

1983. Swimming stamina and survival following direct seawater entry during Parr-smolt transformation of coho salmon (Oncorhynchus kisutch). Aquaculture 32:383-396.

Kappenman, R. F.

1983. On the inferential use of predictive sample reuse. Commun. in Stat. Vol. 12, pp. 363-380.

Lewis, A. E., and W. R. A. Muntz.

1984. The effects of external ultrasonic tagging on the swimming performance of rainbow trout, Salmo gairdneri Richardson. J. Fish. Biol. 25:577-585.

Maule, A. G., C. B. Schreck, and S. L. Kaattari.

1987. Changes in the immune system of coho salmon (Oncorhynchus kisutch) during the Parr-to-smolt transformation and after implantation of cortisol. Can. J. Fish. Aquat. Sci. 44:161-166.

McCleave, J. D. and K. A. Stred.

1975. Effects of dummy transmitters on stamina of Atlantic salmon (Salmo salar) smolts. J. Fish. Res. Board Can. 32:599-563.

Park, Donn L. and Wesley J. Ebel.

1974. Marking fishes and invertebrates. II. Brand size and configuration in relation to long-term retention on steelhead trout and chinook salmon. Mar. Fish. Rev., Vol. 36, No. 7. pp. 1-6. 
Prentice, E. P., D. L. Park, and C. W. Sims.

1984. A study to determine the biological feasibility of a new fish tagging system. U.S. Dep. of Commer., Natl. Oceanic and Atmos. Admin., Natl. Marine Fish. Serv., Northwest and Alaska Fish. Cent., Seattle, WA. $38 \mathrm{p}$. (Report to Bonneville Power Administration, Contract DE-179-83BP11982, Project 83-19).

Prentice, E. P., C. W. Sims, and D. L. Park.

1985. A study to determine the biological feasibility of a new fish tagging system. U.S. Dep. of Commer., Natl. Oceanic and Atmos. Admin., Natl. Marine Fish. Serv., Northwest and Alaska Fish. Cent., Seattle, WA. $\quad 36 \mathrm{p}$. plus Appendixes (Report to Bonneville Power Administration, Contract DE-179-83BP11982, Project 83-19).

Prentice, E. P., D. L. Park, T. A. Flagg, and C. S. McCutcheon.

1986. A study to determine the biological feasibility of a new fish tagging system. U.S. Dep. of Commer., Natl. Oceanic and Atmos. Admin., Natl. Marine Fish. Serv., Northwest and Alaska Fish. Cent., Seattle, WA. $\quad 79 \mathrm{p}$. plus Appendixes (Report to Bonneville Power Administration, Contract DE-179-83BP11982, Project 83-19).

Raymond, H. L.

1974. Marking fishes and invertebrates. I. State of the art of fish branding. Mar. Fish. Rev. Vol. 36, No. 7. pp. 1-9. 
Smith; L. S., and T. W. Newcomb.

1970. A modified version of the Blaska respirometer and exercise chamber for large fish, J. Fish. Res. Board Can. 27:1331-1336.

Sokal, R. R., and F. J. Rohfl.

1981. Biometry. W. H. Freeman and Co., San Francisco, Calif.

Stevens, E. D.

1979. The effects of temperature on tailbeat frequency of fish swimming at a constant velocity. Can. J. 2001. 57:1628-1635.

Swan, G. A., and W. T. Norman

1987. Research to improve sub-yearling chinook salmon fish guiding efficiency at McNary Dam, 1986. U.S. Dep. of Commer., Natl. Oceanic and Atmos. Admin., Natl. Marine Fish. Serv., Northwest and Alaska Fish. Cent., Seattle, WA. 22 p. plus Appendixes (Report to U.S. Army Corps of Engineers, Contract DACW68-84-H-0034) . 
APPENDIX A

PIT Tagging Technique 
Laboratory tests (using sham tags) were conducted during 1984 to develop tag procedures and determine the most acceptable anatomical area for tag placement The body cavity was selected as the best area from both a biological and social standpoint (Prentice et al. 1985). Research during 1985 confirmed the selection of the body cavity as an acceptable site to implant the PIT tag and tagging technique was refined (Prentice et al. 1986). In 1986, the following fish handling and PIT tagging guidelines were developed (all studies in the present report generally follow these established procedures): the fish should be in good health with no signs of a disease outbreak; feeding should be stopped 2 days prior to tagging; all fish should be anesthetized for tagging; and after tagging, fish should be placed on maintenance ration for 3 days so that the gut does not expand and possibly dislodge the tag.

At tagging, the needle insertion for fish less than 200 grams is posterior of the pectoral fins and just off-set from the mid-ventral line. On larger fish the insertion location is anterior of the pelvic girdle and adjacent to the mid-ventral line. The bevel of the needle should be face up with the syringe at an angle between 20 and 45 degrees (to reduce sliding on the scales) depending on fish size (less angle for smaller fish). The needle pressure exerted should be held to a minimum, allowing just enough pressure to penetrate the body wall. Once the needle passes through the musculature, the syringe angle is decreased so the barrel of the needle parallels the body wall. The needle is then inserted to place the tag posterior to the pyloric caeca in the proximity of the pelvic girdle.

An antibiotic/petroleum jelly compound was init ially used to help hold the tag within the bore of the tagging needle. However! the adhesiveness of this compound caused the tag to remain on the tip of the needle and not be inserted properly. The tagging technique was modified by eliminating the compound and/or 
replacing it with ethanol. Presently, the tags and needles are disinfected using 60-90\% ethanol, with a minimum of 3-min exposure. In addition, all tagging equipment is disinfected periodically during the day and when moved from site to site.

After tagging, tag presence and code identity (individual ten digit alpha-numeric code) are obtained using a detector/decoding system. The system can be a portable (battery powered) hand held unit or a computer interfaced detection system. Computer interfaced detection stations are normally used and allow automated entry of tag code, length, weight, and other comments. These data files are assigned to the individual tag code as discrete units of information. 


\section{LITERATURE CITED}

Prentice, E. P., C. W. Sims, and D. L. Park.

1985. A study to determine the biological feasibility of a new fish tagging system. U.S. Dep. of Commer., Natl. Oceanic and Atmos. Admin., Natl. Marine Fish. Serv., Northwest and Alaska Fish. Cent., Seattle, WA. $\quad 36 \mathrm{p}$. plus Appendixes (Report to Bonneville Power Administration, Contract DE-179-83BP11982, Project 83-19).

Prentice, E. P., D. L. Park, T. A. Flagg, and C. S. McCutcheon.

1986. A study to determine the biological feasibility of a new fish tagging system. U.S. Dep. of Commer-, Natl. Oceanic and Atmos. Admin., Natl. Marine Fish. Serv., Northwest and Alaska Fish. Cent., Seattle, WA. $\quad 79 \mathrm{p}$. plus Appendixes (Report to Bonneville Power Administration, Contract DE-179-83BP11982, Project' 83-19). 
APPENDIX B

Histological Effects of the PIT Tag 
The insertion of a foreign body (e.g., internal or external tag) into a fish is a trauma which has the potential to initiate adverse host reaction [e.g., inflammation, melanomacrophage aggregation, encapsulation (adhesion) and/or rejection]. Information concerning the histological effects of different types of fish tags is not readily available. However, the effects of external (streamer type) tags have been documented and in most cases the tagging wound appears to heal normally in juvenile fish (Roberts et al. 1973a). Even so, it has been shown that streamer tags may initiate chronic lesions which can persist to adulthood (Roberts et al. 1973b).

The present study was initiated to examine host response after tagging juvenile salmonids with PIT tags. The PIT-tagged populations were observed through time, and wound healing was empirically quantified. In addition, serial samples were examined to document (histologically) the effects to the tissue from the tagging wound.

Preliminary (unpublished) histological observations on fish tagged with the polypropylene version of the PIT tag indicated that the tag did not initiate a severe host response. However, melanomacrophage aggregations in the peritoneal cavity and occasional tissue adhesions to the tag were observed, indicating that the fish recognized the tag as a foreign body. In addition, observations of wound healing with the polypropylene version of the PIT tag indicated that for smaller fish $(3-5 \mathrm{~g})$ up to $15 \%$ of the population might require over 1 month to completely heal (Prentice et al. 1986).

In 1986, the PIT tag was encapsulated in glass and tested in fish. Histological response and wound healing evaluations were conducted for this version of the PIT tag. A test group of fall chinook salmon (3.7 9 average weight) was established at Big Beef Creek on 14 April 1986. The 161 fish were PIT tagged and held in 1.2-m diameter tanks supplied with constant temperature 
$\left(10^{\circ} \mathrm{C}\right)$ well water. PIT tagging procedures followed the methods described in Appendix A.

During 1986, 30 PIT-tagged (glass encapsulated) fish were examined histologically by the pathology laboratory at the NMFS, Marine Experimental Station near Manchester, Washington. Fish were randomly subsampled and removed from the population at Days 22, 30, and 45 post tagging (Fig. Bl). Tissues from 10 fish at each sampling date were embedded in paraffin, sectioned at 6 microns, and stained with hematoxylin and eosin for histological evaluation.

On Day 22 after tagging, the injection site for all fish examined consisted of granulation tissue (fibroblast) which had replaced the dermis and underlying muscle tissue damaged during injection of the tag (Figs. B2 and B3). Peritoneal and epidermal tissue were regenerated by this time indicating that normal and timely healing had occurred. At 30 and $45 \mathrm{~d}$ after tagging, the injection site was difficult to locate histologically (probably due to regeneration and contraction of tissue at the injection site) indicating that for all fish examined complete healing had occurred.

No host reaction to the tag was observed for any of the fish examined at either Days 22, 30, or 45. Neither melanomachrophage accumulations nor tissue adhesions were noted, suggesting that the fish did not recognize the tag as a foreign body. The glass-encapsulated tag appears to be functionally biologically inert.

PIT tag wound condition was empirically evaluated for the remaining 10 groups of fish between Days 14 and 45 post tagging (Fig. Bl). All fish examined $(\mathrm{n}=120)$ showed the tag wound to be completely healed (Table Bl). Even as early as Day 14 post tagging, there was little evidence of scar tissue, and by Day 30, the epidermal pigmentation appeared normal in coloration. This supports the histological evidence and indicates a lack of continuing trauma from the tagging 
SAMPLING PLAN -1986

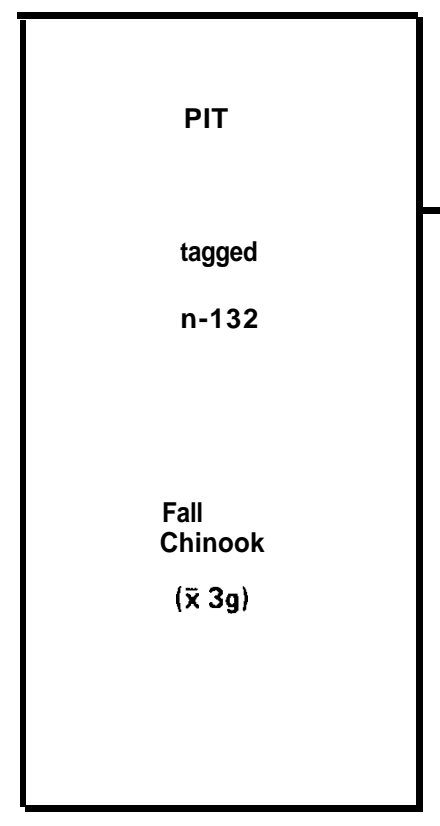

Tag location and injection site condition

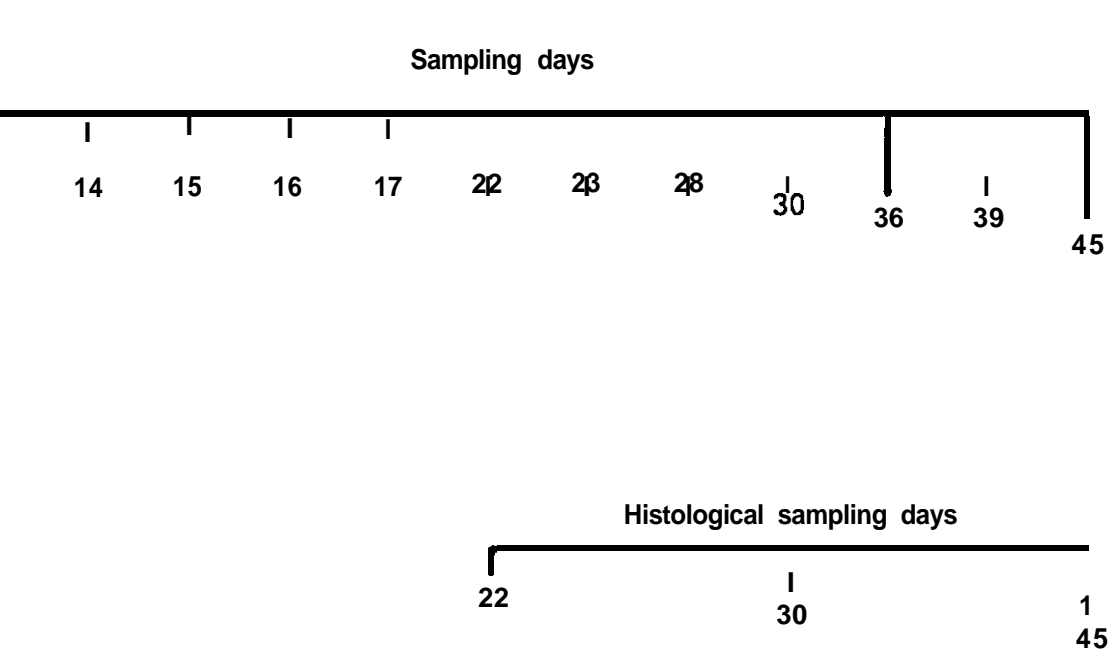

Appendix Figure B1.--Sampling schedule for histological and would healing evaluation for PIT-tagged fall chinook salmon, 1986. 


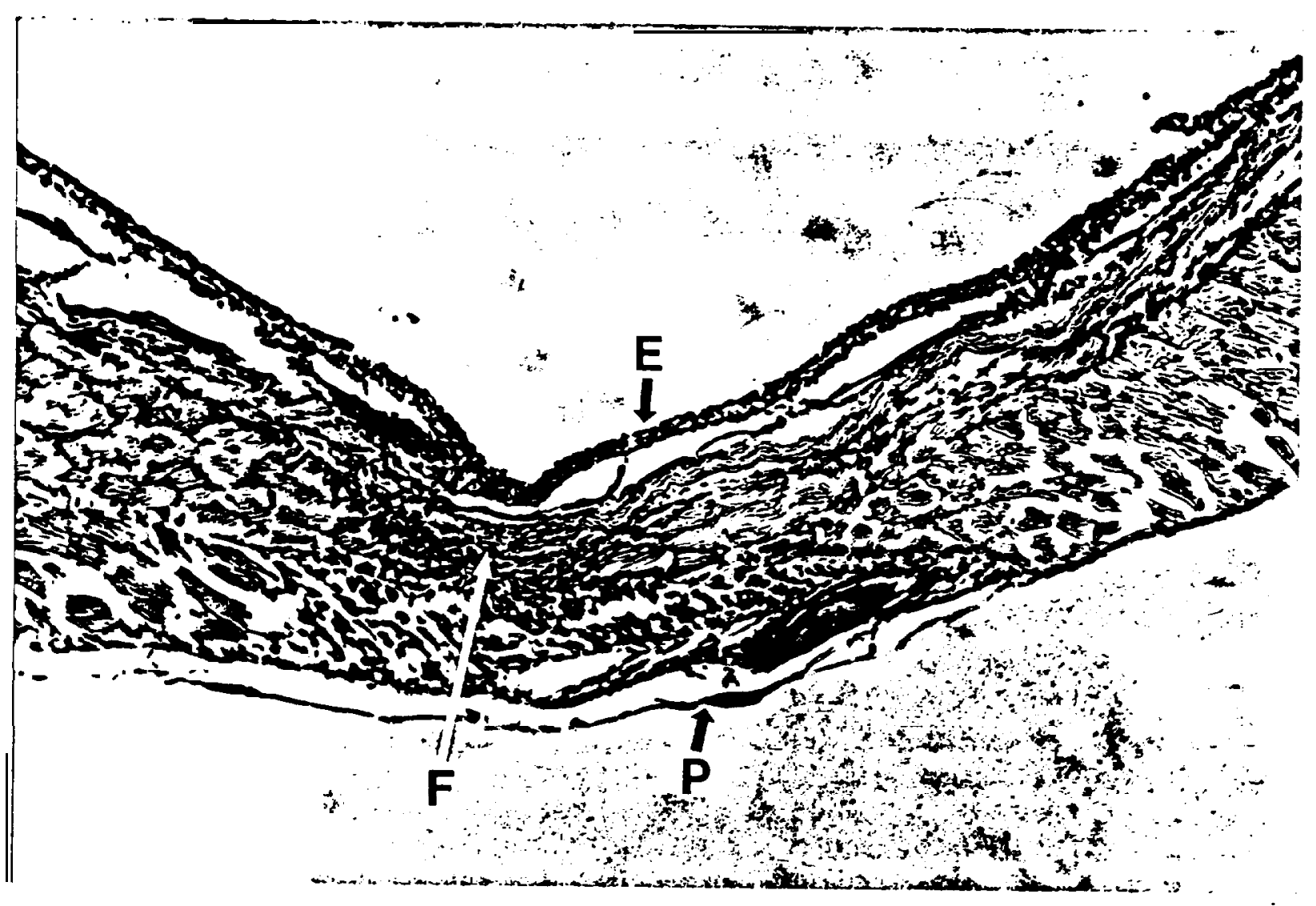

Appendix Figure B2.--Completely healed injection site at 21 days post tagging. Epidermis--E, fibrocytic infiltration--F, and peritoneum-P. 


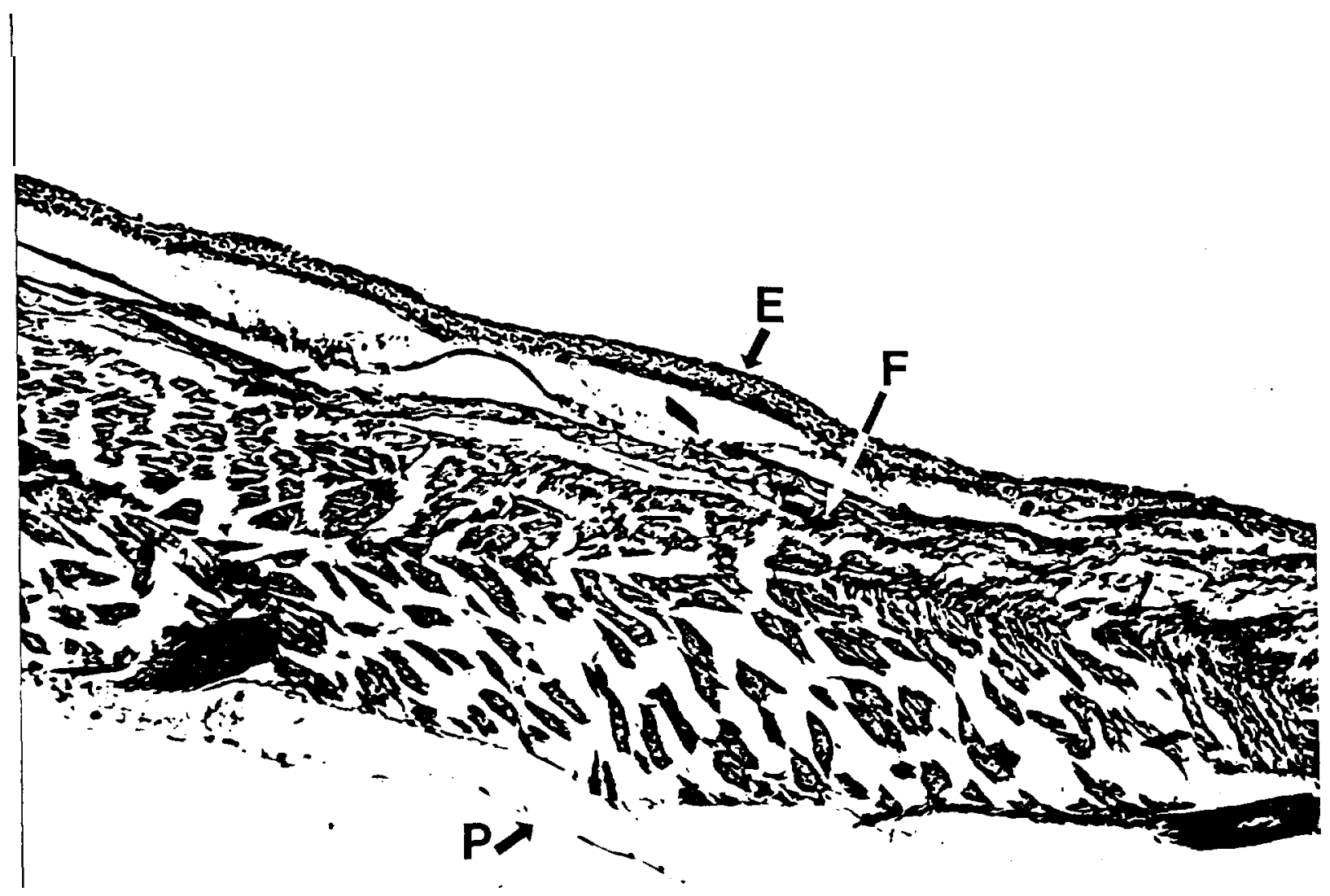

Appendix Figure B3.--Normal integument. Epidermis--E, fibrocytic
infiltration--F, and peritoneum--P. 
Appendix Table BI.--Summary of wound condit'on after tagging and tag location within the body cavity of juvenile fall chinook salmon over time with a description of wound condition and tag location.

\begin{tabular}{|c|c|c|c|c|c|c|c|c|c|c|}
\hline \multirow[b]{2}{*}{ Code } & \multicolumn{2}{|c|}{ Percent 0} & sh_ & Ln & ass: & & ade & dav: & st & Lng \\
\hline & 14 & 15 & 16 & 22 & 23 & 28 & 30 & 36 & 39 & 45 \\
\hline
\end{tabular}

Wound $\mathbf{a}$

$\begin{array}{rrrrrrrrrrr}A & 0 & 0 & 0 & 0 & 0 & 0 & 0 & 0 & 0 & 0 \\ B & 0 & 0 & 0 & 0 & 0 & 0 & 0 & 0 & 0 & 0 \\ C & 100 & 100 & 100 & 100 & 100 & 100 & 100 & 100 & 100 & 100\end{array}$

Tag location b

\begin{tabular}{|c|c|c|c|c|c|c|c|c|c|c|}
\hline A & 0 & 0 & 0 & tx & 0 & 0 & $*$ & 0 & 0 & $*$ \\
\hline B & 91.7 & 100 & 100 & --- & 100 & 92.8 & $-\cdots$ & 100 & 100 & $\ldots$ \\
\hline C & 8.3 & 0 & 0 & --- & 0 & 7.2 & --- & 0 & 0 & $\cdots$ \\
\hline D & 0 & 0 & 0 & -- & 0 & 0 & --- & 0 & 0 & $\cdots$ \\
\hline E & 0 & 0 & 0 & --- & 0 & 0 & -- & 0 & 0 & $\cdots$ \\
\hline F & 0 & 0 & 0 & --- & 0 & 0 & --- & 0 & 0 & $\cdots$ \\
\hline
\end{tabular}

9, = Fish preserved for histological examination.

a $A=A n$ open wound.

$B=A$ wound that is closed by a thin membrane and is healing-- at times a slight red or pinkish coloration is noticeable in the area of the wound.

$\mathrm{C}=\mathrm{A}$ wound completely healed and may or may not be noticeable due to presence of a scar. There is no red or pink coloration in the area of the wound.

b $\mathbf{A}=$ Tag located between the pyloric caeca and mid-gut.

B - Tag located near abdominal musculature and often embedded in the posterior area of pyloric caeca near the spleen or in the adipose tissue at the posterior area of the pyloric caeca.

$\mathrm{C}=$ Tag found in an area other than those noted-- generally between the mid-gut and air bladder or between the liver and pyloric caeca.

$D=$ Notag present.

$E$ = Tag partially protruding through abdominal wall. 
wound. It appears that the present tagging procedures should allow complete healing within 2 weeks post tagging.

Tag placement within the body cavity was consistent for all sample groups. Tag retention was $100 \%$ during this study, and the majority of the tags $(98.8 \%$ overall) were observed near the abdominal musculature in the posterior area of the pyloric caeca near the spleen. The remaining 1-2\% of the tags were generally located between the mid-gut and the pyloric caeca (Table B1). All tags were found to be "free floating" with no tissue adhesion noted. Since tag location was consistent between sampling periods, there appears to be no potential migration of the tag within the body cavity. The tag location results noted during this study are consistent with those obtained in earlier studies (Prentice et al. 1985, 1986) and indicate that a uniform, repeatable tagging technique has been developed. 
Prentice, E. P., D. L. Park, T. A. Flagg, and C. S. McCutcheon.

1986. A study to determine the biological feasibility of a new fish tagging system. U.S. Dep. of Commer., Nat1.Oceanic and Atmos. Admin., Natl.Marine Fish. Serv., Northwest and Alaska Fish. Cent., Seattle, WA. $\quad 79 \mathrm{p}$. plus Appendixes (Report to Bonneville Power Administration, Contract DE-179-83BP11982, Project 83-19).

Roberts, R. J., A. MacQueen, W. M. Shearer, and H. Young.

1973a. The histopathology of salmon tagging. I. The tagging lesion in newly tagged parr. J. Fish. Biol. 5:497-503.

1973b. The histopathology of salmon tagging. II. The chronic tagging lesion in returning adult fish. J. Fish. Biol. 5:615-619. 
APPENDIX C

Budget Information 
A. Summary of expenditures

Personnel Services and Beniffts

$\$ 176 \cdot 5 K$

Travel and Transportation of Persons

$11.8 \mathrm{~K}$

Transportation of Things

$7 \cdot 2 \mathrm{~K}$

Rents, Communications, \& Utilities

$7.6 \mathrm{~K}$

Printing and Reproduction

$0.3 \mathrm{~K}$

Contract and Other Services

$3 \cdot 3 \mathrm{~K}$

Supplies and Materials

$208.4 K$

Equipment

$29.7 \mathrm{~K}$

Grants

0

Support Cost (Including DOC ovhd.)

77.48

TOTAL

$\$ 522 \cdot 2 \mathrm{~K}$

B. Major items purchased

1. PIT tag monitoring system for juvenile migrants at Little Goose Dam-Contract 50ABNF600048-Amendment I.

2. Design and engineering for revisions and upgrading of PIT tag monitoring equipment at three dams--Contract 50ABNF600048-Amendment II.

3. PIT tag monitoring system for adult migrants at Lower Granite Dam-Contract 50ABNF600048-Amendment III.

The following sensitive items were purchased:

1. Three compaq portable computers with dual floppy drives, a 20MG hard drive, 640K memory, math coprocessor, and built-in modems.

2. One compaq portable computer with dual floppy drive, math coprocessor, 640K memory, and built-in modem. 